\title{
AVALIAÇÃO DE DESINFETANTES DE USO GERAL QUANTO À EMISSÃO DE FORMALDEÍDO
}

\author{
VERA LÚCIA SIQUEIRA PETILLO
}

TESE DE DOUTORADO APRESENTADA AO DEPARTAMENTO DE SAÚDE AMBIENTAL DA FACULDADE DE SAÚDE PÚBLICA DA UNIVERSIDADE DE SÃO PAULO PARA A OBTENÇÃO DO GRAU DE DOUTOR EM SAÚDE PÚBLICA.

ÁREA DE CONCENTRAÇÃO: SAÚDE AMBIENTAL. ORIENTADOR: PROF. DR. ARLINDO PHILIPPI JR.

SÃO PAULO

2002 
Autorizo, exclusivamente para fins acadêmicos e científicos, a reprodução total ou parcial desta tese, por processos fotocopiadores.

Assinatura:

Data: 11.11 .2002 
Aos meus familiares e amigos, em especial ao meu filho Gabriel. 


\section{AGRADECIMENTOS}

Agradeço sinceramente esta realização à Deus, à toda minha família, à todos os meus mestres da Faculdade de Saúde Pública da USP, da Universidade Mackenzie e do Instituto de Química da USP, aos meus amigos químicos e sanitaristas, meus colegas de Pesquisa \& Desenvolvimento da Fundacentro, Unilever e Lonza do Brasil Ltda bem como à todos aqueles, que me apoiaram e, de alguma forma, contribuiram para a realização desse trabalho.

Agradeço particularmente a determinação e o sonho dos meus pais Apfia e Marcílio, o apoio da minha irmã Regina e das amigas Rita e Simone, a compreensão do meu esposo Carlos Alberto e a ajuda do meu cunhado Samuel.

Agradeço especialmente a confiança do orientador Prof. Dr. Artindo, a colaboração do co-orientador Prof. Dr. João Vicente Assunção, o incentivo do Prof. Regis Nieto da Universidade Mackenzie, dos colegas Francisco Kulczar Neto da Fundacentro, Wilson Hatanaka da WWHATA Consultoria e dos colegas da Brasindoor, Prof. Dr. Luiz Fernando de Goes Siqueira, Prof. Dr. Francisco Radler de Aquino Neto e Marcelo Gurgel, bem como a ajuda do Dr. Ted Lange - Montana State University Extention Service e dos membros da USEPA: Dr. Jim Darr - Pollution Prevention Division e Dr. Bruce Henschel - National Risk Management Research Laboratory.

Agradeço carinhosamente 0 apoio diário das companheiras Aurora e Marluce sem o qual este trabalho não estaria concluído. 


\section{RESUMO}

Petillo, VLS. Avaliação de desinfetantes de uso geral quanto à emissão de formaldeído. São Paulo; 2002. [Tese de Doutorado - Faculdade de Saúde Pública da USP].

Objetivo. Avaliar desinfetantes de uso geral quanto à emissão de formaldeído, um composto orgânico volátil (COV), altamente irritante e classificado no grupo 2A do IARC como provavelmente carcinogênico para humanos. Métodos. Após a seleção do formaldeído como o COV mais tóxico e comum da composição de desinfetantes, através dos dados e informações de rótulo e literatura, prodedeu-se à determinação da sua concentração nos produtos, amostragem e medição no ar durante e após a desinfecção de sanitários com produto puro, e análise da legislação brasileira quanto à regulamentação de produtos de limpeza bem como ao controle da Qualidade do Ar Interior. Resultados. O formaldeído foi identificado nos 17 produtos coletados nas concentrações de 0,1 a 2,2\% para 16 deles. Um desinfetante apresentou $7,5 \% \mathrm{p} / \mathrm{p}$, resultando em $49 \mathrm{mg} / \mathrm{m}^{3}$ no ar $\left(25^{\circ} \mathrm{C}, 760 \mathrm{mmHg}\right)$, tendo sido necessário usar proteção respiratória. A concentração no ar durante os 15 minutos iniciais para 0 produto contendo $0,6 \%$ foi $0,47 \mathrm{mg} / \mathrm{m}^{3}$, portanto acima do limite de exposição médio de $0,37 \mathrm{mg} / \mathrm{m}^{3}$ (ACGIH/EUA) e do nível de efeito não observado (NOEL) de $0,25 \mathrm{mg} / \mathrm{m}^{3}$ (IARC). Conclusões. Desinfetantes de uso geral contendo formaldeído podem apresentar riscos à saúde. Recomenda-se retirar o formaldeído da lista de substâncias de ação antimicrobiana autorizadas da Portaria MS № 15/1988 compatibilizando-a com a Resolução MS № 176/2000 e definir limites de concentração de COVs totais p/p por categoria de produto. Foi apresentada uma proposta para a criação de um projeto de Prevenção da Poluição do Ar Interior de abrangência nacional.

Descritores: Saúde Ambiental. Gestão Ambiental. Qualidade do Ar Interior. Prevenção da Poluição do Ar Interior. Produto de Limpeza. Gerenciamento de Risco. 


\section{SUMMARY}

Petillo, VLS. Assessment of general-purpose disinfectants with regards to the emission of formaldehyde. São Paulo; 2002. [Doctorate Thesis Faculdade de Saúde Pública - Universidade de São Paulo].

Objective. To assess general-purpose disinfectants with regards to their emission of formaldehyde, a volatile organic compound (VOC), extremely irritant and classified in group 2A of IARC as probably carcinogenic to humans. Methods. Formaldehyde was selected as the most often occurring and toxic ingredient of the disinfectants compositions from the data and information present on the labels and in literature; concentration in the products and in air sampled during and after use of undiluted products in toilettes were determined. Brazilian legislation regarding the regulatory requirements for cleaning products and the Indoor Air Quality control was analyzed. Results. Formaldehyde has been identified in the 17 collected products at levels between 0.1 to $2.2 \%$ but one product contained $7.5 \%$, resulting in $49 \mathrm{mg} / \mathrm{m}^{3}\left(25^{\circ} \mathrm{C}, 760 \mathrm{mmHg}\right)$ therefore respiratory protection was required. The concentration in the air during the first 15 minutes after use of the product containing $0.6 \%$ was $0.47 \mathrm{mg} / \mathrm{m}^{3}$. This is higher than the permitted time-weighted average exposure level of $0.37 \mathrm{mg} / \mathrm{m}^{3}$ (ACGIH/EUA) and the no observed effect level (NOEL) of $0.25 \mathrm{mg} / \mathrm{m}^{3}$ (IARC). Conclusions. Some disinfectants containing formaldehyde present risks to health. The recommendations are to remove the formaldehyde from the list of anti-microbial substances of the Standard MS 15/1988 accordingly with the Standard MS 176/2000 and to define limits of total VOC for each category of cleaning product. A proposal was presented to create a project for Indoor Air Pollution Prevention with a nation wide scope.

Descriptors: Environmental Health. Environmental Management. Indoor Air Quality. Indoor Air Pollution Prevention. Cleaning Product. Risk Management. 


\section{ABREVIATURAS UTILIZADAS}

ABIPLA

ABNT

ABRALIMP

ACGIH

ANVISA

BPF

BRASINDOOR
Associação Brasileira de Produtos de Limpeza e Afins. Associação Brasileira de Normas Técnicas.

Associação Brasileira do Mercado Institucional de Limpeza.

American Conference of Governmental Industrial Hygienists. Conferência Americana de Higienistas Ocupacionais Governamentais localizado em Ohio. É uma organização de pessoas atuando profissionalmente em instituições educacionais governamentais ou engajadas em programas de segurança e saúde ocupacional. A ACGIH desenvolve e publica limites recomendados de exposição ocupacional para centenas de substâncias químicas e agentes físicos.

Agência Nacional da Vigilância Sanitária. Ministério da Saúde.

Boas Práticas de Fabricação. Práticas higiênicas de fabricação. Procedimentos e práticas que visam a padronização e definição de procedimentos, métodos de fabricação, condições de instalaçōes de uma empresa, equipamentos e respectivas manutenções, critérios de segurança, bem como matérias-primas, embalagens, condições de estocagem e aspectos relativos ao meio ambiente, para garantir a qualidade e a segurança no uso dos produtos saneantes domissanitários (Ministério da Saúde, 1997).

Sociedade Brasileira de Meio Ambiente e Controle da Qualidade do Ar de Interiores. 
Chemical Abstract Service. Uma divisão da American Chemical Society. Os números CAS são usados para identificar substâncias ou produtos químicos especificos.

CIIT Chemical Industry Institute of Toxicology.

$\mathrm{CCIH}$ Comissão de Controle de Infecção Hospitalar.

$\mathrm{CL}_{50}$ Concentração Letal mediana de um agente, que mata $50 \%$ da população de animais de prova no grupo normalizado em um certo tempo de exposição e de observação subsequente, expressa em $\mathrm{mg}$ de produto por volume em litros do ar ambiente em teste.

CG Cromatografia Gasosa.

COAV Compostos Orgânicos Altamente Voláteis.

CONAMA Conselho Nacional do Meio Ambiente.

COV Composto Orgânico Volátil.

$\mathrm{DL}_{50}$ Dose Letal Mediana. (Median Lethal Dose $-L_{50}$ ). $O$ valor $D_{50}$ é um cálculo estatístico do número de miligramas de um dado material por quilo de peso corpóreo para matar $50 \%$ da população de animais de prova sob um conjunto definido de condiçōes experimentais.

DNA Deoxyribonucleic Acid.

DNFH (DNPH). Dinitrofenilhidrazina ou 2,4dinitrofenilhidrazina (2,4-DNFH). Reagente especifico para formaldeído. Cartuchos ou tubos contendo silicagel impregnada com DNFH são utilizados para amostragem de formaldeído no ar. O formaldeído é então separado e analizado por HPLC. Ver HPLC. 
FAPESP

Fundação de Amparo à Pesquisa do Estado de São Paulo.

FDA Food and Drugs Administration.

FID Flame Ionization Detector.

FUNASA Fundação Nacional de Saúde.

GC Gas Chromatography.

HPLC

High Performace Liquid Cromatography. Cromatografia Líquida de Alta Performance (ou eficiência).

IARC International Agency for Research on Cancer. Agência Internacional parea a Pesquisa sobre Câncer.

MAI

Meio Ambiente Interior.

MAK

Maximale arbeitsplatzkonzentrationen. Legislação ocupacional alemã, apresenta indicações para limites de exposição de curta duração para quase todas as substâncias; bastante atualizada e bem fundamentada.

máx.

Máximo.

MS

Mass Spectroscopy. Detetor de Espectroscopia de Massa ou Ministério da Saúde.

MSDS

Material Safety Data Sheet. Folheto de dados e informações de segurança do material fornecidos pelo fabricante.

$\mathrm{NIOSH}$

National Institute for Occupational Safety and Health / USA. Instituto Nacional para a Segurança e Saúde Ocupacional dos EUA ligado ao Serviço de Saúde Pública do Ministério da Saúde e Serviços Humanos. Agência Federal Americana que recomenda limites de exposição ocupacional para várias substâncias e 
assiste a OSHA em investigações e pesquidsas em segurança e saúde ocupacional.

NOEL

No Observed Effect Level. Nivel de efeito não observado. A dose máxima ou concentração ambiental que um organismo pode tolerar durante um periodo de tempo específico sem mostrar nenhum efeito adverso ou sob a qual se detectem efeitos adversos. Dose na qual não se observam efeitos.

OECD Organization for Economic Co-operation and Development.

OMS Organização Mundial da Saúde.

OSHA Occupational Safety and Health Administration / USA. Administração de Segurança e Saúde Ocupacional. Agência federal norte-americana ligada ao Ministério do trabalho com autoridade regulamentar na área de segurança e saúde para a maioria das indústrias e comércios.

PEL

Permissible Exposure Limit. Limite de Exposição Ocupacional legal para contaminantes estabelecido pela OSHAVEUA, que indica a concentração permissivel de contaminantes no ar para a qual todos os trabalhadores podem ser repetidamente expostos durante 8 horas por dia, quarenta horas por semana, durante a vida ocupacional (30 anos) sem apresentar efeitos adversos à saúde.

PET

Polietileno tereftalato. Largamente utilizado na fabricação de embalagens principalmente para bebidas refrigerantes.

$\mathrm{pH}$

Potencial hidrogeniônico. A medida de acidez ou alcalinidade de uma solução química, variando de 0 a 
14. Ácidos têm pH menor que $7 \mathrm{e}$ bases (álcalis) têm $\mathrm{pH}$ maior que 7.

PPQAI

Prevenção da Poluição Química do Ar Interior.

QAI

Qualidade do Ar Interior.

RE

Resolução.

REBLAS

Rede Brasileira de Laboratórios capacitados a atender à execução das análises requeridas pela Agência Nacional da Vigilância Sanitária do Ministério da Saúde.

RMSP

Região Metropolitana de São Paulo.

SEBRAE

Serviço de apoio às Micro e Pequenas Empresas de São Paulo.

SED

Síndrome do Edifício Doente.

SINVAS

Sistema Nacional de Vigilância Ambiental em Saúde.

STEL

Short Term Exposure Limit. Trata-se de um limite instantâneo.

TLV

Threshold Limit Value.

TWA

Time-weighted Average.

UFC

Unidade Formadora de Colônia.

USEPA

United States Environmental Protection Agency.

VOC

Volatile Organic Compound.

WHO

World Health Organization. 


\section{UNIDADES UTILIZADAS}

$\mu g / m^{3}$

M

$\mathrm{mg} / \mathrm{L}$

$\mathrm{mg} / \mathrm{m}^{3}$

$\mathrm{m}^{3} / \mathrm{h}$

$\mathrm{mmHg}$

$\mathrm{Nm}$

$\mathrm{Pa}$

$\% \mathrm{p} / \mathrm{p}$

$\mathrm{ppb}$

ppm

$\mathrm{UFC} / \mathrm{m}^{3}$

Microgramas por metro cúbico. Unidade de concentração em massa por volume.

Molar. Unidade de concentração molar para soluções, expressa em moles por litro.

Miligramas por litro. Unidade de concentração em massa por volume.

Miligrama por metro cúbico. Unidade de concentração em massa por volume.

Metro cúbico por hora. Unidade de vazão em volume por tempo.

Milímetro de mercúrio. Unidade de pressão.

Nanômetro . Unidade de comprimento de onda.

Pascal. Unidade de pressão. Múltiplos: hPa, $\mathrm{kPa}$.

Porcentagem por peso ou peso/peso. Unidade de concentração.

Partes por bilhão. Unidade de concentração de partes do gás por bilhão $\left(10^{9}\right)$ partes da mistura ar-gás, normalmente expressas por volume (ppbv).

Partes por milhão. Unidade de concentração de um gás ou vapor no ar. Também é usada para indicar a concentração de uma determinada substância em um líquido ou sólido.

Unidades Formadoras de Colônia por metro cúbico. Unidade de concentração de microorganismos. Também se usa UFC/mL para líquidos. 


\section{LISTA DE TABELAS}

Pág.

Tabela 1 Participação de mercado das categorias de 16 produtos de limpeza doméstica

Tabela 2 Principais dados e informações declarados nos rótulos dos produtos

Tabela 3 Sistemas bactericidas declarados nos rótulos dos produtos

Tabela 4 Composição química dos sistemas bactericidas 66 declarados nos rótulos dos desinfetantes de uso geral e suas respectivas concentrações

Tabela 5 Concentração de formaldeído analisada nos desinfetantes de uso geral encontrados no grande varejo da RMSP

Tabela 6 Concentração total de formaldeído no ar, emitido 69 na desinfecção dos sanitários - Etapa 1

Tabela 7 Concentração de formaldeído no ar, emitido 71 durante e após a desinfecção dos sanitários Etapa 2 


\section{ÍNDICE}

Pág.

1 INTRODUÇÃO 1

1.1 Qualidade do Ar Interior e Saúde Ambiental 2

1.2 Sindrome do Edificio Doente 6

1.3 Poluição do ar interior e seu impacto sobre a Saúde 10

1.4 Compostos Orgânicos Voláteis e a Poluição Química do 13 Ar Interior

1.5 Uso de produtos saneantes domissanitários para 15 higienização de interiores

1.6 Produtos de limpeza e suas formulaçőes 21

1.6.1 Formulação e produção de desinfetantes 25

1.7 Propriedades físico-químicas dos compostos orgânicos 30 voláteis de ação antimicrobiana

1.7.1 Formaldeído 30

1.7.2 Derivados de fenol 31

1.7.3 Compostos quaternários de amônio 33

1.8 Perfil toxicológico do formaldeído 34

1.9 Aspectos da legislação sanitária brasileira $\quad 40$

1.9.1 Em relação à regulamentação de saneantes 40 domissanitários de ação antimicrobiana

1.9.2 Em relação ao controle da Qualidade do Ar Interior $\quad 42$

2 OBJETIVOS 45

3 MÉTODOS 46

3.1 Amostragem dos produtos no mercado $\quad 50$

3.2 Seleção do principal composto orgânico tóxico 52

3.3 Determinação de formaldeído nos produtos 52 
3.4 Método de amostragem de formaldeído

3.4.1 Definição das condições do ambiente $\quad 54$

3.4.2 Coleta das amostras $\quad 56$

3.5 Método de determinação de formaldeido por HPLC nas $\quad 57$ amostras ambientais

3.6 Método de análise de aspectos da legislação sanitária $\quad 60$

4 RESULTADOS E DISCUSSĀO 61

4.1 Dados e informaçōes declarados nos rótulos dos 61 produtos

4.1.1 Determinações de formaldeido nos produtos 66

4.1.2 Avaliações ambientais de formaldeído 68

4.2 Análise de aspectos da legislação sanitária 73

4.3 Iniciativas relacionadas à Prevenção da Poluição 75

Química do Ar Interior e a produtos de limpeza

5 CONCLUSÃO

5.1 Recomendaçōes 78

5.2 Proposta de criação do projeto de Prevenção da Poluição $\quad 79$ do Ar Interior

$\begin{array}{ll}5.3 \text { Análise das hipóteses } & 85\end{array}$

5.4. Perspectivas 86

6 REFERÉNCIAS $\quad 87$

7 ANEXOS 100

Anexo1 - Roteiro para formulação de desinfetantes

Anexo2 - Possiveis fontes de poluentes químicos

Anexo 3 - Arranjo físico e sistema de ventilação dos sanitários

GLOSSÁRIO 


\section{INTRODUÇÃO}

A questão da conservação do meio ambiente tem sido apontada nas grandes reuniões mundiais como o maior desafio da humanidade neste início de novo milênio. Na busca por instrumentos de gestão ambiental, normalmente voltados para a proteção do meio natural - solo, ar e água - a questão da qualidade do ambiente construído ou ambiente interior vem ganhando maior atenção devido à crescente urbanização.

A qualidade do ar que se respira nos ambientes construidos está se tornando um assunto de importância cada vez maior em Saúde Pública, pois as condições ambientais inadequadas, encontradas no interior dos edifícios, podem afetar a saúde, o bem-estar e o conforto dos seus ocupantes.

A proteção da saúde humana contra as ameaças de agentes etiológicos requer o controle da contaminação microbiológica em ambientes interiores, o que por sua vez, demanda o uso de produtos químicos para limpeza e desinfecção dos mais diversos tipos de superfície, seja em ambientes residenciais, institucionais ou industriais.

Os desinfetantes são produtos indispensáveis para a proteção da saúde humana, entretanto, a escolha incorreta e o mau uso dos produtos podem provocar, não só poluição biológica, quando não há eficácia antimicrobiana, como também poluição química do ar, quando são emitidas substâncias tóxicas, em outras palavras, compostos orgânicos voláteis (COVs), os quais são citados na literatura abreviadamente como VOC ou seja, volatile organic compounds. Além disso, é preciso considerar que, quando os resíduos dos produtos de limpeza são dispostos no ambiente de forma inadequada, os corpos d'água e o solo são afetados, poluindo o ambiente como um todo.

Esta pesquisa aborda a gestão da Qualidade do Ar Interior (QAl) sob a óptica da minimização de risco à saúde, inserindo uma discussão sobre a escolha de produtos de limpeza adequados para a higienização de interiores, os quais são denominados produtos saneantes domissanitários 
pela Agência Nacional de Vigilância Sanitária (ANVISA) do Ministério da Saúde (MS). Dentro da categoria de produtos saneantes domissanitários de ação antimicrobiana, a subcategoria de desinfetantes de uso geral foi selecionada como objeto de pesquisa.

Além das propostas de encaminhamento das soluções de ordem política e técnica, este estudo apresenta as diretrizes básicas para formulação de desinfetantes $e$ as recomendações para 0 desenvolvimento de desinfetantes ambientalmente preferiveis principalmente quanto à QAl e à proteção da Saúde Pública.

No decorrer do texto, os produtos em estudo serão mencionados como desinfetantes de uso geral (MINISTÉRIO DA SAÚDE 1988) ou simplesmente como desinfetantes. Quanto aos termos relativos ao ar, serão referidos sempre como Ar interior, a exemplo das expressōes Qualidade do Ar Interior e Meio Ambiente Interior (MAl), embora expressões mais extensas tais como Qualidade do Ar de Interiores, Qualidade do $\mathrm{Ar}$ Ambiental Interior e Qualidade do Ar de Ambientes Interiores sejam encontradas na literatura.

A seguir é apresentado o resultado da revisão bibliográfica, que constituiu na busca de um referencial para os temas necessários à escolha dos métodos de análise mais adequados, o estabelecimento de parâmetros e critérios de avaliação dos produtos estudados e a análise da legislação pertinente ao estudo.

\subsection{Qualidade do Ar Interior e Saúde Ambiental}

$\mathrm{Na}$ década de 1960, o meio ambiente era entendido sob o ponto de vista preservacionista, compreendendo ar, solo e água. Só mais tarde passou-se a entender o meio urbano também como um ecossistema. Pela definição legal, meio ambiente é "o conjunto de condições, leis, influências e interaçōes de ordem física, química e biológica, que permite, abriga e rege a vida em todas as suas formas" conforme o Artigo 3, Inciso I da lei 6.938/81. 
Isto inclui, portanto, o ambiente interior. Em termos de Vigilância Sanitária classifica-se 0 meio ambiente em natural, construído e de trabalho (EDUARDO 1998).

Com a comprovada tendência à urbanização que se verifica em todo o mundo, a qualidade ambiental interior (ambientes construídos ou fechados) assumiu grande importância em Saúde Pública. Os habitantes das cidades passam cerca de $70 \%$ a $90 \%$ do seu tempo em ambientes fechados (CRUMP 1995). Os edifícios que proliferam nos grandes centros urbanos, são ambientes potencialmente insalubres, especialmente para os trabalhadores, que passam muitas horas diariamente nesses ambientes.

A arquitetura moderna tem criado ambientes cada vez mais fechados e impermeáveis às trocas de ar com o ambiente externo. Com isto acumulamse nos ambientes interiores poeira (principalmente os residuos resultantes da descamação da pele humana), fumaça de cigarro e de preparação de alimentos, subprodutos tóxicos de atividades tais como cópia de documentos, obras de reformas, COVs provenientes de produtos de limpeza, resinas sintéticas de pisos e acabamentos, bem como da sudorese e respiração humana. Além do efeito intrínseco destes poluentes sobre a saúde humana, eles favorecem a proliferação de microorganismos configurando-se assim a interação entre os poluentes químicos, físicos e biológicos (MAGNANI et. al. 1999).

Uma vez que a respiração é a principal necessidade vital do ser humano, a área de QAl está voltada para a preocupação de como o ar interior afeta a saúde e o bem estar daqueles que estão expostos a ele $e$, tecnicamente, como o ar interior satisfaz aos três requisitos básicos para a ocupação humana: aceitabilidade térmica, manutenção das concentrações normais de gases no ar, diluição e remoção dos contaminantes a níveis não prejudiciais à saúde ou a limites de desconforto olfativo (BROOKS e DAVIS 1992).

A área de QAl é muito recente; conta atualmente com menos de três décadas no mundo e tornou-se assunto de Saúde Pública no Brasil em 1990, quando a Organização Mundial da Saúde (OMS) chamou a atenção 
do mundo para os problemas de exposição crônica a agentes contaminantes do ar. Além disso, nesta década, houve um grande aumento do número de prédios com sistema de ar condicionado central, elevando os riscos de doenças decorrentes da má qualidade do ar interior (GIODA e AQUINO NETO 2000a). Limpar e higienizar passou a ser uma questão de Saúde e não apenas de aparência. Desde então, a problemática da qualidade ambiental de interiores tem sido colocada não só em diversos artigos científicos, mas também na mídia (ANONYMUS 2000; ANONYMUS 2001) evidenciando que esse tema é de interesse do cidadão comum, uma vez que todos são usuários de ambientes interiores e podem ter sua saúde comprometida pelos contaminantes presentes, principalmente no ar.

De acordo com MAGNANI et. al. (1999), os principais sistemas biológicos que podem ser afetados pela poluição do ar interiores são a pele, as mucosas e o sistema respiratório. Assim, grande parte dos sintomas das intoxicações são alergias, dermatites, dificuldades respiratórias, coriza e lacrimejamento, os quais levam a problemas mais graves e outras conseqüências devido ao efeito cumulativo da exposição repetitiva a múltiplos agentes, implicando no aparecimento de tumores, inclusive câncer. Quando os grandes sistemas controladores do funcionamento biológico - sistemas nervoso e endócrino - são afetados, ocorrem também efeitos psicológicos, comprometendo o humor, a capacidade de concentração, etc. Os poluentes físicos e químicos são os principais agentes causadores desses problemas.

Já no século XVI, Paracelsus afirmava que todas as substâncias são tóxicas; a diferença entre um veneno e um remédio é a dose. É preciso levar em conta, que o efeito de uma dada substância no organismo é o resultado da combinação entre toxicidade e exposição, ou seja, concentração, duração, frequência, forma e via de entrada do toxicante no organismo. Assim, a natureza do toxicante define o perigo, que de acordo com as condições de exposição, determina o grau de risco (WHO 2002). 
Prever e prevenir efeitos indesejáveis nos organismos vivos, resultantes da superexposição a agentes químicos e físicos, é o papel da toxicologia na sociedade moderna. A Toxicologia é uma ciência multidisciplinar que avalia quantitativamente a totalidade das alterações biológicas produzidas pela exposição a substâncias químicas, e procura o estabelecimento das relações dose-efeito e dose-resposta para uma avaliação de risco completa. O entendimento das rotas de absorção, a distribuição e a excreção das substâncias químicas, torna-se essencial uma vez que uma dada substância é considerada perigosa se ela tem capacidade de atingir algum órgão sensivel em quantidade suficiente. Em termos de grau de risco, para toda substância, deve existir alguma condição de exposição que seja segura, à exceção dos carcinógenos e mutagênicos (ZANINI e OGA 1994).

A toxicocinética é o termo que abrange estudos toxicológicos de absorção, distribuição, biotransformação (metabolismo) e excreção de substâncias químicas. No dia-a-dia das pessoas e em atividades ocupacionais, as rotas de absorção mais freqüentes são o aparelho digestivo (via digestiva), a pele (via dérmica) ou os pulmōes (via inalatória). Geralmente, as moléculas pequenas são mais facilmente absorvidas do que as grandes, e gases são facilmente absorvidos através dos pulmões. É importante enfatizar que quando substâncias químicas alcançam os pulmōes, elas podem atingir o cérebro sem passar pelos mecanismos de desintoxicação (DANISH TOXICOLOGY CENTRE 1992).

Vários são os fatores que determinarão se uma pessoa em particular terá sua saúde afetada por um poluente ou não, incluindo-se principalmente, a dose e a duração da exposição, a freqüência de exposição bem como a forma como a pessoa entrou em contato com o poluente. Além disso, outras substâncias à qual ela está exposta, sua idade, sexo, dieta alimentar, estilo de vida e o estado geral de saúde também devem ser considerados.

Alguns poluentes químicos, como os provenientes de produtos domissanitários inadequados, são liberados ou gerados diariamente nos ambientes, podendo afetar a saúde dos ocupantes, em especial dos 
alérgicos e das pessoas que aplicam os produtos. Este é um dos problemas estudados na área de QAI. Contudo, é difícil desenvolver estudos para correlacionar de forma segura, os problemas de saúde com o ambiente, pois estes problemas são multi-fatoriais (MIKATAVAGE et. al. 1995).

A sociedade civil, o Estado e o empresariado começam a se conscientizar de que é necessário investir na qualidade ambiental interior valorizando a busca por edifícios saudáveis.

\subsection{Síndrome do Edifício Doente}

A expressão Síndrome do Edifício Doente (SED) foi cunhada pela OMS em 1983 (WHO1983) e refere-se à relação de causa e efeito entre as condições ambientais de trabalho e a redução da produtividade do trabalhador, decorrente de agressões ao bem-estar e conforto, observadas nesses locais.

Um edifício é classificado como doente quando o número de trabalhadores com reclamações de mal-estar ultrapassa $20 \%$. Apesar de ser uma expressão pouco conhecida no Brasil até o ano de 1998, nos paises desenvolvidos, tem sido objeto de estudos multidisciplinares apresentados em diversos congressos e seminários e publicados em artigos (MIKATAVAGE 1995).

Entre os indicadores da SED geralmente incluem-se (BROOKS 1992; EPA 2002):

- os ocupantes do edifício reclamam de sintomas associados a desconforto agudo, dor de cabeça, irritação nos olhos, nariz ou garganta; tosse seca; pele seca ou áspera; náusea; dificuldade de concentração, fadiga e sensibilidade a odores;

- a causa dos sintomas não é conhecida e

- a maioria das pessoas que reclama, relata obter alívio logo após afastarse do edifício por algum tempo. 
Através dos dutos do sistema de ar condicionado, pode ocorrer a proliferação de agentes etiológicos, especialmente a bactéria oportunista Legionella pneumophila, que tem a capacidade de provocar um tipo de pneumonia conhecida como legionelose ou "doença do legionário" em indivíduos portadores de deficiência imunitária ou "febre de Pontiac", semelhante à gripe e em indivíduos sadios (SIQUEIRA 1992). A denominação "doença do legionário" se deve ao surto de pneumonia que afetou pessoas da região circunvizinha de um hotel da Filadélfia na década de 1970. A doença afetou primeiramente os participantes da convenção anual da Legião Americana em 1976 e foi provocada por uma bactéria até então desconhecida, que encontrou no sistema de ventilação do hotel, condições propícias para o seu desenvolvimento e ainda, um grupo de indivíduos com imunodeficiência senil, chegando a provocar mortes. Legionella pneumophila foi a principal legionela identificada e o caso se tornou o mais conhecido entre os casos de SED (STERLING et. al. 1991). De acordo com THACKER et. al. (1978) citado por RUSSEL et. al. (1999), após esta primeira identificação, estudos sorológicos retrospectivos mostraram que esta bactéria pode ter sido responsável por surtos de doenças antes de 1965. Ficou demonstrado que o novo gênero continha espécies isoladas anteriores a 1947 (MCDADE et. al. 1979 citado por RUSSEL et. al. 1999).

A proliferação dos chamados edifícios inteligentes levou à necessidade do uso de sistemas de ar condicionado para fins de conforto térmico e para que estes sistemas se tornassem mais econômicos, principalmente após a crise de energia surgida em 1973 nos Estados Unidos, a taxa de renovação do ar era reduzida, provocando o acúmulo de poluentes no ar. É por esta razão que a questão da SED está intimamente ligada aos sistemas de ar condicionado (MILLER e KELLER 1991).

A tendência da arquitetura brasileira tem sido, na maioria das vezes, inspirada na arquitetura de outros países de clima diferente, os quais verticalizaram as suas construções, criando edifícios fechados e cada vez mais impermeáveis às trocas com o ambiente externo. 
Os sistemas de ar condicionado de grande porte compõem-se basicamente da sala de máquinas (setor primário), dos dutos e difusores (setor secundário) e do ambiente ocupado pelas pessoas onde é injetado $\circ$ ar (setor terciário).

A principal causa de poluição biológica nos ambientes climatizados artificialmente é a bandeja de condensados das máquinas pelo fato de acumularem água, principal meio de desenvolvimento de microorganismos, e de haver formação de biofilmes. A microbiota formada é aspergida nos ambientes devido à pressão negativa (SIQUEIRA et. al. 1995).

No Brasil, um dos primeiros trabalhos em ar condicionado realizado num prédio de São Paulo com esta preocupação, a pedido da empresa mantenedora do sistema de ar condicionado, apontou para a necessidade de controle microbiológico das bandejas de águas de condensação do sistema de ar condicionado. Encontraram-se várias bactérias, entre elas, 3 espécies de Pseudomonas e algumas anaeróbias (SIQUEIRA 1992).

Além das bactérias, outros agentes etiológicos que podem estar presentes no ar são os vírus, que provocam infecções nas vias respiratórias, e os fungos, que provocam hipersensibilidade, alergia e irritações nas mucosas oculares, nasais e orofaringeas.

Além do descuido na manutenção e limpeza das máquinas e dutos do sistema de ar condicionado, o principal fator que compromete a QAl é a baixa taxa de renovação do ar do edificio, definida em $\mathrm{m}^{3} / \mathrm{h} /$ pessoa. Raramente o ar passa por renovação total, porque isto implicaria em alto consumo de energia. $O$ tipo de filtro utilizado na captação de ar nem sempre está de acordo com as normas específicas. Dessa maneira, o aparelho de ar condicionado, quando mal instalado, mal regulado e com manutenção incorreta ou inexistente, pode transformar-se num verdadeiro acumulador ou concentrador de poluentes, que vão afetar a saúde dos ocupantes do setor terciário do sistema. Além disso, é importante que sejam observadas as regras para a realização de obras e atividades de limpeza, que geram poluentes, no setor terciário (DANTAS 1999). 
O simples fato do aparelho de ar condicionado estar desregulado em termos de taxa de renovação de ar, temperatura, etc., pode levar à redução da umidade do ar, e isto provoca secura nas vias respiratórias superiores, problemas pulmonares e outros. Os aparelhos de ar condicionado, indispensáveis nos edifícios fechados, podem tornar-se verdadeiros aspersórios de agentes etiológicos e alergênicos, pois os dutos dos equipamentos de ventilação raramente são limpos, conforme afirma DANTAS (2000), acumulando assim, sujeira e umidade, condição propícia ao desenvolvimento de microorganismos.

A fumaça de cigarro é um poluente bastante conhecido e desde 1991 foi declarada como um carcinógeno pela USEPA (BLUEMEN e BURNS 1995). O artigo "Ar condicionado é pior que fumo", publicado na revista CIPA (1992) situa outro aspecto relacionado à síndrome dos edifícios doentes: conforme recomenda o Ministério do Trabalho, em todos os locais de trabalho, deve-se adotar medidas restritivas ao hábito de fumar (Portaria MT № 3.257, de 22 de setembro de 1988), medidas estas que já estão incorporadas em grande parte dos prédios de escritórios. Entretanto, a concentração de microorganismos nos dutos de ar condicionado é tanto ou mais perigosa para a saúde do que a fumaça dos cigarros. A solução para este problema justificaria a realização de campanhas de conscientização semelhantes às campanhas antitabagismo, muito comuns hoje em dia.

Eliminar os aparelhos de ar condicionado não seria uma solução para os problemas que a sua má instalação e manutenção trazem, pois em lugar da questão da má qualidade do ar, teríamos um ambiente abafado e sem conforto térmico, que também constituem fatores de agravo de doenças. Desenvolver tecnologia adequada para evitar que as doenças dos edifícios modernos se instalem, é o grande desafio multiprofissional que se apresenta. 


\subsection{Poluição do ar interior e seu impacto sobre a Saúde}

Apesar da correlação existente entre saúde e meio ambiente, os grandes problemas ambientais começaram a ser discutidos somente há cerca de três décadas. Muito mais tardio é o reconhecimento da importância da Qualidade do Ar Interior em ambientes públicos, residenciais, comerciais e industriais para a saúde e sua manutenção. As pessoas carregam para dentro de suas casas, grande diversidade de materiais e facilidades que a tecnologia tem proporcionado, e os seleciona geralmente por critério de preço e estética, sem observar a quantidade e variedade de contaminantes biológicos, químicos e fisicos associados. Assim, a maioria dos poluentes é originada dentro dos interiores pelos próprios ocupantes, sem que eles tenham plena noção dos riscos envolvidos.

Segundo CRUMP (1995), entre as fontes de poluentes químicos de maior impacto sobre a saúde, destacam-se os materiais de acabamento ou revestimento e os produtos químicos de consumo em geral, ou seja, aqueles produtos que os cidadãos podem adquirir no varejo. Alergias e doenças provocadas pelas más condições do ambiente de trabalho resultam em mal-estar e desconforto que, por sua vez, levam à queda de produtividade e absenteísmo no trabalho (SANTOS et. al. 1992; BURGE e RICHARDSON 1994). Entretanto, FISK (1997) coloca, com base em estudos sobre produtividade e saúde de ocupantes de ambientes interiores, que os custos necessários para melhorar as condições ambientais interiores, com açōes corretivas como o aumento das taxas de renovação do ar e o aumento do grau de filtragem, foram estimados entre 18 e 47 vezes inferiores às economias potenciais com ganhos de produtividade e diminuição de sintomas relacionados à SED.

A ocorrência de alergias é crescente na população mundial e há a projeção de que $50 \%$ da população dos países industrializados sofrerão de doenças alérgicas até a metade do século XXI. Os microclimas de locais isolados termicamente são apontados como uma das causas desta projeção (SANCHEZ 2001). Isto representa também uma preocupação para as 
empresas brasileiras, centrada na qualidade do ar respirado nos escritórios, mais especificamente à disseminação de agentes patogênicos e/ou alergênicos, por intermédio de aparelhos de ar condicionado. Da mesma forma, é crescente o número de consumidores que sofre de alergia, por isso os produtos de limpeza antialérgicos ganharão cada vez mais demanda (KRISTOFF 2000).

Outra questão de grande importância epidemiológica é a questão da qualidade de ambientes hospitalares. Situações críticas em unidades de terapia intensiva e centros cirúrgicos já foram encontradas. Um verdadeiro ecossistema constituído por mais de dez espécies entre amebas, fungos e algas, na concentração de 1.000 a 30.000 .000 UFC/mL foi encontrado em hospitais da rede privada em São Paulo. As análises foram realizadas nas bandejas de 13 sistemas de ar condicionado de três hospitais de grande porte particulares da cidade de São Paulo. Os sistemas de ar condicionado encontravam-se em áreas críticas e semicríticas, tais como salas cirúrgicas (SIQUEIRA et. al. 1992, 1995).

Certas práticas e certos conceitos antigos, transmitidos nos cursos destinados ao pessoal médico, mais exatamente da administração hospitalar, necessitam ser revisados a fim de melhor controlar as causas de infecção hospitalar. Sendo o hospital um ambiente de uso público e coletivo, a avaliação e gerenciamento da Qualidade do Ar Interior se configura num tema de especial relevância. WHITE (1981) alerta para a grande mudança do cenário dos hospitais, que requer novas técnicas e soluções de engenharia sofisticadas para atender às preocupações de limpeza da atmosfera, especialmente dos laboratórios e centros cirúrgicos hospitalares.

O pessoal médico e paramédico é particularmente exposto a determinadas doenças, como tuberculose e hepatite, em relação à maioria da população e também doenças de pele e câncer, que podem resultar de situações de exposição a contaminantes químicos provenientes das operações de desinfecção de superfícies e instrumentos cirúrgicos, por exemplo. Além do problema ocupacional, a exposição de pacientes a esses fatores ambientais 
pode trazer sérios agravos de doenças. Trata-se de mais uma prioridade para as Comissões de Controle da Infecção Hospitalar ( $\mathrm{CClHs}$ ).

Segundo o manual Industrial Ventilation (ACGIH 1995), existem as seguintes fontes de poluição do ar: vazamentos de água (janelas, tetos, fontes de água, etc), máquinas de fotocopiar, impressoras a laser, plantas, produtos químicos para controle de pragas, produtos de limpeza e outros. Existem ainda diversos tipos de acabamentos, entre eles as tintas petroquimicas e os vernizes, que podem introduzir contaminantes químicos no ambiente, como as resinas de formaldeído, muito utilizadas em móveis de madeira aglomerada, para preservação de madeira em geral, divisórias e cola para fórmica, carpetes e pisos de vinil, inclusive acabamentos do interior de automóveis (MORENO 1978; STERLING et. al. 1991; MAGNANI et. al. 1999).

Além dos danos à saúde da população, a poluição do ar interior pode provocar impactos na Economia pelos danos a materiais e equipamentos, bem como aumentar o custo dos sistemas de saúde devido aos custos médicos gerados (BROOKS 1992).

Poucos pesquisadores em âmbito nacional e internacional têm estudado a questão da poluição química do ar de interiores. Ainda mais raros são os estudos voltados para o uso de produtos para higienização de interiores. WOLKOFF (1998) em seu artigo "Risk in cleaning: chemical and physical exposure", alerta para a necessidade de se desenvolver novos conceitos tecnológicos em relação aos agentes e processos de limpeza e para a falta de estudos sistemáticos nesta área. Estudos de monitoração da qualidade do ar e medidas de emissão no ar são mais numerosos na literatura, porém estão, em sua grande maioria, voltados para os contaminantes biológicos e físicos.

$\mathrm{Na}$ realidade, há poucos profissionais em Química desenvolvendo estudos de pesquisa na área de QAI. Considerando a atual carência no mundo, de estudos sobre contaminantes químicos do ar interior, os quais têm importante interação com os agentes microbiológicos e físicos, o que pode 
levar ao agravamento da SED, torna-se importante e necessária a reavaliação do uso dos produtos de higienização de maior risco para a saúde humana. Além disso, tanto ou mais importante do que despender esforços e recursos para se efetuar inúmeros estudos, com o objetivo de amostrar e analisar as emissões nos interiores visando constatar a necessidade de se monitorar e controlar a sua qualidade, seria 0 investimento em programas e políticas de prevenção da poluição (YOCOM 1994) e a definição de fatores de emissão para os COVs mais comuns. Neste aspecto, é importante salientar, que o requisito básico para se caracterizar uma fonte de emissão de contaminantes é conhecer a sua composição química. Quanto aos produtos saneantes domissanitários utilizados na higienização de interiores, a fórmula desenvolvida pelo fabricante é registrada no Ministério da Saúde - ANVISA, o que aponta para a necessidade de se examinar a regulamentação e fiscalização pelo Estado.

\subsection{Compostos Orgânicos Voláteis e a Poluição Química do Ar Interior}

Conforme a definição da ATSDR (Agency for Toxic Substances and Diseases Registry) dos Estados Unidos, compostos orgânicos voláteis são substâncias químicas contendo carbono e diferentes proporções de outros elementos tais como hidrogênio, oxigênio, cloro, flúor, bromo, enxofre ou nitrogênio. Estas substâncias tornam-se facilmente vapores ou gases. Um número significativo de COVs provenientes do processo de higienização de interiores pode poluir 0 ar interior, podendo causar desde problemas respiratórios leves até câncer (ATSDR 2002).

Cabe lembrar que as neoplasias, doenças e agravos à saúde caracterizadas por tumores, muito relacionados à vida moderna, são a terceira causa de morte no Brasil, depois das cardiovasculares e de causas externas (MINISTÉRIO DA SAÚDE 2001).

O uso destes compostos no dia-a-dia das pessoas é muito amplo, incluindo combustiveis, produtos de limpeza e desinfecção, tintas, cosméticos, 
fixadores de cabelo, adesivos, solventes, fragrâncias, aromatizantes, máquinas copiadoras e vários outros. Podem ainda estar incorporados em materiais de construção e revestimentos. Os COVs existem como líquido ou vapor na temperatura ambiente mas podem ainda ser encontrados na forma sólida como por exemplo o naftaleno, o p-diclorobenzeno, que são utilizados como desodorizantes para banheiro. Uma compilação de 307 COVs identificados no ar interior de diferentes países foi publicada em 1986 (WHO 1987).

As concentrações de COVs geralmente são maiores dentro dos edifícios e residências do que no ar externo. Através de um estudo realizado pela Agência de Proteção Ambiental dos Estados Unidos (USEPA) em várias partes do país, descobriu-se que o nivel de poluição interior de algumas residências chegava a ser dez vezes superior ao encontrado na via pública, mesmo em locais próximos às refinarias de petróleo (MAGNANI et. al. 1999).

Os COVs podem ser classificados de acordo com a pressão de vapor ou ponto de ebulição. Orgânicos voláteis são aqueles compostos cuja pressão de vapor a $25^{\circ} \mathrm{C}$ é maior do que $10^{-1} \mathrm{mmHg}$ e cujo ponto de ebulição está entre 50 e $260^{\circ} \mathrm{C}$. Semi-voláteis (COS- $V$ ) são aqueles que apresentam pressão de vapor a $25^{\circ} \mathrm{C}$ entre $10^{-1}$ e $10^{-7} \mathrm{mmHg}$ e cujo ponto de ebulição está entre $260^{\circ} \mathrm{C}$ ou $400^{\circ} \mathrm{C}$ (YOCOM e MCCARTHY 1994; CRUMP 1995). Entre os exemplos destes compostos estão alguns álcoois $\mathrm{e}$ hidrocarbonetos aromáticos, respectivamente.

Há ainda o grupo dos Compostos Orgânicos Altamente Voláteis (COAV) cuja pressão de vapor é maior do que $80 \mathrm{mmHg}$ a $20^{\circ} \mathrm{C}$ (EPA, 1998) como é o caso do formaldeído cuja pressão de vapor é $96 \mathrm{mmHg}$ a $20^{\circ} \mathrm{C}$ conforme a ficha de segurança do produto da PROMEGA (2002). Consideraremos neste estudo, os COVs de maior toxicidade e volatilidade e que são mais comuns na composição química de desinfetantes de uso geral no Brasil, que se constituem em fontes importantes de poluição interna em ambientes residenciais e coletivos. 


\subsection{Uso de produtos saneantes domissanitários para higienização de interiores}

Para se ter uma noção de tamanho de mercado, o faturamento líquido do setor de produtos de limpeza em 2001 foi de US\$ 2 bilhões (ABIQUIM 2002). As categorias de produto de limpeza doméstica estão distribuídas quanto à participação de mercado, de acordo com a tabela a seguir.

Tabela 1- Participação de mercado das categorias de produtos de limpeza doméstica .

Categoria

Participação de mercado (\%)

Detergentes/sabões

Desinfetantes

Amaciantes de roupas

Detergentes lava-louças

Ceras para pisos

6

Hipoclorito de sódio

6

Lustra-móveis

2

Outros

27

TOTAL 100

Fonte: ABIPLA (1999); Euromonitor Internacional (2000).

Os diversos tipos de fórmula de saneantes domissanitários podem ser entendidos de acordo com a segmentação do mercado e são denominados doméstico, institucional e industrial (I\&I). Os saneantes institucionais são aqueles utilizados por profissionais da limpeza em hoteis, hospitais, restaurantes, etc. Os de uso industrial, como o próprio nome indica, são 
aqueles utilizados nas indústrias, como por exemplo, de alimentos, cosméticos, de papel e celulose, para a higienização de seus equipamentos, instalações etc. Cabe fazer aqui uma observação sobre o mercado de produtos $|\&|$. Há os produtos comodato, que apresentam fórmula tradicional e são fornecidos por vários fabricantes e há aqueles que são comercializados de forma associada a serviço, por fornecedores que possuem uma ampla linha de produtos químicos e ainda oferecem sistemas de dosagem automática e assistência técnica para implantação das melhores práticas de higienização, incluindo treinamento para capacitação de mão-de-obra e outros diferenciais.

Utilizando-se as denominações de categorização dos produtos adotada pela ANVISA, os produtos de ação antimicrobiana se dividem em subcategorias segundo a sua finalidade, correlacionada com as especificações dos microorganismos para avaliação da ação antimicrobiana. Os desinfetantes de uso geral constituem uma dessas subcategorias.

Para estudar os problemas envolvidos no uso de produtos saneantes para higienização de interiores, faz-se necessário conhecer como se processa a escolha do produto. Nesse sentido, alguns aspectos da realidade do mercado de produtos saneantes são descritos a seguir.

Os processos de limpeza e higienização têm interferência direta na Qualidade do $\operatorname{Ar}$ Interior, pois se estes processos são realizados inadequadamente e com o sistema de ar condicionado ligado, o ar acaba sendo contaminado, uma vez que nenhum filtro é $100 \%$ eficaz (ALEXANDRE 1995). Processos de limpeza e higienização de interiores ineficazes podem provocar doenças e resultar em agravamento dos riscos à saúde humana, devido ao desenvolvimento de microorganismos, especialmente as bactérias, resistentes aos princípios ativos.

Toda operação de manutenção da limpeza e higiene de ambientes interiores de uso residencial, público e coletivo envolve processos, procedimentos, pessoas e produtos, compreendendo os produtos químicos, os equipamentos e os materiais de acabamento (LOURENÇO 1998). Por 
melhor que seja a qualidade do trabalho de manutenção e limpeza, este normalmente passa despercebido e somente quando algo não está bem é que ele é notado (MCLAUGHLIN 1969). Este fato faz com que o trabalho de higienização de interiores seja, com freqüência, negligenciado e desvalorizado, não recebendo atenção e recursos apropriados. Entretanto, este deveria fazer parte dos sistemas de gestão da qualidade interior, até por uma questão de redução de custo.

A sistematização dos processos de limpeza e higienização é uma preocupação antiga que envolve escritórios, fábricas, cozinhas, hospitais, etc. Pisos, carpetes, paredes, mobiliário, sanitários, equipamentos, etc., necessitam de manutenção de limpeza (MCLAUGHLIN 1969; DANTAS 1999). A necessidade de padronização dos processos de limpeza levou a ABRALIMP a lançar em 1999 o primeiro Manual de Processos de Limpeza Profissional, que enfoca os procedimentos para limpeza e higienização das superficies fixas nos ambientes de uso coletivo, onde a falta de cuidados representa graves efeitos sobre a saúde das pessoas. No entanto, 0 capítulo referente a "Uso de Produtos Químicos" adequados às normas, e que trataria do controle de conformidade, precisa ser ainda elaborado (ABRALIMP 1999). Até o segundo semestre de 2002, esta complementação do manual ainda não havia sido iniciada. Ou seja, falta uma sistematização dos processos de limpeza e higienização no que concerne ao uso correto de produtos.

Quem faz a escolha do produto e como o faz são questões que merecem uma análise. No ambiente de uso residencial, é o ocupante ou morador quem exerce diretamente a escolha dos produtos, normalmente a chamada dona-de-casa. Estes produtos podem ser encontrados no varejo. $O$ estudo dos produtos saneantes usados em residências é muito importante sob o ponto de vista de Saúde Pública, pois crianças e idosos são os dois grupos mais susceptiveis da população e são os que vivem mais tempo confinados em ambientes residenciais. 
Nos ambientes de uso público e coletivo de pequeno a médio porte representados geralmente por algumas escolas, escritórios, consultórios, lojas etc, a escolha é exercida pelos proprietários dos estabelecimentos, compradores e/ou aplicadores que não são profissionais ou técnicos. Nestes casos também são utilizados os mesmos produtos que se utiliza em residências. Os produtos de limpeza de uso profissional são mais utilizados nos ambientes de grande porte.

Tanto no caso do ambiente residencial como do ambiente de uso público e coletivo de pequeno a médio porte, a escolha do produto normalmente se faz segundo critérios de preço e aparência (MAGNANI 1999) bem como o perfume, critérios estes baseados em comportamentos de compra e hábitos de uso arraigados e difíceis de mudar (JANITORIAL PRODUCTS 2001).

Nos ambientes de uso público e coletivo de grande porte como Shopping Centers, aeroportos, grandes torres de escritórios e indústrias, justifica-se a contratação pela administração do condomínio das chamadas limpadoras de empresas, que se responsabilizam pela higienização do ambiente. No caso de limpadoras responsáveis que contam com profissionais capacitados e treinados, a escolha dos produtos é realizada por um técnico e com base muito mais em critérios de performance e eficácia, do que de preço, perfume e aparência. A aplicação é orientada de acordo com as instruções dos fabricantes dos produtos. Estes produtos fazem parte do segmento institucional e são adquiridos no mercado atacadista, em distribuidores de produto de limpeza ou diretamente do fabricante.

Entretanto, é muito importante enfatizar que o mercado distribuidor atacadista também comercializa os produtos domésticos, ou seja, as mesmas marcas e fórmulas que o consumidor compra nos supermercados ou varejo em geral, conforme pôde ser confirmado nos contatos realizados com cinco distribuidores anunciantes e suas respectivas páginas na rede internet, localizados nas 5 diferentes zonas da Grande São PAULO (GUIA DE INFORMAÇÕES COMERCIAIS 2001). Portanto, os produtos do segmento de uso geral, comercializados em supermercados, têm grande 
importância no estudo da Qualidade do Ar Interior, pois os poluentes químicos que são gerados impactam a saúde das pessoas quando elas estão em suas casas ou nos ambientes de trabalho, públicos e coletivos, estejam elas estudando, trabalhando ou se divertindo.

O incentivo do uso correto dos produtos saneantes domissanitários é um papel que cabe primordialmente aos fabricantes de produtos e, em primeira instância, aos fabricantes de matérias-primas, os quais se situam no início da cadeia produtiva ou do ciclo de vida do produto, por desenvolverem e lançarem no mercado novas matérias-primas, cujo conhecimento deve ser transmitido aos fabricantes do produto final (PETILLO 1997).

De forma semelhante ao que acontece com o uso inadequado de antibióticos, a subdosagem de desinfetante pode levar à formação das chamadas superbactérias (LEVY 1998). Além disso, resíduos de desinfetantes podem ser encontrados na água e no solo. Estudos europeus demonstram que produtos antibacterianos podem ser encontrados em corpos d'água de abastecimento (U.S. GENERAL ACCOUNTING OFFICE 1999). Este fato evidencia o problema da interação da poluição interior com a exterior. Um ciclo vicioso se forma quando os princípios ativos desinfetantes existentes são utilizados de forma inadequada, pois ao gerar microorganismos mais resistentes, a tecnologia é desafiada no sentido de oferecer principios ativos novos e mais eficazes, que por sua vez, ao serem mal utilizados, geram microorganismos ainda mais resistentes. Isso tem levado alguns cientistas a preconizarem que o grande desafio da Saúde no próximo milênio serão as doenças infecciosas. Daí a necessidade de se gerenciar a questão do uso de biocidas de forma integrada (PESTICIDE MANAGEMENT - EPA 1990). A Agência Nacional de Vigilância Sanitária do Ministério da Saúde é um dos agentes responsáveis pela autorização e licenciamento de produtos químicos e recomendação de boas práticas para o uso de biocidas, produtos domissanitários e de uso pessoal.

A questão da possível formação de bactérias resistentes devido à subdosagem do produto e conseqüentemente do princípio ativo microbicida, 
merece estudos e reflexões (DIEHL et. al. 2000; MAILLARD e RUSSEL et. al. 2001). Passando a dosar corretamente o produto, o consumidor estaria fazendo uso do produto como desinfetante e efetivamente protegendo sua saúde e de sua família. Entretanto, sob o ponto de vista da QAI, desse modo, seria mais alta a concentração de COVs no ar, acentuando-se assim os problemas de saúde na população como alergias e problemas respiratórios em geral.

Esta é mais uma razão para se incentivar o uso de produtos desinfetantes que não contenham COVs ou cuja taxa de volatilidade seja a menor possivel. Pela mesma razão, a categoria que merece ser pesquisada com relação à emissão de COVs é a de limpadores antibacterianos, uma categoria que surgiu no Brasil por volta do ano de 2000. Trata-se de fórmulas desenvolvidas para limpar e desinfetar ao mesmo tempo. Além da detergência necessária para a remoção de gordura e outras sujidades, o produto geralmente só apresenta eficácia microbiológica quando usado puro e mantido em contato com a superfície por 10 minutos, tal como no caso dos desinfetantes. Ao ser utilizado na forma diluida, o princípio ativo está sendo subdosado.

É preciso chegar-se a um consenso com relação à etapa da limpeza ser separada da de desinfecção. Este conceito favorece a eficácia e prevenção da formação de bactérias resistentes, porém vai contra os produtos de múltipla função, como os antibacterianos, cujos propósitos são redução do ciclo de tempo dos processos de higienização e praticidade.

Com relação às causas do mau uso de produtos de limpeza, cabe registrar aqui o fato da mídia, falada e escrita, ser responsável, em grande parte, pela disseminação da cultura do "faça você mesmo", divulgando as receitas de produtos com base na mistura de diferentes materiais. Há revistas, programas de televisão, jornais e até livros que freqüentemente trazem alguma receita, instrução ou a chamada "dica" de como remover manchas, preparar uma solução de facilitador de passar roupas e assim por diante. Algumas receitas podem provocar danos à saúde, além de não cumprirem o 
seu papel. Isto transmite a noção de que não é necessário dispor de tecnologia ou ter grandes preocupações com segurança para produzir um produto de limpeza. Por sua vez, este conceito errôneo leva à noção de que se pode usar os produtos livremente, em misturas diversas sem precisar sequer consultar o rótulo.

Se todos lessem o rótulo dos desinfetantes, não seria surpreendente a tantas pessoas o fato de que para desinfetar o vaso sanitário mais o piso de um banheiro, é necessário gastar quase um frasco de $500 \mathrm{~mL}$ de um determinado produto desinfetante, pois o fabricante recomenda claramente no rótulo que o produto tem que ser usado puro como desinfetante uma vez que, diluido, cumpre apenas a função de limpar a sujeira, sem matar as bactérias. Por isso, o que acontece na maioria das vezes, é uma limpeza e não uma desinfecção, havendo então uma falsa idéia de proteção contra doenças infecciosas.

$\mathrm{Na}$ busca de produtos adequados para a higienização de interiores é preciso que a ética do Desenvolvimento Sustentável seja observada, através do uso correto de produtos certificados que garantam a qualidade de vida nos dias de hoje e das próximas gerações. Delineia-se aqui a necessidade de se investir na educação, melhorando o programa de ensino dos profissionais que atuam nesta área: arquitetos, químicos formuladores; engenheiros e médicos, como também na mudança de hábitos do consumidor, acostumado a fazer misturas ou coquetéis de produtos de limpeza e a avaliar a higiene através de aparência e perfume.

\subsection{Produtos de limpeza e suas formulações}

Antes de proceder à avaliação dos desinfetantes encontrados no varejo da RMSP, foi elaborada uma revisão dos conceitos de formulação e também de fabricação de desinfetantes com base na prática da indústria nos últimos 15 anos, que a autora acompanhou ao atuar na área de desenvolvimento e regulamentação de produtos de limpeza e afins. 
Devido às características climáticas e à realidade econômica de nosso país, a indústria de produtos de limpeza e higiene em geral, busca continuamente produtos de alto valor, ou seja, de alta qualidade e custo reduzido e que sejam adaptados aos hábitos locais. Portanto, as fórmulas de outros países são adaptadas ou outras são desenvolvidas de forma que não se pode tomar como base, unicamente os trabalhos realizados em outros países, e aplicá-los à nossa realidade para enfrentar a questão da contaminação do ar de ambientes interiores por produtos saneantes domissanitários.

Os tipos de fórmula dos produtos voltados para a higienização de ambientes públicos e coletivos ou domésticos são muito semelhantes e muitas vezes, iguais (MAILLARD e RUSSEL 2001). Os produtos de uso institucional e industrial, são vendidos normalmente na forma concentrada para serem diluídos pelo usuário, enquanto os produtos domésticos são vendidos na forma pronta para usar, já na diluição de uso. Na prática, as empresas não estão dispostas a pagar altos preços pela água que vem dentro das embalagens dos produtos (pode chegar a representar $90 \%$ em peso) como acabam fazendo os cidadãos, os quais acabam também pagando por mais plástico nas embalagens, que vão se transformar em resíduo a ser disposto no ambiente. Outra semelhança muito importante é que a regulamentação de produtos desses dois segmentos se dá através de uma mesma norma, que apresenta uma única lista de substâncias autorizadas.

Os principais componentes de fórmula dos produtos saneantes domissanitários são os princípios ativos (componentes ativos ou simplesmente ativos, na linguagem dos fabricantes, que é adotada nos rótulos). Podemos ter princípios ativos detergentes, desinfetantes, bactericidas, fungicidas, viricidas, anti-mofo e etc. Estes são os componentes que exercem a função principal no produto de acordo com a finalidade de uso e os apelos/benefícios comunicados. Estes ativos são normalmente tensoativos ou surfatantes, cujo caráter iônico tem grande importância para a formulação. Geralmente, os ativos desinfetantes são tensoativos catiônicos ou não-iônicos. Dentre os demais componentes de fórmula dos produtos de limpeza cabe destacar aqui, em função da sua 
volatilidade, os solventes (ex.: etanol, propanol, polietilenoglicol e isobutilglicol), e as fragrâncias (ex.: aldeídos e óleos terpênicos) em função da sua alta volatilidade.

Os solventes, pelo seu efeito hidrótopo (aumento da solubilidade de determinadas substâncias em água) têm função auxiliar no processo de fabricação, dissolvendo os componentes da fórmula e propiciando um produto homogêneo. Auxiliam ainda na performance de limpeza e desinfecção do produto, dissolvendo substâncias gordurosas e atacando os sítios lipidicos da parede celular das bactérias $e$, assim, permitindo a entrada de princípios ativos desinfetantes.

A fragrância, além da sua função de perfumar os ambientes, é utilizada também para mascarar maus odores de outros componentes da própria base da fórmula. Ambos, solvente e perfume, são componentes da fórmula que aumentam consideravelmente o conteúdo de COVs nos produtos. São utilizados ainda corantes, opacificantes ou perolizantes, conservantes e água. Em alguns casos, inibidores de corrosão, agentes complexantes e ainda, ácidos, bases e sais tamponantes podem ser utilizados para ajuste de $\mathrm{pH}$.

Os conservantes são incluídos na fórmula dos produtos de limpeza com a finalidade de inibir o crescimento de microorganismos no próprio produto. No entanto, quando a produção está de acordo com as Boas Práticas de Fabricação (BPF), contemplando todos os seus itens: água, matériasprimas, processos de sanitização validados, controle microbiológico, instalaçōes e equipamentos adequados, bem como a capacitação dos operadores e o comprometimento de toda a organização, conforme exigido pelo MINISTÉRIO DA SAÚDE (1997), garante-se a qualidade microbiológica do produto até o final da linha de produção, minimizando assim o papel do conservante. Por outro lado, se eventualmente o consumidor contaminar o produto durante o uso, o conservante irá protegê-lo durante todo o seu prazo de validade. Para minimizar o custo-benefício do uso dos principios ativos conservantes, devem ser efetuados o controle de qualidade 
microbiológico de matérias-primas e embalagens juntamente com práticas higiênicas de fabricação.

O formaldeido é muito utilizado como conservante. Alternativas de conservantes que se pode utilizar em desinfetantes são: isotiazolinonas, hidantoinas e associações destes dois conservantes. A escolha do conservante mais adequado para cada formulação requer a observação de alguns conceitos.

De acordo com STEINBERG (1996), o sistema conservante deve ser:

- de amplo espectro de ação contra bactérias gram-positivas e gramnegativas, bolores e leveduras;

- eficaz em baixas concentrações porque não adiciona valor ao produto e não deve irritar ou causar outros efeitos tóxicos;

- solúvel em água e insolúvel em óleo pois os microorganismos se multiplicam na fase aquosa ou na interface água-óleo;

- compatível com todos os componentes da fórmula sem perder atividade por interação com algum componente ou por alguns fatores como presença de água dura, matéria orgânica, substâncias da formulação que se comportam como inativantes, temperatura, alteração de $\mathrm{pH}$, etc.

- sem cor e sem odor para não adicionar cor ou odor ao produto final ou provocar reações com outros componentes da fórmula que provoquem estas alterações;

- estável sob as variações de temperaturas e pH que podem ocorrer durante $\circ$ processo de manufatura embora nenhum composto orgânico seja estável em temperaturas e pHs extremos;

- estável ao longo do tempo de validade, suficientemente para proteger o produto durante a sua manufatura, pelo tempo de validade do produto na prateleira e durante todo o seu uso;

- seguro quando usado conforme as instruções;

- fácil de analisar utilizando métodos convencionais; 
- fácil de inativar para ser testado microbiologicamente;

- fácil de manusear, ou seja, bombeável, não inflamável e não tóxico na forma em que é fornecido;

- ser economicamente viável, desde que funcione e seja seguro pois o custo de recolhimento de produto devido a uma contaminação e o conseqüente prejuízo à imagem do fabricante não são compensadores e

- aprovado pelas agências de regulamentação dos diferentes paises ou estados onde se quer comercializar o produto.

A definição da concentração do conservante na fórmula, com base na concentração mínima inibitória do crescimento microbiano, deve ser feita com parcimônia, pois os resultados, na prática, não são consistentes, a menos que seja determinada para todos os conservantes ao mesmo tempo, contra os mesmos microorganismos-teste e no mesmo laboratório para se obter números relativos. Além disso, os testes são efetuados em solução salina o que não reflete a fórmula do produto.

Conforme comentado anteriormente, os técnicos não costumam considerar os conceitos e critérios relacionados à QAl no desenvolvimento de tecnologia de matéria-prima e produto, pois se vêem diante da limitação de conhecimento e da dificuldade técnica para a realização de estudos químico-analíticos para caracterização de fontes de emissão dadas às baixas concentrações e diversas interferências (YOCOM e MCCARTHY 1994; FORTMANN et. al. 1995) e num nivel de aprofundamento maior, da dificuldade de previsão das taxas de emissão, em função da complexidade de composições químicas e às diversas interações entre os contaminantes químicos, físicos e biológicos (WOLKOFF et. al. 1997).

\subsubsection{Formulação e produção de desinfetantes}

A sujeira invisível a olho nu constitui o objeto da desinfecção, que complementa o processo de limpeza, para se obter a higiene. Há uma 
extensa gama de produtos com ação desinfetante disponivel no mercado (EUROMONITOR INTERNACIONAL 2000).

As composiçōes de desinfetantes podem ser entendidas como soluçōes aquosas micelares. Há dois tipos gerais de componentes: os compostos orgânicos voláteis e os compostos orgânicos não-voláteis. $O$ segundo tipo pode ser exemplificado especialmente pelos tensoativos ou surfatantes como também por alguns corantes. Podem causar danos à saúde, porém como não volatilizam, serão inalados apenas na medida em que aerossóis sejam formados durante o uso do produto.

Sob o ponto de vista da qualidade do produto, a escolha do desinfetante mais correto para uso em ambientes residenciais, públicos ou coletivos depende dos seguintes fatores: eficácia, segurança e custo em uso (considerado o rendimento do produto), embora na prática, fatores subjetivos como perfume e comunicação de marca exerçam influência na escolha do produto, invariavelmente. Esta influência será tanto maior quanto menor for o nivel técnico ou profissional do consumidor ou responsável pela decisão, ou seja, a escolha do cidadão consumidor é menos criteriosa, tecnicamente falando, do que a de um administrador de hospital, por exemplo, que tem formação e informação técnica sobre os produtos. Preço é um critério de escolha de produto, sempre muito importante (BERNADO NETO 2002).

Pode-se formular desinfetantes empregando mais do que um princípio ativo, compondo-se assim um sistema ativo ou sistema bactericida, termo utilizado em formulação no caso de um desinfetante de uso geral.

O desenvolvimento dos primeiros princípios ativos desinfetantes se deu há mais de cem anos com o surgimento da Epidemiologia e, desde então, os progressos no desenvolvimento de produtos e procedimentos de desinfecção mais eficientes, seguros e econômicos têm contribuído para a proteção da saúde humana no combate às doenças infecciosas (PETILLO 1999; RUSSEL et. al. 1999). 
A escolha do princípio ativo de ação antimicrobiana depende de dois fatores: primeiramente o tipo de microorganismo a ser controlado e a composição do meio em que o ativo é utilizado. A composição e o pH da superfície podem dar uma indicação do tipo de microorganismo que a está infestando. Por exemplo, produtos contendo açúcares são atacados pelas leveduras em particular; bolores preferem meios neutros ou fracamente ácidos; bactérias decompõem principalmente produtos contendo proteínas em meio neutro ou fracamente alcalino. Quando possível, a acidificação do meio até $\mathrm{pH} \mathrm{4,} \mathrm{limita} \mathrm{o} \mathrm{crescimento} \mathrm{da} \mathrm{população} \mathrm{de} \mathrm{bactérias} \mathrm{e} \mathrm{facilita} \mathrm{a}$ conservação do produto.

A definição da concentração do princípio ativo ou sistema de ativos desinfetantes requer a realização de testes microbiológicos, chamados testes de diluição em uso. As bactérias empregadas no teste de desinfetantes de uso geral doméstico são: Salmonella choleraesuis e Staphilococcus aureus. Por isso, os desinfetantes de uso geral doméstico podem ser denominados também como bactericidas.

Embora pareça paradoxal, pode ocorrer contaminação microbiológica de desinfetantes. A principal causa é a falta de boas práticas de fabricação, especialmente com relação ao controle da qualidade microbiológica da água e à sanitização dos tanques misturadores e equipamentos da linha de produção e embalagem. É comum encontrar linhas de produção sem controle microbiológico, tanques de estocagem de água sem agitação, matérias-primas de baixa qualidade, sanitização aplicada com baixa ou nenhuma freqüência, o que acaba por promover a formação de biofilmes, ou seja, filmes de microorganismos aderidos às superfícies de tanques, equipamentos e tubulações, comprometendo inclusive a qualidade do produto, ou seja, a eficácia desinfetante.

Outra causa é o uso incorreto dos conservantes por determinados fabricantes que, a cada aparecimento de contaminação microbiológica na linha de produção, fazem pequenos incrementos na concentração do conservante na fórmula sem atacar as verdadeiras causas, provocando 
assim a seleção de bactérias resistentes ao princípio ativo (RUSSEL et. al. 1999; MAILLARD e RUSSEL 2001).

Apesar de ser uma prática comum entre os fabricantes no Brasil, partindose do princípio de que um conservante não deve nunca compensar más práticas de fabricação e se a qualidade da matéria-prima desinfetante é assegurada, isto não é necessário. Este assunto volta à pauta de discussão quando casos de desinfetantes contaminados microbiologicamente são detectados no mercado. É verdade que a função do conservante, nos mais diversos tipos de formulação, é inibir o crescimento de microorganismos no próprio produto, protegendo-o de contaminações microbiológicas provenientes da sua produção ou até mesmo do seu uso pelo consumidor, conforme se pode comprovar através dos testes de desafio (CTFA 1993; RUSSEL et. al. 1999; NEAL 2001).

Um produto desinfetante no entanto, já possui um ativo microbicida presente na formulação, cuja função é matar formas vegetativas de microorganismos nas superfícies a serem desinfetadas. Sendo este de amplo espectro e estando em concentração adequada e comprovada através de testes, a qualidade do produto estará assegurada, dispensando 0 uso do conservante, quando as BPFs são aplicadas nas linhas de produção. $O$ princípio ativo estará, então, livre para atuar contra os microorganismos-alvo e não contra aqueles provenientes das más práticas de fabricação.

A atividade antimicrobiana dos biocidas pode ser continuadamente melhorada, porém é crucial partir sempre do conhecimento da fisiologia e susceptibilidade dos microorganismos e dos mecanismos de ação das moléculas para desenvolver combinações sinérgicas e seguras. Além disso, a otimização das fórmulas de desinfetantes requer o conhecimento dos tipos de princípios ativos quanto à distribuição do tamanho de cadeia carbônica, fator que exerce influência na solubilidade, irritabilidade e eficácia do produto final.

Se a contaminação durante a fabricação é elevada, a concentração de ativo presente na formulação será baixa, tornando-se subletal. Além do produto 
perder a sua eficácia, o mais grave é que isto irá contribuir para a seleção de cepas resistentes, o que em suma representa uma ameaça à Saúde Pública. Nestes casos, faz-se necessário arcar com o custo da adição de um conservante no desinfetante (PETILLO 2002).

Antes da etapa de fabricação, é necessário confirmar os resultados do certificado de análise do princípio ativo quando do controle de qualidade no recebimento das matérias-primas. Mesmo quando o fornecedor é certificado e as suas instalações foram inclusive visitadas, este controle deve ainda ser realizado em frequências menores e aleatórias.

No anexo 1 é apresentado o Roteiro de Formulação de Desinfetantes, elaborado como resultado da presente pesquisa com o intuito de contribuir com mais detalhes sobre a formulação de desinfetantes, visando o entendimento dos resultados desse estudo, tendo em vista que a maior parte do conhecimento nesta área é gerado pela Indústria e, geralmente, a ela permanece restrito sendo dificil encontrar boas referências bibliográficas a respeito.

Os princípios ativos de ação antimicrobiana empregados na formulação de desinfetantes são substâncias químicas que apresentam um determinado grau de toxicidade, que é inerente à função do produto. Se além de tóxica, a substância for volátil, pode configurar-se uma situação de poluição química do ar interior dependendo das condiçōes de temperatura, umidade e renovação do ar no ambiente.

Sob o ponto de vista da QAl, desinfetante seguro é aquele que não contém COVs ou cuja toxicidade e taxa de volatilizaçāo sejam as mais baixas possiveis.

Dentre os COVs biocidas, o formaldeído é largamente empregado no Brasil como conservante devido ao baixo custo e alta eficácia bacteriostática, embora seja reconhecidamente muito irritante, chegando inclusive a prejudicar a performance do perfume do produto, em alguns casos. $O$ uso de derivados de fenol como princípio ativo em desinfetantes, no Brasil, é tão antigo quanto o do cloro. Nas composiçōes mais típicas, o derivado de fenol 
está associado ao óleo de pinho e ao sabão. Além de ser um agente de limpeza, a função do sabão neste tipo de fórmula é gerar o efeito emulsionante quando adicionado à água, efeito este que é muito explorado como apelo de Marketing a fim de sinalizar para o usuário uma suposta ação desinfetante do produto. Este efeito é conhecido pelos fabricantes como efeito milk ou blooming.

O formaldeído é uma das substâncias de ação antimicrobiana mais antigas que se conhece. Sua ação conservante é bastante conhecida. Seu uso como desinfetante foi primeiramente reportado em 1892 (RUSSEL et. al. 1999). Estando entre os COVs com ação antimicrobiana mais largamente empregados como conservante no mercado brasileiro, não só em produtos de limpeza como outras categorias de produtos químicos de consumo tais como higiene pessoal e cosméticos, o formaldeido é também um composto orgânico volátil extremamente irritante e classificado no grupo $2 \mathrm{~A}$ como suspeito de ser cancerígeno para o homem pela International Agency for Research on Cancer (IARC) sediada na França (CRUMB 1995).

\subsection{Propriedades físico-químicas dos compostos orgânicos voláteis de ação antimicrobiana}

Para fins de escolha dos métodos de análise e interpretação de resultados, foram pesquisadas as principais propriedades físico-químicas dos compostos orgânicos voláteis mais tóxicos comuns aos desinfetantes, que são os que apresentam ação antimicrobiana.

\subsubsection{Formaldeído}

Formaldeído é um gás incolor, inflamável, com odor forte e penetrante; pode formar misturas explosivas com o ar e oxigênio; é muito conhecido como formol mas apresenta outros sinônimos como: aldeído fórmico, metanal, oximetileno, oxometano e outros. É altamente solúvel em água (48\%) e solventes orgânicos como álcool e éter (52\%). Sua solução aquosa é um líquido incolor de odor sufocante que, quando evapora, libera formaldeído, 
que se oxida lentamente ao ar transformando-se em ácido fórmico. É um agente redutor poderoso, especialmente na presença de álcali. Normalmente é utilizado em solução aquosa, conhecida como formalina, a 37 ou $40 \%$ contendo $10-15 \%$ de metanol para prevenir polimerização. 0 formaldeído é utilizado predominantemente na síntese de compostos pela indústria química, como reagente analítico, em aditivos plásticos, concreto, produtos fotográficos, e, em menor escala, na agricultura. Em ambientes externos pode ser gerado de diversas fontes, tais como incineradores, queima de combustíveis de automóvel e exaustão de máquinas (NIOSH 1981; EPA 1988; WHO 1989; EPA 2002).

Os principais dados físico-químicos do formaldeído são os seguintes:

- Fórmula estrutural:

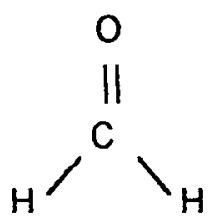

- Fórmula empírica:

$\mathrm{CH}_{2} \mathrm{O}$ ou $\mathrm{CHOH}$

- Peso Molecular, PM:

30,03

- Pressão de saturação de vapor, $P_{\mathrm{v}}: 96 \mathrm{mmHg}$ ou $128 \mathrm{hPa}$ a $20^{\circ} \mathrm{C}$

- Ponto de fusão, PF:

$-57,3^{\circ} \mathrm{C}$

- Ponto de ebulição, PE (760 mmHg): $96{ }^{\circ} \mathrm{C}$

- Densidade

$0,898 \mathrm{~g} / \mathrm{cm}^{3}$

\subsubsection{Derivados de fenol}

Os derivados de fenol têm aparência de cristais de cor branca ou amarelada e odor pungente. O mais utilizado é o clorofeno ou 5-cioro-2hidroxidifenilmetano e o-benzil-p-clorofenol (2-benzil-4-clorofenol) que resulta da substituição de dois átomos de hidrogênio do anel aromático do fenol por um grupo benzil e um cloro. Estas substituições aumentam a ação antimicrobiana e diminuem a característica irritante do fenol. São considerados insolúveis em água e por isso os produtos à base de 
derivados de fenol precisam ser formulados com emulsificantes, como os tensoativos aniônicos e sabões (UNIVERSIDADE DE SÃO PAULO 2000).

O o-benzil-p-paraclorofenol é classificado como semi-volátil.

Os principais dados físico-químicos do o-benzil-p-clorofenol estão apresentados abaixo.

Fórmula estrutural:<smiles>O=[N+]([O-])Oc1ccccc1Cc1ccccc1O</smiles>

- Fórmula empírica: $\quad \mathrm{C}_{13} \mathrm{H}_{11} \mathrm{ClO}$

- Peso Molecular, PM:

218,7

- Ponto de fusão, PF:

$48,5^{\circ} \mathrm{C}$

- Ponto de ebulição, PE:

$160-162^{\circ} \mathrm{C}$

- Pressão de saturação de vapor, $P_{v}\left(100^{\circ} \mathrm{C}\right): 0,1 \mathrm{hPa}$

- Solubilidade $\left(20^{\circ} \mathrm{C}\right)$

- Água: $\quad 0,4 \mathrm{~g} / 1$

- Etanol: $\quad>3000 \mathrm{~g} / \mathrm{l}$

- $\mathrm{NaOH} 10 \%$ : $1000 \mathrm{~g} / \mathrm{l}$

O o-fenilfenol tem aparência cristalina, cor branca e odor suave característico. É insolúvel em água. São sinônimos: o-bifenilol, 2-bifenilol ou 2-hidroxibifenil. De acordo com as fichas de segurança consultadas (DATA SHEET 1994; BUDAVARI 1996; DOWICIDE 1998; HTDOCS 1999).

Os principais dados físico-químicos do o-fenilfenol estão apresentados abaixo:

Fórmula estrutural:

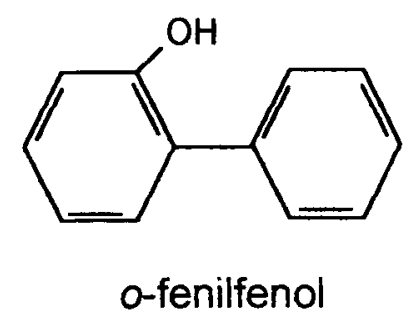


Fórmula empírica:

$\mathrm{C}_{12} \mathrm{H}_{10} \mathrm{O}$

Peso Molecular, PM:

170,2

Pressão de saturação de vapor $P_{v}\left(163^{\circ} \mathrm{C}\right)$ :

$2,7 \mathrm{kPa}$

$\left(20^{\circ} \mathrm{C}\right)$ :

$0,0017 \mathrm{mmHg}$

Ponto de fusão, PF:

$55,5-57,5^{\circ} \mathrm{C}$

Ponto de Ebulição, PE:

$280-284^{\circ} \mathrm{C}$

\subsubsection{Compostos quaternários de amônio}

A característica dos compostos quaternários de amônio de interesse para esse estudo refere-se ao fato de se tratar de sais. Sais não se volatilizam, pois é necessária uma quantidade de energia muito grande para desprender compostos iônicos da fase líquida.

Dentre os produtos disponíveis no mercado, a maioria é de sais de cloreto, porém há ainda os sais de brometo e propionatos; são líquidos transparentes, viscosos, de cor clara a amarelada, de odor característico e solúveis em água.

O exemplo de sal de composto quaternário de amônio mais comum é o cloreto de alquildimetilbenzilamônio ou cloreto de benzalcônio, comercializado em soluções de 50 a $80 \%$ de ativo.

A fórmula estrutural pode ser representada conforme segue.

$$
\left[\begin{array}{c}
\mathrm{R}^{1} \\
\mathrm{R}^{2}-\mathrm{N}^{\mathrm{N}}-\mathrm{CH}_{3} \\
1 \\
\mathrm{CH}_{3}
\end{array}\right]^{+}
$$

$R^{1}$ e $R^{2}$ são cadeias carbônicas. Para o alquildimetilbenzilamônio, $R^{1}$ representa a cadeia alquílica que pode variar de 12 a 18 carbonos $\left(C_{12}\right.$ a $C_{18}$ ) e $R^{2}$, o radical benzil. 
O conhecimento das propriedades físico-químicas dos compostos orgânicos de ação antimicrobiana encontrados nas composições químicas dos produtos desinfetantes, foi tomado como base para a seleção do COV que será enfocado nesse estudo, bem como para a escolha dos métodos que irão compor a estratégia analítica do estudo.

Dentre os três tipos de sistemas bactericidas presentes nas composições químicas dos desinfetantes, o formaldeído é o único Composto Orgânico Volátil; os derivados de fenol, o-benzil p-clorofenol e o-fenilfenol são semivoláteis $e$ os sais quaternários de amônio: cloreto de dialquildimetilbenzilamônio e associação de cloreto de dialquildimetilbenzilamônio com cloreto de dialquildimetilamônio, são não-voláteis.

Aliada à alta volatilidade, a alta solubilidade do formaldeido em água, the confere um comportamento toxicológico importante em termos de irritação da mucosa, como será evidenciado no próximo item. Portanto, o formaldeído foi selecionado como o composto orgânico tóxico de maior relevância para se avaliar os desinfetantes de uso geral quanto à emissão de compostos orgânicos tóxicos.

\subsection{Perfil toxicológico do formaldeído}

O formaldeído é apontado em vários estudos como um importante fator de predisposição à irritação dos olhos e trato respiratório, particularmente de crianças (CASTEEL et. al. 1987; GOLD 1992). Pode causar laringite conforme o caso reportado por Roto e Sala (1996). Há inclusive evidências epidemiológicas de que a exposição ocupacional a formaldeído está associada ao risco de câncer no trato respiratório - sinonasal e nasofaríngeo - conforme o trabalho finiandês relatado por PARTANEN (1993).

Estudos ocupacionais indicam também que 1 a $2 \%$ da população exposta a altas concentrações de formaldeído podem desenvolver asma. Um estudo realizado nos Estados Unidos reportou que crianças expostas à concentração de 60 a $120 \mathrm{ppb}$ de formaldeído em casa e, principalmente se 
expostas também à fumaça de cigarro, têm tendência a sofrer de asma ou bronquite crônica (CRUMP 1995; WANTKE et. al. 1996).

O formaldeído é conhecido como um dos irritantes da mucosa mais poderosos; provocando dificuldade de respiração e reações alérgicas severas.

Em humanos, a exposição aguda ao formaldeído por inalação causa irritação nos olhos, no nariz e na garganta. Outros efeitos notados devido à exposição a altos níveis de formaldeído em humanos são: tosse, dificuldade em respirar, dores no peito e bronquite (EPA 1988; WHO 1989). Em humanos, a ingestão resultou em corrosão do trato gastrointestinal e inflamação e ulceração da boca, esôfago e estômago. Testes agudos em animais, tais como $\mathrm{CL}_{50}$ e $\mathrm{DL}_{50} \mathrm{em}$ ratos e coelhos, mostraram que 0 formaldeido causa toxicidade aguda (efeitos de curto prazo) por inalação, exposição oral e dérmica (RTECS 1993).

A exposição aguda, a $125 \mathrm{mg} / \mathrm{m}^{3}$ de formaldeído em média, pode ser fatal (CRUMB 1995), contudo, o limite de detecção olfativa é baixo o bastante para que a irritação dos olhos e das mucosas ocorra antes que estes níveis sejam atingidos (OSHA 2002).

Em humanos, a exposição crônica ao formaldeído por inalação tem sido associada a sintomas respiratórios e irritação dos olhos, nariz e garganta. Contatos repetidos com soluções de formaldeído resultaram em irritação da pele e dermatite de contato. Estudos em animais mostraram efeitos no epitélio nasal e lesões no sistema respiratório devido à exposição inalatória crônica, ou seja, de longo prazo (CALABRESE e KENYON 1991; HSDB 1993; EPA 1988; WHO 1989).

A USEPA classifica o formaldeído como provável carcinogênico para humanos, no grupo B1 (EPA 1988; EPA 1993).

Um aumento na incidência de desordens menstruais e problemas na gravidez foi observado em mulheres que trabalhavam com resinas de uréiaformaldeido. Um estudo realizado com trabalhadores que esterilizam 
equipamentos hospitalares não mostrou associação entre exposição a formaldeído e aumento da absorção. Defeitos congênitos não foram observados em estudos com animais (EPA 1988; WHO 1989).

O NIOSH recomenda que o formaldeído seja tratado como um potencial carcinogênico ocupacional e que controles apropriados sejam usados para reduzir a exposição dos trabalhadores. Estas recomendações são baseadas num estudo do CIIT (Chemical Industry Institute of Toxicology), no qual ratos de laboratório e camundongos expostos a vapores de formaldeído, desenvolveram câncer nasal. Esses resultados são ainda apoiados pela Universidade de Nova lorque, em cujos estudos, ratos expostos à mistura de vapores de formaldeído e ácido cloridrico desenvolveram câncer nasal. Há evidências de mutagenicidade em vários estudos de laboratório. Em adição ao potencial carcinogênico, outros efeitos adversos à saúde são descritos. $\mathrm{O} N \mathrm{NISH}$ recomenda que os fabricantes e distribuidores de formaldeído, e de substâncias e materiais contendo formaldeido, repassem estas informações aos seus empregados e clientes e que as associações de profissionais informem os seus membros (NIOSH 1981).

O primeiro relato de evidências de carcinogenicidade para o formaldeído foi feito em outubro de 1979. Dados preliminares de estudos, ainda em andamento, em ratos e camundongos patrocinados pelo CIIT, indicaram que para exposições de 15 ppm por 6 horas/dia, 5 dias por semana por 16 meses, o formaldeído se mostrou carcinogênico para ratos. Alguns ratos desenvolveram câncer no $12^{\circ}$ mês. $O$ estudo conduzido pelo laboratório Batelle Columbus segue o protocolo da CIIT usando ratos Fischer e camundongos $\mathrm{B} 6 \mathrm{C} 3 \mathrm{~F} 1$, expostos em grupos de 120 animais de cada sexo, a três niveis de exposição, mais os controles, 6 horas por dia, 5 dias por semana. $O$ estudo expōs animais de ambas as espécies a concentrações de vapor de formaldeído de 15, 6 e 2 ppm. Após 6 meses de exposição a 15 ppm, três ratos desenvolveram carcinoma em células squamous, um tipo de célula originado no epitélio nasal. Um quarto caso de carcinoma do septo nasal desenvolveu-se no grupo exposto a 6 ppm, contudo esse câncer pode 
ter sido originado em outra camada da pele do nariz, que não o septo nasal (US NATIONAL ACADEMY OF SCIENCES 1993).

A IARC recomenda como parte da política de carcinogênicos, que respiradores de alta proteção sejam utilizados quando a concentração de formaldeído for acima de 0,016 ppm. Já a OSHA (29 CFR 1910.1048) recomenda que sejam fornecidos aos trabalhadores, respiradores altamente protetores para concentrações maiores que $75 \mathrm{ppm}$, valor equivalente a cem vezes o limite OSHA PEL de $0,75 \mathrm{ppm}$.

Seguem outros dados toxicológicos e classificações de risco.

- Classificação de risco EPA: Grupo B1 (provável carcinogênico humano de risco médio).

- Concentração Letal Inalatória $\left(\mathrm{CL}_{50}\right)$ :

- Camundongo: 333 ppm

- Rato: 815 ppm

- IARC / WHO (Monography Vol. 62, 1997 p. 217): Grupo 2A (provável carcinogênico para humanos)

Houve produção de carcinomas após exposição a $14,1 \mathrm{ppm}$ em camundongos e 5 e $6 \mathrm{ppm}$ em ratos por $6 \mathrm{~h} / \mathrm{dia}, 5$ dias/semana por 24 meses).

- NOEL: $2,5 \mathrm{mg} / \mathrm{m}^{3}$ (em relação à proliferação celular e danos a tecidos, efeitos que contribuem para o desenvolvimento de cáncer em animais). Exposição aguda ou subaguda: danos ao epitélio nasal e aumento significativo de tum over celular não detectáveis em ratos; exposição subcrônica ou crônica: a taxa de turn over celular no septo nasal de ratos não aumentou.

Os principais limites de exposição ocupacional ao formaldeído são apresentados abaixo.

- Limite de Tolerância / Brasil: 2,3 mg/m ou 1,6 ppm. 
Tendo em vista que esta legislação é antiga (Norma Regulamentadora NR - 15 - Lei № 6.514 de 22/12/1977 do Ministério do Trabalho), portanto os valores encontram-se desatualizados e, sob o ponto de vista ético e científico, devem ser empregados com cautela, apenas em casos que envolvem questões legais.

- NIOSH REL - TWA: 0,015 ppm ou 0,1 ppm (15 minutos).

O NIOSH considera o formaldeído, um potencial carcinogênico ocupacional, como definido na política OSHA para carcinogênicos [29 CFR 1990].

- Limite de tolerância - TWAACGIH: 0,3 ppm ou $0,37 \mathrm{mg} / \mathrm{m}^{3} / \mathrm{A} 2$. Substância classificada no Grupo A2 (suspeita de carcinogênese humana). Segundo a NR-9, os limites da $A C G I H$ devem ser utilizados na ausência de limites na NR-15.

- OSHA PEL (29 CFR 1910.1048, 1997):
- TWA:
$0,75 \mathrm{ppm}$
- STEL:
$2 \mathrm{ppm}$

- MAK: 0,5 ou $0,6 \mathrm{mg} / \mathrm{m}^{3} / \mathrm{B}$.

(Maximale arbeitsplatzkonzentrationen), 1995.

Picos de exposição de até 2 MAK por 5 minutos, 8 vezes ao dia. Substância classificada na grupo B (potencialmente carcinogênica).

Obs.: Legislação alemã, a qual apresenta indicações para exposição de curta duração para quase todas as substâncias; limites atualizados e bem fundamentados.

Para fins de comparação dos resultados de avaliação ambiental com os respectivos limites de exposição, deve-se levar em conta os diversos fatores intervenientes na exposição de um trabalhador a um dado agente químico. 
Os limites devem ser tomados como guia ou orientação e não como uma linha divisória entre uma condição segura e outra de risco. É preciso observar ainda que os limites de exposição são estabelecidos para substâncias puras, fato que dificilmente se observa na prática. Portanto, é necessário considerar a interação de efeitos tóxicos nas misturas utilizadas e outros agentes químicos e físicos presentes. Não se pode desconsiderar as implicações relativas à freqüência e duração da exposição e da jornada de trabalho, que podem aumentar ou diminuir a absorção. Deve-se ainda estudar as implicações da exposição alternada com outras substâncias ou agentes.

Freqüentemente, o formadeído é citado como uma substância natural, presente no metabolismo das células do corpo humano e encontrado em frutas tais como maçã e pera. Este argumento geralmente é apresentado para justificar que o formaldeído pode ser utilizado em produtos alimentícios ou para aplicação na pele como cosméticos, na concentração máxima como formaldeído livre de $0,1 \%$ em produtos de uso oral e até $0,2 \%$ em produtos cosméticos devido ao seu efeito sensitizante e irritante de acordo com o Final Report on the Safety Assessment of Formaldehyde publicado no Joumal of the American College of Toxicology em 1984 (STEINBERG 1996).

Entretanto, neste estudo, a preocupação não se refere ao efeito sensitizante e irritante por contato da solução de formaldeído com a pele, mas sim ao risco da entrada desse composto no organismo humano na forma de gás, na qual pode ser introduzido no sistema respiratório superior, podendo vir a causar câncer. Esta preocupação se deve ao fato da maior parte do formaldeido ao qual as pessoas estão expostas, estar presente no ar, conforme alertado pela ATSDR (1999), que é a agência do Departamento de Saúde e Serviços Humanos dos Estados Unidos. 
1, que apresenta os princípios ativos autorizados na legislação sanitária em vigor: aldeídos, fenólicos, quaternários de amônio, compostos inorgânicos doadores de cloro ativo, compostos orgânicos doadores de cloro ativo, iodo e derivados, álcoois e glicóis, biguanidas e outros. Dentre esses princípios ativos, destacam-se para fins desse estudo, os aldeídos: formaldeído, glioxal, glutaraldeído e paraformaldeído.

O subanexo 2 da Portaria MS № 15/1988 define os microorganismos para avaliação da ação antimicrobiana dos produtos. Para desinfetantes de uso geral, os microorganismos exigidos são: Staphylococcus aureus e Salmonella choleraesuis.

O subanexo 3 da Portaria MS № 15/1988 estabelece os dados toxicológicos agudos exigidos para $\circ$ registro de produtos com princípios ativos autorizados. Para os desinfetantes de uso geral, consta: irritabilidade dérmica e irritabilidade ocular. É prerrogativa do órgão competente, a solicitação de ensaios agudos complementares, conforme o subanexo 4 da mesma portaria, quando julgado necessário à correta avaliação do produto.

Os testes para avaliação toxicológica são os seguintes:

- toxicidade aguda por via oral para ratos, com valores de $\mathrm{DL}_{50}$ e descrição dos sintomas observados;

- toxicidade aguda por via dérmica para ratos, com valores de $D_{50}$ e descrição dos sintomas observados;

- toxicidade aguda por via inalatória para ratos, com valores de $\mathrm{CL}_{50}$ e descrição da sintomatologia observada;

- testes de irritabilidade da pele e olhos em coelhos, sendo dispensável no caso de produtos com pH igual ou inferior a 2 , ou igual ou superior a 11,5 , enquadrados automaticamente na classe de risco I (corrosivos);

- teste de sensibilização dérmica em cobaias;

- testes para verificação de mutagenicidade "in vitro" e "in vivo";

- teste de toxicidade sub-crônica (90 dias) via oral, em ratos;

- teste para avaliação do metabolismo e excreção, em ratos;

- teste para verificação de efeitos teratogênicos em ratos e coelhos; 
- teste para verificação de efeitos carcinógenos em camundongos e ratos, via oral, com duração não inferior a 18 e 24 meses, respectivamente;

- teste para avaliação de toxicidade crônica, via oral, com espécie roedora e outra não roedora;

- teste para verificação de efeitos nocivos ao processo reprodutivo, em ratos, por, no mínimo, 2 gerações;

- teste para verificação de toxicidade dérmica sub-aguda (21 dias), em ratos ou coelhos;

- teste para verificação de toxicidade inalatória sub-aguda (14 e 21 dias), em ratos;

- teste para verificação de toxicidade dérmica sub-crônica (noventa dias) em coelhos ou ratos;

- teste para verificação de neurotoxicidade retardada;

- testes complementares para enzimas especificas e

- dados sobre o emprego de antídotos, antagonistas e primeiros socorros para os casos de intoxicação.

Dentre as exigências referentes aos dizeres de rotulagem, esta norma exige que os princípios ativos sejam declarados pelos seus nomes químicos ou técnicos e os respectivos teores, no painel principal, em destaque.

\subsubsection{Em relação ao controle da Qualidade do Ar Interior}

A Portaria MS № 3.523 , de 28 de agosto de 1998 estabelece o regulamento técnico que contém as medidas básicas referentes aos procedimentos de verificação visual do estado de limpeza, remoção de sujidades por métodos físicos e manutenção do estado de integridade e eficiência dos componentes dos sistemas de climatização, para garantir a qualidade do ar de interiores e prevenção de riscos à saúde aos ocupantes de ambientes climatizados. A efetiva aplicação dessa portaria se deu com a publicação da Resolução № 176, de 24 de outubro de 2000. Esta resolução fornece orientação técnica contendo padrões referenciais de Qualidade do Ar 
Interior em ambientes de uso público e coletivo, climatizados artificialmente. A resolução recomenda o índice máximo de poluentes de contaminação biológica e química, além de parâmetros físicos do ar interior e prevê ainda métodos analíticos e recomendações para controle e correção, caso os padrões de ar forem considerados regulares ou ruins.

Os padrões referenciais adotados complementam então as medidas básicas definidas na Portaria MS № 3.523/98, de 28 de agosto de 1998, para efeito de reconhecimento, avaliação e controle da QAl nos ambientes climatizados. Deste modo poderão subsidiar as decisões do responsável técnico pelo gerenciamento do sistema de climatização, quanto à definição de periodicidade dos procedimentos de limpeza e manutenção dos componentes do sistema.

Esta resolução estabelece que a Taxa de Renovação do Ar adequada para ambientes climatizados será, no minimo, de $27 \mathrm{~m}^{3} / \mathrm{hora} /$ pessoa, exceto no caso especifico de ambientes como lojas, centros comerciais, bancos e outros, onde a taxa de ocupação de pessoas por metro quadrado é crítica. Nestes casos, a Taxa de Renovação do Ar mínima será de 17 $\mathrm{m}^{3} /$ hora/pessoa, não sendo admitido em qualquer situação que os ambientes possuam uma concentração de $\mathrm{CO}_{2}$ maior ou igual à estabelecida nesta Orientação Técnica como Valor Máximo Recomendável. O grau de pureza do ar em relação a poeira nos ambientes climatizados será obtido utilizando-se, no mínimo, filtros de classe G-3 nos condicionadores de sistemas centrais.

Esta Resolução define como ambientes aceitáveis, os ambientes livres de contaminantes em concentraçōes potencialmente perigosas para a saúde dos ocupantes ou que apresentem um mínimo de $80 \%$ dos ocupantes destes ambientes sem queixas ou sintomatologia de desconforto e como Qualidade do Ar Interior, a condição resultante do processo de ocupação de um ambiente fechado, com ou sem climatização artificial; estabelece ainda as possíveis fontes de poluentes químicos conforme descrito no anexo 2. A lista de poluentes inclui os de maior ocorrência nos ambientes interiores, 
cujos efeitos na saúde humana, são mais conhecidos e de mais fácil detecção.

Instituído pela Lei 8.078 de setembro de 1990, o Código Brasileiro de Defesa do Consumidor é um instrumento legal cujos dispositivos devem ser também considerados na comercialização de produtos de limpeza. Os direitos reservados ao consumidor, referentes a advertências em relação a riscos, dizeres de rotulagem em linguagem clara e letra legivel, composição química declarada etc., requerem cuidados por parte do fabricante na elaboração do rótulo, pois o consumidor tem o direito à informação sobre o produto que adquire (GRINOVER 2000).

Finalmente, cabe comentar aqui a recente criação do Sistema Nacional de Vigilância Ambiental em Saúde (SINVAS) regulamentado pela Fundação Nacional de Saúde (FUNASA) por meio da Instrução Normativa № 01 de 25 de setembro de 2001 (MINISTÉRIO DA SAÚDE 2001). O SINVAS está inserido no Sistema Único de Saúde (SUS) e tem um papel importante no contexto de Saúde do Brasil, que é de transição demográfica e epidemiológica, caracterizada pela intensa urbanização e prevalência das doenças e agravos relacionados à vida moderna. Sendo um dos objetivos do SINVAS, identificar as medidas de prevenção e controle dos fatores de riscos e das doenças ou outros agravos à saúde relacionados ao ambiente e às atividades produtivas, a questão da Prevenção da Poluição Química do Ar Interior the é muito pertinente.

O conjunto de temas exposto até aqui levanta algumas questões relevantes tanto para o cidadão como para os responsáveis pela fabricação de produtos, que vêm justificar a escolha desse estudo tais como: dentre os desinfetantes disponiveis no mercado atual, quais são os que menos comprometem a qualidade do ar interior? Que medidas podem ser adotadas para prevenir a poluição química do ar interior pelos desinfetantes e os produtos de limpeza em geral?

Nos próximos capítulos, estão encaminhadas as respostas para estas questōes. 


\section{OBJETIVOS}

\section{GERAL:}

Contribuir para o desenvolvimento e uso correto de produtos de limpeza que não venham a comprometer a Qualidade do Ar Interior.

\section{ESPECÍFICOS:}

1. Avaliar desinfetantes de uso geral quanto à emissão de formaldeído durante a desinfecção de sanitários;

2. Propor medidas de Prevenção da Poluição Química do Ar Interior em relação a produtos de limpeza como estratégia de redução de risco à saúde.

As hipóteses analisadas foram:

\section{HIPÓTESE 1:}

Alguns desinfetantes de uso geral atualmente disponíveis no mercado brasileiro apresentam riscos à saúde.

\section{HIPÓTESE 2:}

A prevenção da Poluição do Ar Interior no Brasil, em relação a produtos de limpeza, requer mudanças em termos de vigilância sanitária. 
Em princípio, a caracterização de fontes de emissão de COVs é mais simples do que a avaliação ambiental, pois esta exige cuidados especiais de amostragem. Foram desenvolvidos pela USEPA, alguns métodos para medir COVs em concentraçōes da ordem de ppb. O Compêndio de Métodos para a Determinação de Compostos Orgânicos Tóxicos em Ar Ambiente (TO-14) descreve procedimentos para amostragem e análise de COVs via separação por cromatografia gasosa e determinação por espectrometria de massa ou por multidetectores (USEPA 1999).

As câmaras de teste, citadas em muitos estudos de determinação do potencial de volatilização de compostos orgânicos são conhecidas como FLEC (Field and Laboratory Exposure Chamber) e podem ser utilizadas para gerar um ambiente padrão para as mediçōes em QAl (ROACHE e HOWARD 1995; KREBS et. al. 1995). Trata-se de uma técnica de amostragem, na qual o perfil concentração-tempo pode ser expresso em $\mathrm{mg} / \mathrm{h}$ e normalizado para unidade de superficie ou peso de produto (COLOMBO et. al., 1991). A montagem nestas câmaras, que podem ser de pequeno ou grande porte, requer cuidados na escolha do material de construção e na padronização das condições de operação e da dinâmica do movimento de ar, conforme colocado por YOCOM e MCCARTHY (1994).

Estudos da taxa de emissão de poluentes podem ser feitos utilizando-se a técnica de head space, bastante citada nos trabalhos relacionados a COVs. As amostras são colocadas em recipiente fechado e os gases acumulados no espaço acima da superfície do líquido, podem ser coletados manual ou automaticamente e analisados à pressão atmosférica ou pressão reduzida, à temperatura ambiente ou mais elevada. A taxa de emissão do poluente por quantidade unitária de material pode ser calculada. Conforme descrito por YOCOM e MCCARTHY (1994), a técnica de head space é muito semelhante à abordagem por câmara de teste porém em menor escala.

Embora as técnicas de amostragem em câmaras de amostragem e análise por head space sejam úteis para avaliação de emissões, o resultado é dado para uma condição ideal e padronizada. Por isso, a avaliação ambiental 
geralmente é vista como uma técnica mais confiável e representativa uma vez que reproduz melhor a condição real. Para a realização desse estudo, inicialmente foi avaliada a aplicação do método de cromatografia gasosa com amostragem por head space. Foi testado o método manual na temperatura de $30^{\circ} \mathrm{C}$ e o método automático a $110^{\circ} \mathrm{C}$. A concentração de COVs nos produtos se mostrou muito baixa sendo altos os desvios obtidos nas réplicas. Em função das dificuldades e desvantagens encontradas na aplicação de amostragem por head space, conforme já haviam constatato COLOMBO et. al. (1990), esta técnica foi descartada.

Como técnica de identificação, a cromatografia é a única capaz de fornecer o espectro dos COVs (WALLACE 1995). Segundo BLUEMEN e BURNS (1995), um grande número de COVs pode ser separado e posteriormente identificado, utilizando-se três tipos de detectores. $O$ detector de espectrofotometria de massa, 0 de ionização de chama e o de captura de elétrons, conhecidos do Inglês abreviadamente como MS, FID e ECD, respectivamente. A escolha do melhor detector depende das características da amostra. $O$ formaldeído pode ser determinado por cromatografia gasosa com detector de ionização de chama $(F I D)$ e espectrofotometria de massa (MS) ou outros sistemas detectores, dependendo da forma de amostragem (WHO, 1997).

No presente estágio de conhecimento, estudos de medição da concentração de COVs totais no ar podem não ser muito úteis (WHO 1987). $\mathrm{Na}$ verdade, de acordo com BLOEMEN e BURN (1995), conhecer a concentração de COVs total de uma amostra de ar é de pouco interesse prático, uma vez que a maior parte de material carbônico disperso no ar, é constituída pelo metano, que é relativamente pouco tóxico e pouco reativo.

Durante a realização desse estudo, foi feita uma tentativa de determinação de COVs totais nos produtos, no laboratório da White Martins, através do método de cromatografia gasosa com coluna oca e detector de ionização de chama, visando determinar o conteúdo de compostos orgânicos expressos em unidades relativas ao metano, utilizado como padrão, conforme descrito 
na literatura (BLOEMEN e BURN 1995). Contudo os resultados obtidos não foram confiáveis, uma vez que a concentração para todos os produtos ficou abaixo da concentração de formaldeído determinada no liquido. Portanto, este trabalho teve como objetivo quantificar um COV específico, que foi selecionado como sendo o mais importante composto encontrado na composição química de desinfetantes de uso geral, quanto ao seu risco à saúde humana.

Além dos métodos cromatográficos, existe o método olfativo realizado por painel de pessoas treinadas (FÄNGER 1990) também citado por BLUEMEN e BURN (1995). Embora tenha caráter subjetivo, o tratamento estatístico aplicado ao planejamento dos testes e aos dados obtidos, garante a obtenção de resultados, que podem ser muito úteis para programas de monitotamento da qualidade do ar interior.

Os sensores químicos para análise de substâncias presentes no ar bem como os chamados "narizes químicos", que imitam o sistema olfativo humano, vêem sendo testados. Estes aparelhos são muito práticos e a tendência é que se tornem cada vez mais comuns, pois diversas classes de sensores mais sensíveis e confiáveis estão sendo lançados (GIODA e AQUINO NETO 2001).

O laboratório da USEPA - NRMRL (National Risk Management Research Laboratory) da seç̧ão de Gerenciamento Ambiental Interior sob a coordenação do Dr. Bruce Henschel, está trabalhando na pesquisa de métodos analíticos químicos para previsão de emissões de COV em fase gasosa, conforme apresentação realizada em reunião recente sobre o programa Buy Clean (HENSCHEL 2001).

Os laboratórios de análise prestadores de serviço pesquisados com vistas à cooperação em recursos analíticos para este estudo, foram os listados no Guia de análises 2000 da revista Química e Derivados e outros tais como Environlab, Ladetec, Instituto Tecnológico Mackenzie, T\&E Analítica, CEIMIC, Labservice, Centrais Analíticas do Instituto de Química da USP e UNICAMP, e outros. Finalmente, os resultados analíticos deste estudo 
na literatura (BLOEMEN e BURN 1995). Contudo os resultados obtidos não foram confiáveis, uma vez que a concentração para todos os produtos ficou abaixo da concentração de formaldeído determinada no líquido. Portanto, este trabalho teve como objetivo quantificar um COV específico, que foi selecionado como sendo o mais importante composto encontrado na composição química de desinfetantes de uso geral, quanto ao seu risco à saúde humana.

Além dos métodos cromatográficos, existe o método olfativo realizado por painel de pessoas treinadas (FÄNGER 1990) também citado por BLUEMEN e BURN (1995). Embora tenha caráter subjetivo, o tratamento estatístico aplicado ao planejamento dos testes e aos dados obtidos, garante a obtenção de resultados, que podem ser muito úteis para programas de monitotamento da qualidade do ar interior.

Os sensores químicos para análise de substâncias presentes no ar bem como os chamados "narizes químicos", que imitam o sistema olfativo humano, vêem sendo testados. Estes aparelhos são muito práticos e a tendência é que se tornem cada vez mais comuns, pois diversas classes de sensores mais sensíveis e confiáveis estão sendo lançados (GIODA e AQUINO NETO 2001).

O laboratório da USEPA - NRMRL (National Risk Management Research Laboratory) da secção de Gerenciamento Ambiental Interior sob a coordenação do Dr. Bruce Henschel, está trabalhando na pesquisa de métodos analíticos químicos para previsão de emissões de COV em fase gasosa, conforme apresentação realizada em reunião recente sobre o programa Buy Clean (HENSCHEL 2001).

Os laboratórios de análise prestadores de serviço pesquisados com vistas à cooperação em recursos analíticos para este estudo, foram os listados no Guia de análises 2000 da revista Química e Derivados e outros tais como Environlab, Ladetec, Instituto Tecnológico Mackenzie, T\&E Analítica, CEIMIC, Labservice, Centrais Analíticas do Instituto de Química da USP e UNICAMP, e outros. Finalmente, os resultados analíticos deste estudo 
foram obtidos com a participação do laboratório da Lonza do Brasil Ltda, para as análises de determinação de formaldeído, e da Toxikon Higiene Industrial, para as amostragens $e$ análises relativas às avaliações ambientais.

\subsection{Amostragem dos produtos no mercado}

A coleta de produtos no mercado se deu em três etapas: maio de 2001, janeiro e abril de 2002, sendo que na primeira procurou-se verificar a qualidade dos dados obtidos, a eficácia e adequação dos métodos e técnicas de análise química utilizados, antes de se prosseguir, tendo sido adquiridos os 3 produtos em cujos rótulos constava o formaldeído declarado no item composição química, de forma qualitativa ou quantitativa. Estes produtos eram também os que se encontravam posicionados na gôndola à altura da vista do consumidor, local que é tradicionalmente dedicado às marcas mais vendidas.

$\mathrm{Na}$ segunda etapa, coletou-se mais 5 produtos que traziam a denominação preservante ou coadjuvante declaradas no rótulo, indicando indiretamente a provável presença de formaldeído.

$\mathrm{Na}$ última etapa, decidiu-se abranger todas as marcas de desinfetantes de uso geral encontradas, coletando mais 9 produtos, mesmo não havendo nenhuma alusão a formaldeído no rótulo, uma vez que através das análises de determinação de formaldeído, vinha-se constatando a presença desse COV em todos os produtos. No total, foram coletados 17 produtos, os quais fizeram parte do estudo. Estas marcas são distribuídas em todo o território nacional, pois seus fornecedores atuam no mercado de todo o país, o que amplia o alcance das conclusões desse estudo, ainda porque o tipo de fórmula de desinfetante de uso geral praticada no mercado, varia pouco de um fabricante para outro.

A coleta de produtos foi realizada no mercado do grande varejo da Região Metropolitana de São Paulo (RMSP) nas redes de supermercado Carrefour 
e Extra. Foram buscadas as marcas de desinfetante de uso geral atualmente à venda, encontrados na gôndola, agrupados como desinfetantes e que continham no painel frontal do rótulo a denominação "desinfetante", apresentados em frascos de qualquer tamanho (500, 1000 ou $2000 \mathrm{~mL}$ ), exceto:

- as marcas próprias dos supermercados, devido à oscilação de distribuição no mercado, ou seja, ocasionalmente falta produto ou ocorre mudança de fabricante, que é terceirizado;

- os desinfetantes à base de cresol, apresentados em lata (folha de flandres), que devido ao odor extremamente forte e irritante, não são utilizados em ambientes interiores.

Cabe lembrar, que existem produtos clandestinos no mercado. Por falta de uma atuação efetiva das autoridades, via conscientização e fiscalização, a informalidade tem sido uma realidade no mercado de produtos de limpeza. $\mathrm{Na}$ estimativa da ABIPLA, cerca de $30 \%$ dos desinfetantes existentes no mercado brasileiro são clandestinos. (ABIQUIM 2002; AMARAL 2002). São desinfetantes que não têm registro no Ministério da Saúde; podem ser adquiridos por venda a granel ou em pequenas lojas, acondicionados em embalagens reutilizadas de refrigerantes e outras embalagens compostas de resina de polietilenotereftalato (PET). A Vigilância Sanitária iniciou em 2002 uma campanha de combate em conjunto com a ABIPLA, contando com ações de fiscalização e conscientização. Estes produtos não foram considerados no presente estudo.

Cada produto recebeu um código através do qual foi referenciado ao longo deste trabalho. Este código é composto de dois dígitos: um número de 1 a 3 , indicando a etapa de amostragem, e uma letra, identificando o produto.

Foram adquiridos 3 litros de cada desinfetante, do mesmo lote, de tal maneira que a quantidade permitisse que o levantamento de dados e a parte experimental fossem realizados com exatamente a mesma composição química, visando o correlacionamento dos dados obtidos e a garantia da qualidade dos resultados e comparaçōes. Os produtos foram 
codificados por um número, indicando a etapa de coleta de mercado, seguido de uma letra de acordo com a quantidade de amostras adquiridas.

Adotou-se uma versão por produto nos casos de composições que variam apenas em perfume e corante. Foi adquirido então o total de 17 produtos para este estudo.

\subsection{Seleção do principal composto orgânico tóxico}

Nesta etapa, efetuou-se o levantamento dos dados e informações declarados no rótulo pelos fabricantes de cada um dos produtos amostrados. $O$ resultado foi tabelado e analisado.

A fim de selecionar o(s) $\operatorname{COV}(\mathbf{s})$ mais tóxico(s) presente(s) nos desinfetantes de uso geral amostrados, o levantamento de dados sobre as composições qualitativa e quantitativa declaradas foi direcionado para os principios ativos de ação antimicrobiana, pela inerente toxicidade que apresentam. Estes desempenham as funçōes de bactericida e conservante na composição química do produto. Além da toxicidade, utilizou-se como critérios de seleção, a freqüência de utilização nos diferentes produtos amostrados e a volatilidade, tendo como referência os dados físico-químicos dos princípios ativos obtidos da literatura na fase de revisão bibliográfica deste estudo.

Foram extraídas dos rótulos também as informações sobre o modo de uso de cada produto, que serviram de base para definir as condições do ambiente para teste.

\subsection{Determinação de formaldeído nos produtos}

Uma vez selecionado o formaldeído como o principal composto orgânico volátil presente na composição química dos produtos estudados, foram programadas as análises químicas necessárias para a confirmação da concentração de formaldeido total nos produtos. 
A concentração de formaldeído total nos produtos representa o potencial de emissão de formaldeído total dos produtos numa situação em que todo o composto se volatilizasse, passando para 0 ar. Há três justificativas para este cuidado: o componente declarado genericamente como preservante poderia ser o formaldeído; nos casos em que o formaldeído é declarado quantitativamente e, a concentração praticada poderia estar diferindo da declarada.

A determinação da concentração total de formaldeído foi feita através de titulação automática com ácido sulfúrico $0,5 \mathrm{M}$ padronizado, em presença de hidróxido de potássio $0,5 \mathrm{M}$ e peróxido de hidrogênio $7 \%$. 0 procedimento é, resumidamente, o seguinte:

a. Pesar a amostra num balão de fundo redondo cerca de $50 \mathrm{~mL}$ de água destilada;

b. Adicionar $50 \mathrm{~mL}$ de água destilada num outro frasco (branco);

c. Numa proveta graduada de $25 \mathrm{~mL}$, adicionar $12-13 \mathrm{~mL}$ de solução de peróxido de hidrogênio $7 \%$;

d. Pipetar $40 \mathrm{~mL}$ de $\mathrm{KOH} 0,5 \mathrm{M}$ à amostra e ao branco;

e. Colocar em refluxo durante 20 a 25 minutos em manta aquecedora utilizando um condensador de refluxo (o cronômetro deve ser acionado quando da condensação da primeira gota);

f. Deixar esfriar até $40^{\circ} \mathrm{C}$ e transferir o conteúdo para um béquer de 400 $\mathrm{mL}$, enxaguando-o com água destilada;

g. Agitar a solução e deixar esfriar.

h. Para a titulação automática, iniciar o programa do aparelho e titular com ácido sulfúrico $0,5 \mathrm{M}$.

i. Para o cálculo do resultado, utiliza-se a diferença de volume obtido entre a amostra e o branco.

Obs.: Para titulação manual, medir $\mathrm{opH}$ durante todo o procedimento. Encerrar a titulação em pH final de 7,5. 
Cálculos: $\mathrm{HCHO}$ Total $\left.=\left(\mathrm{V}_{b}-\mathrm{V}_{\mathrm{a}}\right) \times \mathrm{V}_{\mathrm{H}_{2} \mathrm{SO}_{4}} \times \mathrm{f}_{\mathrm{c}} \times 3.003\right)-$ fator

$\mathrm{m}$

Onde:

$V_{b}=$ Volume do branco;

$\mathrm{V}_{\mathrm{a}}=$ volume de amostra

$\mathrm{VH}_{2} \mathrm{SO}_{4}=$ volume de ácido gasto na titulação $(\mathrm{mL})$

$f_{c}=$ fator de correção da padronização do ácido

$\mathrm{m}=$ massa de amostra $(\mathrm{g})$

fator $=$ desconsiderar para soluções diluídas.

Os equipamentos utilizados foram os seguintes: Titulador automático Mettler Toledo, modelo DL 50 Graphix, programa DG101; pHmetro Micronal, modelo B474; Balança analítica Mettler Toledo, modelo AB204-S Monobloc; manta aquecedora Nalgon.

\subsection{Método de amostragem de formaldeído}

A fim de verificar se o formaldeído encontrado na fase líquida dos produtos poderia ser emitido para o ar interior quando aplicado numa determinada condição de ventilação, temperatura e umidade, procedeu-se às amostragens ambientais.

\subsubsection{Definição das condições do ambiente}

Sendo o desinfetante um produto comumente utilizado em sanitários, este foi o ambiente escolhido para a pesquisa. A amostragem foi realizada em quatro sanitários de mesmo arranjo físico, volume de ar e tipo de ventilação; permaneceram fora de uso durante o teste e a freqüência de abertura das portas foi a mesma durante todo o teste, havendo uma circulação de 3 pessoas em média. Ver detalhes no anexo 1. 
Os testes foram realizados em sanitários, nos dias 04/01/02 (Etapa 1) e 05/03/02 (Etapa 2).

Sendo o edifício climatizado artificialmente, pôde-se fixar a condição de renovação de ar, temperatura e umidade. A vazão de ar nas duas etapas foi a mesma para cada banheiro e foi medida com o anemômetro Turbo Meter - Wind Speed Indicator - Davis Instruments devidamente calibrado em 0,3 $\mathrm{m}^{3} / \mathrm{s}$. O volume de ar dos sanitários foi calculado em $38 \mathrm{~m}^{3}$, resultando numa renovação de ar de até $28 \mathrm{~m}^{3} / \mathrm{h}$, admitindo-se fluxo laminar.

As amostragens foram realizadas à temperatura ambiente $\left(25^{\circ} \mathrm{C}\right.$ na etapa 1 e $25,3^{\circ} \mathrm{C}$ na etapa 2) e umidade relativa do ar de $70 \%$. Os resultados obtidos para a concentração de formaldeído no ar foram corrigidos para $25^{\circ} \mathrm{C}$ e $760 \mathrm{mmHg}$

O modelo e material das instalaçōes e do piso, e o tipo de construção dos sanitários são aqueles comumente empregados em residências. Simulou-se a atividade de uma dona de casa, empregada doméstica ou de empresa que realize limpeza e desinfecção de sanitários, de tal forma que se pode fazer inferências para os ocupantes do ambiente e trabalhadores.

Antes do teste, os sanitários foram previamente limpos, utilizando-se apenas água para garantir a ausência de outros gases e vapores como perfumes e solventes, provenientes de outros produtos de limpeza.

Duas faxineiras participaram do teste, após passarem por um treinamento para fins de padronização do método de aplicação. Procurou-se simular a situação real de uso dos produtos, adotando-se o método habitual de aplicação nas superfícies com pano de algodão embebido de produto, em condiçōes padronizadas. Foram consideradas as instruçōes de uso recomendadas pelo fabricante, conforme descrito sucintamente abaixo:

- local/superfície: piso, vaso sanitário/tampa e ralo, que são as superfícies potencialmente mais contaminadas;

- concentração do produto: puro;

- quantidade: foram utilizados 2 frascos de $500 \mathrm{~mL}$ em cada sanitário; 
- tempo: mínimo de 10 minutos de contato, que é o tempo recomendado em função do método de análise de eficácia requerido pelo Ministério da Saúde para fins de registro do produto e

- forma de aplicação do produto:

- no vaso sanitário: espalhou-se o líquido diretamente do frasco nas paredes interna e externa e na tampa, espalhando com um pano de algodão $80 \times 30 \mathrm{~cm}$;

- no piso: com pano de algodão pré-umedecido e rodo para fazer o espalhamento.

\subsubsection{Coleta das amostras}

O equipamento utilizado para a coleta das amostras utilizado é composto basicamente de bomba portátil, mangueira, cartucho e suporte (tripé para amostragem em ponto fixo ou presilha para amostragem pessoal).

Neste estudo, foram utilizadas bombas portáteis (Aircheck Sampler Modelo 224-PCX, R8 - SKC) calibradas com calibrador primário Buk para a vazão de $150 \mathrm{~m} / \mathrm{min}$. Na etapa 1 , foi utilizada a estratégia de amostragem em ponto fixo na altura da zona respiratória representando a situação de uma pessoa que permanecesse no local de maior possibilidade de exposição, durante todo o periodo de amostragem. Na etapa 2, foi utilizada a amostragem pessoal com a fixação da bomba portátil à faxineira durante o período de aplicação do produto e em seguida procedeu-se à coleta em ponto fixo na zona respiratória.

À mangueira de cada bomba portátil, foi acoplado o cartucho de amostragem: um tubo descartável de vidro contendo sílica-gel impregnada com 2,4-dinitrofenilhidrazina (2,4-DNFH ou DNFH, simplesmente) fabricado pela SKC Inc. nos Estados Unidos e disponível comercialmente. Os cartuchos foram mantidos sob refrigeração enquanto fora de uso. A montagem do equipamento de amostragem foi orientada na direção do fluxo de ar (de acordo com a seta gravada no tubo). 
Para garantir que o material de amostragem não se saturou, o que poderia significar um resultado mais baixo que o real, o cartucho de amostragem possui 2 secções de sílica-gel/DNFH (dual bed tube): uma frontal, de 300 $\mathrm{mg}$ e outra de $150 \mathrm{mg}$. Esse tipo de tubo é utilizado quando há possibilidade de perda de material da amostra de ar por saturação do elemento coletor (breakthrough), ou seja, quando a concentração de formaldeído no ar excede o limite de exposição da ACGIH para 8 horas em 10 vezes. A opção por esse tipo de cartucho, foi uma medida de garantir a confiabilidade dos resultados.

Para cobrir o período mínimo de $80 \%$ de uma jornada de trabalho, cada coleta teve a duração aproximada de 6 horas.

$\mathrm{Na}$ primeira etapa foram testados 3 produtos com a bomba instalada em ponto fixo e, na segunda etapa, mais 2 produtos, com amostragem pessoal durante a aplicação (10 a 20 minutos) e em seguida, procedeu-se à coleta em ponto fixo na altura da zona respiratória, continuando até o final da amostragem, totalizando aproximadamente 7 horas para todos estes produtos.

Após a coleta, os cartuchos utilizados e os brancos foram tampados, identificados e acondicionados contra choques e conservados em caixa de isopor durante $o$ transporte e depois a $4^{\circ} \mathrm{C}$ até a execução das análises a fim de evitar perdas do formaldeído amostrado.

\subsection{Método de determinação de formaldeído por HPLC nas amostras ambientais}

Para a determinação do formaldeído amostrado no ar, foi utilizado o método USEPA TO-11 modificado (USEPA, 1999a), o qual tem sido empregado em muitos trabalhos no mundo por apresentar boa sensibilidade $\mathrm{e}$ reprodutibilidade (GIODA e AQUINO NETO 2000a). O principio deste método consiste na combinação de uma técnica de via úmida com material sólido adsorvente. Assim, o formaldeído foi adsorvido em tubos de silica-gel 
impregnada com DNFH, conforme representado a seguir. Em seguida, procedeu-se à separação e análise do derivado de hidrazona, por cromatografia líquida de alto desempenho (HPLC) com detector de ultravioleta (UV) e padronização externa.

A reação de compostos carbonilicos orgânicos (aldeidos e cetonas) com a DNFH impregnada na sílica-gel ocorre na presença de ácido forte, como catalisador, formando o derivado de hidrazona, colorido e estável, conforme a reação representada a seguir.

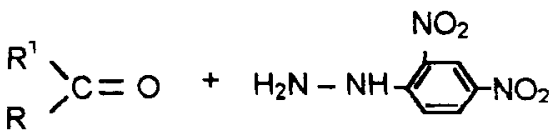

grupo carbonilico

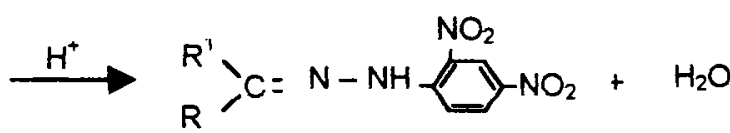

derivado de hidrazona

$R$ e $R^{1}$ são grupos orgânicos alquílicos ou aromáticos (cetonas) ou hidrogênio (aldeídos). Ocorre uma adição nucleofilica à carbonila seguida de eliminação de água, formando-se o derivado 2,4-dinitrofenilhidrazona. A determinação de formaldeído do derivado de DNFH-formaldeído é feita pelo método tradicional via HPLC.

Segue o resumo da descrição do método de determinação de formaldeído por HPLC no material amostrado.

a. Quebrar o tubo e colocar cada secçăo de material num frasco, adicionar $5 \mathrm{~mL}$ de acetonitrila e agitar por 30 minutos.

b. Preparar a solução estoque de DNFH $0,35 \mathrm{mg} / \mathrm{mL}$, pesando $35 \mathrm{mg}$ de DNFH e misturando a $100 \mathrm{~mL}$ de acetonitrila.

c. Preparar dois padrões para o HPLC, injetando 10 e $20 \mu \mathrm{L}$ da solução estoque acima em $5 \mathrm{~mL}$ de acetonitrila, o que corresponde a $0,05 \mu \mathrm{g}$ e $1,0 \mu \mathrm{g}$ de formaldeído por amostra.

d. Injetar cada solução em HPLC, coluna de fase reversa $\mathrm{C} 18$, isocrática, em duplicata, nas seguintes condições: 
- coluna: $250 \mathrm{~mm} \times 4,6 \mathrm{~mm}, 5$ mícron, Hypersil ODS.

- eluente: acetonitrila/água destilada $60 / 40$ a 1,0 mL/min.

- detector: UV operado a $365 \mathrm{~nm}$.

e. Calcular o fator de resposta médio ( $\mu \mathrm{g} / 5 \mathrm{~mL}$ área).

f. Para determinar a massa de formaldeído coletada, multiplicar a área média do pico do cromatograma de cada amostra pelo fator de resposta médio. Conhecido o fluxo de amostragem $\left(150 \mathrm{~m}^{3} / \mathrm{min}\right.$.) e o tempo de amostragem, calcula-se a concentração no ar em $\mathrm{mg} / \mathrm{m}^{3}$.

g. Para descontar do resultado obtido, o formaldeído e outros compostos carbonilicos que podem estar no material de amostragem, aplica-se o mesmo procedimento de dessorção e análise num cartucho branco, ou seja, não amostrado.

A eficiência de dessorção foi de $97,9 \pm 4,2 \%$ na faixa de 0,1 a 2,0 TWA com recuperação independente da concentração (amostras geradas por evaporação de quantidades conhecidas de padrões em tubo " $U$ ". Quanto à precisão do resultado, o coeficiente de variação total foi de 0,067 , obtido a partir dos resultados do teste de dessorção, da estabilidade da amostra coletada em freezer e da variação das bombas de coleta $(0,05)$.

O detalhamento completo do método pode ser obtido no relatório do Método TO-11A da USEPA (USEPA 1999a).

A interpretação dos resultados foi realizada com base nos dados toxicológicos e nos limites de exposição ocupacionais.

Foram tomadas todas as precauçōes necessárias para o sucesso das amostragens e análises bem como a precisão de todas as medidas. Em todas as etapas do trabalho foram empregados métodos validados e de acordo com as recomendações e protocolos do NIOSH/USA, OSHAUSA e ABNT. 


\subsection{Método de análise de aspectos da legislação sanitária}

A análise da legislação sanitária brasileira foi realizada com base nos aspectos mais pertinentes ao escopo desse estudo, que são as portarias referentes à regulamentação de produtos saneantes domissanitários de ação antimicrobiana, entre os quais se incluem os desinfetantes, e ao controle da qualidade do ar interior de ambientes climatizados artificialmente de uso público e privado.

Os métodos adotados foram pesquisa documental e análise comparativa.

A partir dos referenciais identificados na revisão dos temas sobre legislação pertinentes a esse estudo, os quais estão apresentados no capítulo Introdução, foi efetuada a comparação dos conteúdos e principalmente dos mecanismos reguladores das portarias e resoluções envolvidas. Procurouse identificar nestas portarias, os aspectos ligados a COVs e ao formaldeído, mais especificamente. 


\section{RESULTADOS E DISCUSSÃO}

Neste capítulo, são apresentados os resultados das pesquisas e testes realizados para a avaliação de desinfetantes de uso geral quanto à emissão de formaldeído, acompanhados da respectiva discussão.

\subsection{Dados e informações declarados nos rótulos dos produtos}

Após a leitura e análise dos rótulos de todos os produtos amostrados, foram extraídos os principais dados e informações declarados pelo fabricante, os quais foram reunidos na tabela abaixo.

Obs.: Para alguns componentes/produtos, as concentrações percentuais não são declaradas.

Tabela 2 - Principais dados e informações declarados nos rótulos dos produtos

\begin{tabular}{|c|c|c|c|c|}
\hline $\begin{array}{l}\text { Código } \\
\text { do } \\
\text { produto }\end{array}$ & $\begin{array}{l}\text { Principio } \\
\text { ativo }\end{array}$ & Composição & $\begin{array}{c}\text { Conc. } \\
(\%)\end{array}$ & Instruções de Uso \\
\hline $1 \mathrm{~A}$ & $\begin{array}{l}\text { Derivados de } \\
\text { Fenol }\end{array}$ & $\begin{array}{l}\text { o-benzil p-cloro- } \\
\text { fenol } \\
\text { Formaldeido } \\
\text { Óleo de pinho } \\
\text { Perfume } \\
\text { Sabão } \\
\text { Corante } \\
\text { Água q.s.p. }\end{array}$ & $\begin{array}{l}1,00 \\
0,40\end{array}$ & $\begin{array}{l}\text { Puro: aplicar o produto e deixar } \\
\text { agir por } 10 \text { minutos. } \\
\text { Diluido: diluir uma colher de sopa } \\
\text { do produto em um litro de água e } \\
\text { aplicar. }\end{array}$ \\
\hline $1 B$ & $\begin{array}{l}\text { Derivados de } \\
\text { Fenol }\end{array}$ & $\begin{array}{l}\text { o-benzil p-cloro- } \\
\text { fenol } \\
\text { o-fenilfenol } \\
\text { Formaldeído } \\
\text { Seqüestrante } \\
\text { Sabão } \\
\text { Óleo de Pinho } \\
\text { Corante } \\
\text { Estabilizante } \\
\text { Água q.s.p. }\end{array}$ & $\begin{array}{l}0,25 \\
0,50\end{array}$ & $\begin{array}{l}\text { Desinfeccão: aplicar puro e deixar } \\
\text { agir por } 10 \text { minutos. } \\
\text { Limpeza geral de superficies: diluir } \\
\text { duas colheres de sopa do produto } \\
\text { em um litro de água e aplicar. }\end{array}$ \\
\hline
\end{tabular}


Tabela 2 - Principais dados e informações declarados nos rótulos dos produtos, continuação:

\begin{tabular}{|c|c|c|c|c|}
\hline $\begin{array}{l}\text { Código } \\
\text { do } \\
\text { produto }\end{array}$ & $\begin{array}{l}\text { Principio } \\
\text { ativo }\end{array}$ & Composição & $\begin{array}{c}\text { Conc. } \\
(\%)\end{array}$ & Instruçōes de Uso \\
\hline $1 \mathrm{C}$ & Formaldeido & $\begin{array}{l}\text { Formaideido } \\
\left(\text { sol } 37^{\circ} \mathrm{C}\right) \\
\text { Dodecilbenzeno- } \\
\text { sulfonatode sódio } \\
(12 \%) \\
\text { Perfume } \\
\text { Água q.s.p. }\end{array}$ & & $\begin{array}{l}\text { Desinfecção: aplicar puro em } \\
\text { lixeiras, latas de lixo e ralos. } \\
\text { Deixar agir por } 10 \text { minutos. } \\
\text { Limpeza Geral: diluir } 1 \text { copo do } \\
\text { produto em um litro de água. }\end{array}$ \\
\hline $2 A$ & $\begin{array}{l}\text { Quaternário } \\
\text { Amônio }\end{array}$ & $\begin{array}{l}\text { Cl dialquil dimetil- } \\
\text { benzil amônio } \\
\text { Cl dialquil dimetil- } \\
\text { amônio }(100 \%) \\
\text { Perfume } \\
\text { Não lônico } \\
\text { Sequestrante } \\
\text { Corante } \\
\text { Preservante } \\
\text { Água q.s.p. }\end{array}$ & 0,50 & $\begin{array}{l}\text { Desinfeccáa: aplicar puro em } \\
\text { vasos sanitários, ralos, latas de } \\
\text { lixo. Deixar agir por } 10 \text { minutos. } \\
\text { Limpeza: diluir duas colheres de } \\
\text { sopa do produto em um litro de } \\
\text { água. Aplicar em pisos, azulejos, } \\
\text { esmaltados, banheiros es e } \\
\text { mármores. }\end{array}$ \\
\hline $2 B$ & $\begin{array}{l}\text { Quaternário } \\
\text { Amónio }\end{array}$ & $\begin{array}{l}\text { Cl dialquil dimetil- } \\
\text { benzil amónio } \\
\text { Cl dialquil dimetil- } \\
\text { amônio (100\%) } \\
\text { Seqüestrante } \\
\text { Opacificante } \\
\text { Preservante } \\
\text { Acidulante } \\
\text { Perfume } \\
\text { Água q.S.p. }\end{array}$ & 0,50 & $\begin{array}{l}\text { Desinfeccão: aplicar puro em } \\
\text { vasos sanitários, ralos, latas de } \\
\text { lixo. Deixar agir por } 10 \text { minutos. }\end{array}$ \\
\hline $2 \mathrm{C}$ & $\begin{array}{l}\text { Quaternário } \\
\text { Amônio }\end{array}$ & $\begin{array}{l}\text { Cl dialquil dimetil- } \\
\text { benzil amónio }(80 \%) \\
\text { Perfume } \\
\text { Não lônico } \\
\text { Coadjuvante } \\
\text { Corante } \\
\text { Água g.s.p. }\end{array}$ & 2,50 & $\begin{array}{l}\text { Desinfeccão: aplicar puro em } \\
\text { superfícies laváveis. Deixar agir } \\
\text { por } 10 \text { minutos. } \\
\text { Limpeza geral: diluir duas colheres } \\
\text { de sopa do produto em um litro de } \\
\text { água e aplicar. }\end{array}$ \\
\hline 2D & $\begin{array}{l}\text { Quaternário } \\
\text { Amônio }\end{array}$ & $\begin{array}{l}\text { Cl dialquil dimetil- } \\
\text { benzil amônio (80\%) } \\
\text { Perfume } \\
\text { Não lônico } \\
\text { Corante } \\
\text { Coadjuvante } \\
\text { Água q.s.p. }\end{array}$ & 1,00 & $\begin{array}{l}\text { Desinfeccão: aplicar puro em } \\
\text { vasos sanitários e ralos. Deixar } \\
\text { agir por } 10 \text { minutos. } \\
\text { Limpeza Geral: diluir } 2 \text { tampas em } \\
\text { um litro de água e aplicar em } \\
\text { superfícies laváveis. }\end{array}$ \\
\hline $2 E$ & $\begin{array}{l}\text { Quaternário } \\
\text { Amônio }\end{array}$ & $\begin{array}{l}\text { Cl dialquil dimetil- } \\
\text { benzil amônio }(50 \%) \\
\text { Perfume } \\
\text { Não lônico } \\
\text { Ópacificante } \\
\text { Água q.S.p. }\end{array}$ & 0,60 & $\begin{array}{l}\text { Desinfecçäo: aplicar puro. Deixar } \\
\text { agir por } 10 \text { minutos, enxaguando } \\
\text { em seguida. } \\
\text { Limpeza: diluir } 3 \text { colheres de sopa } \\
\text { em } 1 \text { litro de água. }\end{array}$ \\
\hline
\end{tabular}


Tabela 2 - Principais dados e informações declarados nos rótulos dos produtos, continuação:

\begin{tabular}{|c|c|c|c|c|}
\hline $\begin{array}{l}\text { Código } \\
\text { do } \\
\text { produto }\end{array}$ & $\begin{array}{l}\text { Principio } \\
\text { ativo }\end{array}$ & Composição & $\begin{array}{c}\text { Conc. } \\
(\%)\end{array}$ & Instruções de Uso \\
\hline $3 A$ & $\begin{array}{l}\text { Quaternário } \\
\text { Amônio }\end{array}$ & $\begin{array}{l}\text { Cl. dialquil dimetil- } \\
\text { benzil amônio }(50 \%) \\
\text { Perfume } \\
\text { Não lônico } \\
\text { Corante } \\
\text { Água q.S.p. }\end{array}$ & & $\begin{array}{l}\text { Desinfecção: aplicar puro em } \\
\text { vasos sanitários. Deixar agir por } \\
10 \text { minutos. } \\
\text { Limpeza: diluir duas colheres de } \\
\text { sopa em } 1 \text { litro de água e aplicar. }\end{array}$ \\
\hline 3B & $\begin{array}{l}\text { Quaternário } \\
\text { Amónio }\end{array}$ & $\begin{array}{l}\text { Cl dialquil dimetil- } \\
\text { benzil amónio (50\%) } \\
\text { Perfume } \\
\text { Não lônico } \\
\text { Seqüestrante } \\
\text { Corante } \\
\text { Água q.S.p. }\end{array}$ & 1,70 & $\begin{array}{l}\text { Desinfeccāo: aplicar puro e deixar } \\
\text { agir por } 10 \text { minutos. } \\
\text { Limpeza: diluir } 2 \text { colheres de sopa } \\
\text { em } 1 \text { litro de água. Aplicar em } \\
\text { cozinhas, ralos, banheiros, vasos } \\
\text { sanitários. }\end{array}$ \\
\hline $3 \mathrm{C}$ & $\begin{array}{l}\text { Quaternário } \\
\text { Amônio }\end{array}$ & $\begin{array}{l}\text { Cl dialquil dimetil- } \\
\text { benzil amônio }(50 \%) \\
\text { Formaldeido } \\
\text { Näo lônico } \\
\text { Sequestrante } \\
\text { Corante } \\
\text { Perfume } \\
\text { Água q.s.p. }\end{array}$ & & $\begin{array}{l}\text { Desinfeccão: aplicar puro em } \\
\text { vasos sanitários, ralos, pias e latas } \\
\text { de lixo. Deixar agir por } 10 \text { minutos. } \\
\text { Limpeza: diluir } 100 \mathrm{~mL} \text { em } 1 \text { litro } \\
\text { de água e aplicar em pisos, pias, } \\
\text { azulejos, vidraças, etc. }\end{array}$ \\
\hline $3 D$ & $\begin{array}{l}\text { Quaternário } \\
\text { Amónio }\end{array}$ & $\begin{array}{l}\text { Cl dialquil dimetil- } \\
\text { benzil amônio }(50 \%) \\
\text { Formaldeído } \\
\text { Não lônico } \\
\text { Seqüestrante } \\
\text { Opacificante } \\
\text { Perfume } \\
\text { Água q.S.p. }\end{array}$ & & $\begin{array}{l}\text { Desinfecção: aplicar puro em } \\
\text { vasos sanitários, ralos, pias e latas } \\
\text { de lixo. Deixar agir por } 10 \text { minutos. } \\
\text { Limpeza: diluir } 100 \mathrm{~mL} \text { em } 1 \text { litro } \\
\text { de água e aplicar em pisos, pias. } \\
\text { azulejos, vidraças, etc. }\end{array}$ \\
\hline$\overline{3 E}$ & $\begin{array}{l}\text { Quaternário } \\
\text { Amônio }\end{array}$ & $\begin{array}{l}\text { Cl dialquil dimetil- } \\
\text { benzil amônio }(50 \%) \\
\text { Formaldeido } \\
\text { Perfume } \\
\text { Não lônico } \\
\text { Acidulante } \\
\text { Corante } \\
\text { Água q.s.p. }\end{array}$ & 1,00 & $\begin{array}{l}\text { Desinfeccáo: aplicar puro em } \\
\text { vasos sanitários, ralos e latas } \\
\text { de lixo. Deixar agir por } 10 \\
\text { minutos. } \\
\text { Limpeza: diluir } 50 \mathrm{~mL} \text { em } 1 \text { litro de } \\
\text { água e aplicar em pisos, pias, } \\
\text { azulejos e superfícies laváveis. }\end{array}$ \\
\hline $3 F$ & $\begin{array}{l}\text { Quaternário } \\
\text { Amônio }\end{array}$ & $\begin{array}{l}\text { Cl dialquil dimetil- } \\
\text { benzil amônio } \\
\text { Perfume } \\
\text { Näo lônico } \\
\text { Corante } \\
\text { Opacificante } \\
\text { Preservante } \\
\text { Água q.S.p. }\end{array}$ & 0,25 & $\begin{array}{l}\text { Desinfecção: aplicar puro e deixar } \\
\text { agir por } 10 \text { minutos. } \\
\text { Limpeza geral: diluir duas colheres } \\
\text { de sopa do produto em um litro de } \\
\text { água e aplicar. }\end{array}$ \\
\hline
\end{tabular}


Tabela 2 - Principais dados e informações declarados nos rótulos dos produtos, continuação:

\begin{tabular}{|c|c|c|c|c|}
\hline $\begin{array}{l}\text { Código } \\
\text { do } \\
\text { produto }\end{array}$ & $\begin{array}{l}\text { Principio } \\
\text { ativo }\end{array}$ & Composição & $\begin{array}{c}\text { Conc. } \\
(\%)\end{array}$ & Instruções de Uso \\
\hline $3 G$ & $\begin{array}{l}\text { Quaternário } \\
\text { Amônio }\end{array}$ & $\begin{array}{l}\text { Cl dialquil dimetil- } \\
\text { benzil amónio } \\
\text { Perfume } \\
\text { Não lônico } \\
\text { Preservante } \\
\text { Água q.s.p. }\end{array}$ & 0,25 & $\begin{array}{l}\text { Desinfeccão: aplicar puro e deixar } \\
\text { agir por } 10 \text { minutos. } \\
\text { Limpeza geral: diluir duas tampas } \\
\text { do produto em um litro de água e } \\
\text { aplicar. }\end{array}$ \\
\hline $3 H$ & $\begin{array}{l}\text { Quaternário } \\
\text { Amónio }\end{array}$ & $\begin{array}{l}\text { Cl dialquil dimetil- } \\
\text { benzil amónio } \\
\text { Perfume } \\
\text { Não lônico } \\
\text { Corante } \\
\text { Preservante } \\
\text { Água q.S.p. }\end{array}$ & 0,25 & $\begin{array}{l}\text { Desinfeccāa: aplicar puro e deixar } \\
\text { agir por } 10 \text { minutos. } \\
\text { Limpeza geral: diluir duas tampas } \\
\text { do produto em um litro de água e } \\
\text { aplicar. }\end{array}$ \\
\hline 31 & $\begin{array}{l}\text { Quaternário } \\
\text { Amônio }\end{array}$ & $\begin{array}{l}\text { Cl dialquil dimetil- } \\
\text { benzil amônio }(50 \%) \\
\text { Formaldeído } \\
\text { Não lônico } \\
\text { Perfume } \\
\text { Acidulante } \\
\text { Opacificante } \\
\text { Água q.s.p. }\end{array}$ & 0,88 & $\begin{array}{l}\text { Desinfeccão: aplicar puro em } \\
\text { vasos sanitários, ralos, pisos e } \\
\text { azulejos. Deixar agir por } 10 \\
\text { minutos. } \\
\text { Limpeza de ambientes: aplicar } \\
\text { puro com pano ou esponja e } \\
\text { deixar secar. }\end{array}$ \\
\hline
\end{tabular}

Nota - Cl: Abreviatura para "Cloreto de"; q.s.p: quantidade suficiente para $100 \%$ (p/p).

Através da análise das principais informações extraídas dos rótulos, constatou-se que a composição química é declarada pelos fabricantes de forma incompleta e insuficiente para se identificar, tanto qualitativa quanto quantitativamente, quais são os compostos orgânicos de ação antimicrobiana utilizados visando avaliar os produtos quanto à emissão de compostos tóxicos.

A maioria dos fabricantes não declara o nome quimico do conservante utilizado. Os componentes de fórmula são declarados por função (ex.: preservante) ou classe química (ex.: tensoativo não-iônico) e não de forma aberta, através do nome químico. 
A partir da análise dos dizeres de rotulagem, constatou-se que os desinfetantes de uso geral devem ser utilizados sem diluição. Isto se aplica à grande maioria dos produtos desinfetantes bactericidas comercializados até meados de 2002, pois o método de análise da eficácia microbiológica exigido pelo Ministério da Saúde requer a aplicação do produto na concentração de uso. Como os tipos de fórmula mais competitivas até então empregadas pelo fabricante só atuam a $100 \%$, a instrução de uso fornecida é para aplicar o produto puro sobre a superfície a ser desinfetada.

Os sistemas bactericidas encontrados foram agrupados em três tipos, a saber:

Tabela 3 - Sistemas bactericidas declarados nos rótulos dos produtos.

\begin{tabular}{lll}
\hline Sistema bactericida & \multicolumn{2}{l}{$N^{2}$ de produtos } \\
\hline Quaternário & 14 & $(82 \%)$ \\
Fenólico & 2 & $(12 \%)$ \\
Fórmico & 1 & $(6 \%)$ \\
\hline Total & 17 & $(100 \%)$ \\
\hline
\end{tabular}

O formaldeido é declarado como princípio ativo no rótulo de apenas um dos produtos, no qual o composto exerce a função de princípio ativo bactericida, por ser obrigatório por lei (a mesma obrigatoriedade nāo se aplica a conservantes). Entretanto é declarado apenas qualitativamente.

A composição química dos sistemas bactericidas declarados nos rótulos está descrita na tabela 4 a seguir. 
Tabela 4- Composição química dos sistemas bactericidas declarados nos rótulos dos desinfetantes de uso geral e suas respectivas concentrações*

\begin{tabular}{lll}
\hline $\begin{array}{l}\text { Tipo de } \\
\text { sistema }\end{array}$ & $\begin{array}{l}\text { Descrição quimica } \\
\text { dos principio ativos }\end{array}$ & $\begin{array}{c}\text { Concentração } \\
\% \mathrm{p} / \mathrm{p}\end{array}$ \\
bactericida & & 0,25 a 1,0 \\
Quaternário & Cloreto de dialquildimetilbenzilamônio \\
& $\begin{array}{l}\text { Associação de cloreto de dialquildi- } \\
\text { metilbenzilamônio com cloreto de } \\
\text { dialquildimetilamônio }\end{array}$ & 0,5 \\
Fenólico & Orto-benzil para-clorofenol & 0,25 a 1,00 \\
& Orto-feniffenol & 0,50 \\
\hline
\end{tabular}

$(*)$ Concentração expressa em porcentagem de peso por peso de produto $(\% p / p)$.

Estas informações referem-se ao "componente ativo", que é declarado no texto de rotulagem após a composição química. Embora seja uma obrigatoriedade legal (Portaria MS № 15/1988), o produto $1 C$, não declara a concentração de formaldeído utilizada.

\subsubsection{Determinações de formaldeído nos produtos}

A fim de confirmar a concentração de formaldeído nos desinfetantes, foi efetuada a análise por via úmida para todos os produtos. Os resultados encontram-se na tabela 5 a seguir. 
Tabela 5- Concentração de formaldeído analisada nos desinfetantes de uso geral encontrados no grande varejo da RMSP

\begin{tabular}{ccccc}
\hline $\begin{array}{c}\text { Código do } \\
\text { produto }\end{array}$ & $\begin{array}{c}\text { Concentração de } \\
\text { formaldeido }(\% \mathrm{p} / \mathrm{p})\end{array}$ & & $\begin{array}{c}\text { Código do } \\
\text { produto }\end{array}$ & $\begin{array}{c}\text { Concentração de } \\
\text { Formaldeido }(\% \mathrm{p} / \mathrm{p})\end{array}$ \\
\cline { 4 - 5 } $1 \mathrm{~A}$ & 0,8 & & $3 \mathrm{~A}$ & 0,7 \\
$1 \mathrm{~B}$ & 0,9 & $3 \mathrm{~B}$ & 0,2 \\
$1 \mathrm{C}$ & 7,5 & $3 \mathrm{C}$ & 0,2 \\
$2 \mathrm{~A}$ & 0.6 & $3 \mathrm{D}$ & 0,1 \\
$2 \mathrm{~B}$ & 0,2 & $3 \mathrm{E}$ & 1,8 \\
$2 \mathrm{C}$ & 0,7 & $3 \mathrm{~F}$ & 2,0 \\
$2 \mathrm{D}$ & 0,3 & $3 \mathrm{G}$ & 1,8 \\
$2 \mathrm{E}$ & 0,7 & $3 \mathrm{H}$ & 2,0 \\
& & 31 & 2,2 \\
\hline
\end{tabular}

De acordo estes resultados, foram selecionados 3 produtos (1A, 1B, 1C) para a realização das avaliações ambientais de formaldeido que iriam fornecer a base para a continuação da pesquisa, sendo os dois primeiros, fenólicos e o terceiro, aldeídico, tendo formaldeído como princípio ativo.

Foi detectada a presença de formaldeído nas 5 amostras da segunda coleta (produtos 2A, 2B, 2C, 2D, 2E), embora em concentraçōes inferiores às encontradas na etapa 1. Desses, foram selecionados mais dois produtos para a avaliação ambiental: $2 \mathrm{~A}$ e $2 \mathrm{~B}$. A finalidade foi avaliar os produtos em relação ao NOEL e ao limite ocupacional da ACGIH.

Somente quatro dos produtos (2B, 3B, 3C e 3D) apresentam concentração de formaldeído igual ou menor a $0,2 \%$. Concentrações elevadas, entre $0,9 \%$ e $7,5 \%$ de formaldeido foram detectadas em seis dos produtos (1C, $3 E, 3 F$, $3 \mathrm{G}, 3 \mathrm{H}, 3 \mathrm{I}$ ) indicando que o formaldeido é o composto que exerce a função de princípio ativo ou está sendo utilizado para potencializar a ação do 
princípio ativo efetivamente declarado. Nestes casos, o formaldeido deveria ser declarado no rótulo, qualitativa e quantitativamente conforme exigência da Portaria № 15/1988.

Houve um caso em que a concentração praticada foi o dobro da declarada (produto 1A). Esta parece ser uma das formas dos fabricantes reduzirem o custo do produto, pois o formaldeído tem alta eficácia antimicrobiana e seu preço é o mais baixo entre as matérias-primas de ação antimicrobiana empregadas em desinfetantes de uso geral.

Uma terceira etapa de coleta de mercado foi efetuada para se completar o trabalho abrangendo todos os produtos desinfetantes de uso geral inclusive marcas recém lançadas nos supermercados amostrados. Os produtos foram os seguintes: 3A. 3B, 3C, 3D, 3E, 3F, 3G, 3I. Efetuou-se as determinações de formaldeído constatando-se novamente que todos os produtos continham formaldeído.

Os produtos $3 \mathrm{~F}, 3 \mathrm{G}, 3 \mathrm{H}$ e 31 apresentaram concentrações mais elevadas de formaldeído, entre 1,8 e 2,0\%. Como estas concentrações estão acima de $0,9 \%$, que foi determinada na primeira etapa como a concentração que produziu uma concentração no ar superior aos limites de tolerância ocupacional (LEO) brasileiro e estrangeiros, julgou-se desnecessário prosseguir com as avaliações ambientais destes outros produtos.

Buscando-se uma possível explicação para o uso disseminado do formaldeído nos desinfetantes além da sua eficácia antimicrobiana, foi feita uma pesquisa de preço envolvendo três fabricantes. Apurou-se que o preço do formaldeído está por volta de US $\$ 0,50 / \mathrm{kg}$, com variações em função do volume do pedido de compra. Já o preço do cloreto de alquildimetilbenzilamônio, por exemplo, variou entre US\$ 1,80 a $3,00 / \mathrm{Kg}$.

\subsubsection{Avaliações ambientais de formaldeído}

As avaliações foram realizadas à temperatura ambiente $\left(25^{\circ} \mathrm{C}\right.$ na etapa $1 \mathrm{e}$ $25,3^{\circ} \mathrm{C}$ na etapa 2) e umidade relativa do ar de $70 \%$. Os resultados obtidos 
para a concentração de formaldeído no ar foram corrigidos para $25^{\circ} \mathrm{C}$ e 760 $\mathrm{mmHg}$ e estão apresentados nas tabelas 6 e 7 a seguir. $O$ indice de exposição (IE) representa a razão entre 0 resultado obtido (C) e 0 correspondente limite de exposição (L):

$$
I E=\frac{C}{L}
$$

Se IE for superior a 1, considera-se que há exposição excessiva acima do limite. Neste caso, foi adotado o limite da ACGIH.

Tabela 6 - Concentração total de formaldeído no ar, emitido na desinfecção dos sanitários - Etapa 1

\begin{tabular}{|c|c|c|c|c|}
\hline Produto & $\begin{array}{l}\text { Sanitário } \\
\text { (código) }\end{array}$ & Periodo & $\begin{array}{l}\text { Concentração de } \\
\text { formaldeido no ar } \\
\text { (mg/m3) }\end{array}$ & $\begin{array}{l}\text { Indice de } \\
\text { exposição }\end{array}$ \\
\hline $1 \mathrm{~A}$ & DTF & $9: 30-17: 00 h$ & 2,0 & 5,4 \\
\hline 1B & EDM & $11: 10-17: 10 \mathrm{~h}$ & 3,4 & 9,19 \\
\hline $1 \mathrm{C}$ & ETF & $11: 35-17: 00 h$ & $>49$ & $>132$ \\
\hline
\end{tabular}

(Data do teste: 04/01/02)

Observaçōes:

a) $\mathrm{O}$ produto $1 \mathrm{~A}$ apresentou odor de pinho bastante intenso. 
b) $\mathrm{O}$ produto $1 \mathrm{C}$ provocou intensa irritação nos olhos, garganta e nariz a ponto da operadora e pesquisadora ficarem sufocadas, sendo que a operação de aplicação do desinfetante passou a ser efetuada usando-se máscara contra gases com filtro de carvão ativado após os 3 primeiros minutos. O odor de formaldeído permaneceu no ambiente por cerca de 5 horas.

c) Posteriormente, quando contatado pela pesquisadora, o funcionário do serviço de atendimento ao cliente do fabricante do produto $1 \mathrm{C}$ informou que é comum ocorrer forte ardência nos olhos, nariz e garganta e que, no seu entender, este produto não é indicado para uso puro em ambientes fechados como sanitários, que normalmente têm pouca ventilação, embora não haja qualquer advertência no rótulo, que conta com a aprovação do Ministério da Saúde. $O$ produto pode ser usado diluído, porém neste caso, apresenta apenas ação desodorizante.

O produto contendo $7,5 \%$ de formaldeído, resultou em concentração no ar superior a $49 \mathrm{mg} / \mathrm{m}^{3}$ no ar a $25^{\circ} \mathrm{C}, 760 \mathrm{mmHg}$ (média de $5,5 \mathrm{~h}$ ), o que aponta para a necessidade de uma ação imediata em relação à comercialização desse produto, pois é impossivel aplicá-lo puro, como desinfetante, seguindo as instruções do rótulo. A concentração no ar durante os 15 minutos iniciais para o produto contendo $0,6 \%$ foi $0,47 \mathrm{mg} / \mathrm{m}^{3}$. Estes niveis de exposição estão acima do limite de exposição médio de $0,37 \mathrm{mg} / \mathrm{m}^{3}$ da American Conference of Governmental Industrial Hygienists (ACGIH/EUA) e do limite de efeito não observável (NOEL) de $0,25 \mathrm{mg} / \mathrm{m}^{3}$ da Intemational Agency for Research on Cancer (IARC).

Comparando estes resultados com o critério ocupacional brasileiro de limite de tolerância $\left(2,3 \mathrm{mg} / \mathrm{m}^{3}\right)$, o produto $1 \mathrm{~A}$ com $0,8 \%$ de formaldeído está aprovado. Porém, a $0,9 \%$ (produto 1B), a exposição ao desinfetante já oferece risco à saúde. Isto é confirmado também pela comparação com o NOEL $\left(2,5 \mathrm{mg} / \mathrm{m}^{3}\right)$. 
Para a segunda etapa da avaliação ambiental, escolheu-se mais dois produtos de concentração mais baixa de formaldeído em relação aos avaliados na etapa 1: produtos $2 \mathrm{~A}$ e $2 \mathrm{~B}$, ambos de formulação quaternária.

Na etapa 2, a fim de enriquecer o estudo com maiores informações sobre a curva de concentração de formaldeído emitido pelos produtos ao longo do tempo, o sistema de amostragem foi alterado para se avaliar a exposição durante a aplicação e após a aplicação. Durante a aplicação, foi feita a amostragem pessoal com a bomba fixada na altura da zona respiratória. Em seguida, procedeu-se à coleta em ponto fixo na zona respiratória instalandose a bomba no centro do sanitário até o final da amostragem, representando a situação de alguém que permanecesse no local durante todo o tempo restante. Os resultados obtidos estão descritos na tabela 7 a seguir.

Tabela 7 - Concentração de formaldeído no ar, emitido durante e após a desinfecção dos sanitários - Etapa 2

\begin{tabular}{|c|c|c|c|c|}
\hline $\begin{array}{l}\text { Pro- } \\
\text { duto }\end{array}$ & $\begin{array}{l}\text { Sani- } \\
\text { tário }\end{array}$ & $\begin{array}{c}\text { Período } \\
\text { de Avaliação }\end{array}$ & $\begin{array}{c}\text { Concentração de } \\
\text { formaldeido no ar } \\
\left(\mathrm{mg} / \mathrm{m}^{3}\right)\end{array}$ & $\begin{array}{l}\text { Índice de } \\
\text { exposição }\end{array}$ \\
\hline \multirow[t]{2}{*}{$2 A$} & DTF & Durante a aplicação (15 min.) & 0,47 & 1,27 \\
\hline & & Após a aplicação (5h e 55 min.) & 0,09 & 0,24 \\
\hline \multirow[t]{2}{*}{$2 B$} & DTM & Durante a aplicação (15 min.) & 0,14 & 0,38 \\
\hline & & Após a aplicação (5h e 55 min.) & 0,043 & 0,12 \\
\hline
\end{tabular}

(Data do teste: 05/03/02)

Pelo critério da ACGIHIUSA $\left(0,37 \mathrm{mg} / \mathrm{m}^{3}\right)$ e MAK I Alemanha $\left(0,6 \mathrm{mg} / \mathrm{m}^{3}\right)$, os niveis de exposição são todos elevados e todos os produtos foram reprovados, exceto o produto $2 \mathrm{~B}$ contendo $0,2 \%$ de formaldeído, que foi aprovado segundo os critérios ocupacionais e segundo o NOEL, entretanto o nivel de exposição está acima do recomendado pelo CPSC/USEPA $(0,1$ ppm). 
Os resultados dos produtos $1 \mathrm{~B}$ e $1 \mathrm{C}$ são muito significativos pois $1 \mathrm{~B}$ é líder de mercado e $1 \mathrm{C}$ é mais utilizado justamente em situações em que há pessoas doentes em casa (portanto mais susceptiveis a problemas respiratórios causados por $\mathrm{COVs}$ ). $\mathrm{O}$ produto $1 \mathrm{C}$ gerou uma exposição elevadíssima e incompatível com todos os parâmetros toxicológicos considerados.

Através da avaliação ambiental de formaldeído durante a desinfecção dos sanitários, confirmou-se que 0 formaldeído presente nos produtos pesquisados é emitido e os níveis de exposição alcançados representam risco à saúde, pois a concentração no produto resulta em concentrações no ar interior, principalmente durante a sua aplicação, superiores ao NOEL, aos limites de tolerância ocupacional, estando também acima dos limites a partir dos quais, o indivíduo pode ter sinais de desconforto e sintomas de irritação. Este risco atinge todos os ocupantes do ambiente, porém em maior proporção, o indivíduo que aplica o produto, momento em que a concentração de formaldeido no ar é maior, conforme comprovado através das avaliações ambientais.

Analisando-se os resultados da etapa 2, ou seja, na qual foi feita a amostragem durante e após a aplicação, verifica-se que a exposição ao formaldeído é mais crítica durante os primeiros 15 minutos, quando há a aplicação do produto, do que no tempo restante.

Diante das inúmeras dificuldades em conduzir a parte experimental desse estudo, tendo contatado os mais de dez laboratórios mencionados e realizado testes-piloto em três deles, foi possivel verificar que a capacitação técnica e humana da estrutura laboratorial do Brasil é deficiente nos recursos necessários para se desenvolver estudos ligados à Ciência do Ambiente Interior, notadamente na área de Química Analítica. De fato, numa avaliação preliminar conduzida pela Gerência Geral de Saneantes da ANVISA (BICHO e PICH 2001) sobre a capacitação dos laboratórios prestadores de serviço no que se refere aos ensaios exigidos para o registro de produtos saneantes, concluiu-se que nenhum dos laboratórios do país 
está apto a atender a $100 \%$ das exigências analíticas legais atuais para fazer parte da Rede Brasileira de Laboratórios (REBLAS).

\subsection{Análise de aspectos da legislação sanitária}

A legislação acerca do controle da Qualidade do Ar Interior encontra-se dispersa, demandando integração das áreas de interface que envolvem a Saúde Pública, Saúde Ambiental e Saúde Ocupacional, a fim de ganhar coerência, o que é indispensável para a eficácia dos seus dispositivos, que apresentam as normas de regulamentação, os padrōes referenciais e as recomendações técnicas.

$\mathrm{Na}$ busca de parâmetros para gerenciamento do risco, os limites ocupacionais, embora não possam ser utilizados sem as devidas ponderações, acabam servindo de orientação para a tomada de decisões ético-legais para substâncias reconhecidas como potencialmente perigosas como as listadas no Grupo $2 A$ do $I A R C$, enquanto novos estudos não trouxerem $\circ$ tratamento adequado para a realidade dos ambientes interiores.

Durante a realização dessa pesquisa foi publicada a Resolução MS №176 de 2000, que foi incluida na análise, tendo sido extraídos os principais elementos relativos a compostos orgânicos voláteis.

Especificamente com relação aos COVs, a legislação brasileira ainda não contempla padrões, mas apenas algumas recomendações para fins de pesquisa, avaliação e correção das situações encontradas, incluindo especificamente 0 formaldeido contido em produtos saneantes domissanitários. Embora estas recomendações se apliquem a ambientes climatizados artificialmente de uso público e coletivo, é sensato considerar que, para o ocupante preocupado com sua saúde e não apenas com aspectos legais, estas recomendações bem como os parâmetros sugeridos de consensos internacionais sobre os riscos à saúde ambiental e humana, já deveriam estar sendo amplamente 
divulgadas e seguidas pela Sociedade Civil, também para ambientes residenciais, uma vez feitas as considerações em relação à duração e freqüência da exposição.

Nenhum dos desinfetantes de uso geral adquiridos na RMSP está em conformidade com as recomendações da Resolução № 176 de 24 de outubro de 2000 e não poderia ser usado em interiores, pois contêm formaldeído, e, portanto, se constituem em fonte de poluição química. Não se observa, portanto, comprometimento dos principais agentes desse processo, com os impactos do uso do produto final na qualidade do ambiente interior e na qualidade de vida dos seus ocupantes, salvo algumas empresas comprometidas com saúde, segurança e meio ambiente.

Embora a execução das ações de vigilância sanitária e o estabelecimento de normas relativas a ambos os assuntos sejam atribuições da mesma agência, a ANVISA, as portarias e resoluções publicadas apresentam incompatibilidade.

Confrontando-se a legislação pertinente à regulamentação de saneantes domissanitários e ao controle da QAI, identificou-se um ponto de incoerência. A Portaria MS № 15 de Agosto de 1988 do Ministério da Saúde autoriza o uso do formaldeído como princípio ativo em produtos para uso doméstico, em locais públicos e indústrias, sem restrições ou limites de concentração e não exige apresentação da taxa de volatilidade do produto no relatório técnico de registro. Por outro lado, a Resolução № 176 de 24 de Outubro de 2000 , que regulamenta a Portaria 3.523 de 28 de agosto de 1998 do Ministério da Saúde a qual obriga a manutenção e limpeza de sistemas de ar condicionado, traz recomendações sobre o controle de fontes de poluição química do ar interior no sentido de "usar produtos domissanitários que não contenham formaldeído" ou outro composto orgânico volátil ou ainda "que não apresentem alta taxa de volatilização e toxicidade".

Verificou-se portanto, que o formaldeído está permitido como agente de ação antimicrobiana na Portaria № $15 / 1988$ sem qualquer restrição de 
concentração e, por outro lado, não é recomendado pela Resolução 176/2000 para produtos saneantes domissanitários.

\subsection{Iniciativas relacionadas à Prevenção da Poluição Química do Ar Interior e a produtos de limpeza}

De acordo com a pesquisa realizada, alguns estados, órgãos públicos e cidades dos Estados Unidos da América criaram a chamada matriz de atributos ambientais para seleção e compra de produtos, alguns dos quais referem-se a padrões de volatilidade e limites de COVs. Exemplos de práticas dessa natureza de contrato de compra podem ser conferidos no Estado de Massachusetts (COMMONWEALTH OF MASSACHUSETTS 2001), na cidade de Santa Mônica, Seatle etc.

A lista de especificações de produto desses contratos no que concerne aos chamados produtos ambientalmente preferiveis ou green cleaning products, inclui especificações de caráter obrigatório ou desejável, como no caso de Massachusetts. A vantagem dessa prática de comercialização de produtos para os fabricantes é a economia com a eliminação de responsabilidades e processos legais.

Organizações independentes de rotulagem ambiental fazem a certificação de produtos de uso doméstico, industrial e institucional com base em rigorosos testes para a verificação de padrões de referência envolvendo também o controle de COVs. Este é caso do Green Seal, que com base nas Listas Nacionais de produtos existentes, em parâmetros toxicológicos e ecotoxicológicos, em critérios de performance, aspectos de embalagem e rotulagem, certifica a qualidade dos produtos. No que se refere diretamente ao controle de COVs em produtos de uso doméstico, existem os seguintes padrōes (GREEN SEAL 2001):

- o produto não deve conter COVs em concentração superior a $10 \%$ do peso do produto, medido pelo Método 24 ou 24A, 40 CFR Parte 60, 
Anexo A; Método 18, 40 CFR Parte 60, anexo A ou Método 8240 ou conforme demonstrado pelo fabricante com base nos dados da fórmula;

- o produto, conforme utilizado, não pode conter substâncias que contribuam significativamente para a produção de smog fotoquímico, ozone troposférico ou a Qualidade do Ar Interior ruim.

- o conteúdo orgânico volátil do produto conforme utilizado, não deve exceder $1 \%$ do peso para limpadores de uso geral e de banheiros, e $3 \%$ do peso para limpa-vidros.

Estes padrões se aplicam a produtos de uso doméstico, institucional e industrial, nacionais ou importados, indistintamente.

Cabe destacar aqui que 0 escritório de planejamento e normas da Qualidade do Ar da USEPA estabeleceu a regulamentação de produtos em spray para cabelos, tintas e outros produtos de consumo através da Clean Air Act, em 1990. Os parâmetros referenciais são estabelecidos pela USEPA através do National Volatile Organic Compound Emission Standards for Consumer Products. Por exemplo, o limite para o conteúdo de COV para limpadores de banheiro, azulejos e outras superfícies em banheiros é de $5 \%$ e para limpadores de uso geral é de 10\% (EPA 1998).

Nos países onde 0 formaldeído tem sido substituído por conservantes alternativos, é a pressão pública, mais do que as açōes da Vigilância Sanitária, que cataliza as substituições do formaldeído das diversas categorias de produto, principalmente os cosméticos. 


\section{CONCLUSÃO}

Diante dos resultados e da discussão efetuada neste estudo, conclui-se que existem desinfetantes de uso geral, comercializados na RMSP, que se constituem em fontes de poluição química do ar interior, pois podem emitir formaldeido, um composto orgânico altamente volátil, extremamente irritante e classificado como potencial carcinógeno para humanos pela IARC.

Verificou-se, através de experimentos, casos de produtos que resultaram em elevados niveis de exposição para $\circ$ indivíduo envolvido ocupacionalmente na atividade de desinfeç̧ão de sanitários. Para o cidadão-consumidor, embora seja menor a freqüência de exposição, também existe risco à saúde, principalmente para os individuos mais susceptiveis ou alérgicos.

Ficou evidenciada, a partir desse estudo, a existência de incompatibilidade na legislação sanitária brasileira, havendo necessidade de revisão da norma pertinente à regulamentação de produtos saneantes domissanitários de ação antimicrobiana (Portaria MS № 15/1988), a qual permite o uso de formaldeido em desinfetantes de uso geral doméstico e profissional sem qualquer restrição de concentração, enquanto a Resolução MS № 176/2000, recomenda não usar os produtos que contenham formaldeído em ambientes de uso público e coletivo.

Existem alternativas de formulação de produto e outros princípios ativos de ação antimicrobiana mais seguros e economicamente viáveis em relação ao formaldeído, utilizado como desinfetante ou como conservante, porém a sua substituição requer mudanças de âmbito político e técnico na Vigilância Sanitária, especificamente relacionadas à gestão da QAl, que visem a efetiva proteção da Saúde Pública, em caráter preventivo. 


\subsection{Recomendações}

1. Com base no conhecimento disponível do efeito carcinógeno do formaldeído, comprovado em animais e suspeito em humanos, e nos resultados das avaliações ambientais efetuadas, entende-se que o uso deste composto deve ser proibido em produtos de limpeza. Recomendase uma ação imediata em relação ao produto $1 \mathrm{C}$, no qual o formaldeído é o princípio ativo, descontinuando a sua comercialização, uma vez que é impossivel usá-lo como desinfetante embora o rótulo não o declare, contrariando assim a disposição da Portaria № 15/1988.

2. Recomenda-se que sejam incluidos na Portaria № 15/1988, aspectos ligados à volatilidade para fins de registro de fórmula, como por exemplo, limite de \% COVT p/p por categoria de produto de limpeza e/ou pressão de saturação de vapor. Poderia ser avaliada a adoção de padrōes de emissão de COVs em produtos de consumo (\% COVT p/p) como os estabelecidos pelo Code of Federal Register dos Estados unidos, que recomenda, por exemplo, o máximo de 5\% (Environmental Protection Agency, 1998) para limpadores de banheiro e azulejos.

3. Além das observações apontadas acima, a regulamentação de uso de novas substâncias de ação antimicrobiana poderia ser modificada, exigindo-se para a aprovação de nova substância, que cada empresa fornecedora solicite o registro da substância ao referido Orgão, apresentando, para isso, o relatório técnico completo segundo a finalidade de uso pleiteada. Este relatório técnico seria o mesmo exigido atualmente pela Portaria № $15 / 88$, incluindo dados toxicológicos e comprovação de eficácia. Entretanto, ao invés do novo ingrediente estar aberto à comercialização para todo o mercado, somente os fornecedores que realizam os estudos toxicológicos e ecotoxicológicos poderiam atuar no mercado de matérias-primas microbicidas. Da mesma forma, seria mantida a opção de aprovação automática da marca da empresa que apresentar o documento de aprovação no FDA, USEPA e outras 
agências internacionais, como é feito atualmente. Esta modificação poderia nortear a substituição do formaldeído por outras alternativas de forma mais efetiva, uma vez que é sabido que o perfil toxicológico de uma matéria-prima pode ser modificado dependendo do processo de fabricação, dos subprodutos gerados, do solvente associado à molécula biocida, e, principalmente do tipo de cadeia e distribuição carbônica da molécula, muito embora através da análise química convencional não se possa distinguir entre produtos de qualidade diferentes. Para evitar isso, são necessários grandes investimentos em tecnologia e qualidade de manufatura, condiçōes a que somente empresas sérias, formalmente instaladas no mercado, podem fazer jus. Esta preocupação deve ser maior para as matérias-primas de ação antimicrobiana (desinfetantes ou conservantes) do que para as demais, tais como detergentes e etc., devido à inerente toxicidade dos biocidas e à essencialidade dos produtos de ação antimicrobiana na proteção da saúde humana e ambiental. Além disso, esta mesma medida teria efeito no combate à informalidade na cadeia produtiva de produtos de limpeza.

4. Quanto ao cidadão-consumidor, a escolha correta do produto de limpeza poderia ser feita com base em selos de certificação de qualidade emitidos por organizaçōes independentes como as sociedades científicas ou de acordo com padrões e orientações técnicas estabelecidos em normas.

\subsection{Proposta de criação do projeto de Prevenção da Poluição do Ar Interior}

A seguir são apresentadas e comentadas algumas ações de curto, médio e longo prazo para a Prevenção da Poluição Química do Ar Interior visando a redução de risco à saúde humana, envolvendo:

1. Estado: Ministérios e secretarias estaduais e municipais responsáveis pela área de Saúde, Educação, Meio Ambiente, Ciência e Tecnologia ressaltando-se o papel de órgãos de apoio como CNPq, FINEP, CAPES 
e FAPESP, iniciativas de apoio à micro e pequenas indústrias como o SEBRAE e outros;

2. Instituições de Educação e Pesquisa: Universidades (núcleos de referência em conhecimento $e$ informação), grupos de estudo e pesquisa, fundações, laboratórios, escolas, sociedades científicas;

3. Empresas: fabricantes de produtos e fornecedores de especialidades químicas, associações de classe, laboratórios prestadores de serviço, setores da Comunicação.

4. Cidadão: consumidores, organizações não governamentais, associações.

Várias das ações propostas envolvem mais que um setor da Sociedade pois a interação entre eles é condição fundamental para a integração das políticas e Sistemas de Gestão Ambiental Interior.

De um modo concreto, propõe-se nesse estudo que seja criado um projeto de Prevenção da Poluição do Ar Interior (PPAl) de abrangência nacional, com planos voltados aos poluentes químicos, biológicos e físicos.

Tratando-se especificamente do plano voltado a COVs provenientes de produtos de limpeza, este poderia ficar sob a competência do Sistema Nacional de Vigilância Ambiental em Saúde (SINVAS), sob a coordenação da Vigilância de Fatores de Risco Não Biológicos, na área de Qualidade do Ar elou Contaminantes Ambientais, para a qual poderia se definir uma Lista Nacional de Produtos, entre os quais estariam os COVs potencialmente perigosos para o ser humano e o meio ambiente.

Dentro do modelo de financiamento existente para o SINVAS, que está baseado no orçamento da União, poderia ser acrescentado um fundo especifico para o PPQAl com a alocação de recursos provenientes das indústrias. Este fundo seria destinado ao fomento de linhas de pesquisa em Ciência \& Tecnologia, voltadas para climatização e higienização de interiores, bem como ao fomento de campanhas de comunicação visando a conscientização e reeducação sobre o uso de produtos de limpeza. Estas 
linhas de pesquisa poderiam ser desenvolvidas em esquema de cooperação com as Universidades, que se incumbiriam também da formação de recursos humanos na área de QAl, e com grupos internacionais que já desenvolvem projetos semelhantes, tal como o Janitorial products Pollution Prevention Project, projeto norte-americano subsidiado pela USEPA.

Para exemplificar, algumas necessidades identificadas durante este estudo, estão resumidamente descritas a seguir, as quais poderão servir de base para se delinear o projeto de PPAl.

- Criar uma base de dados para a realização de estudos mais avançados sobre a avaliação de produtos ambientalmente preferiveis para higienização de interiores visando dar suporte à tomada de decisões em QAI. Isto envolve parâmetros físico-químicos (pressão de vapor, ponto de ebulição, coeficiente de partição octanol-água), e limites sensoriais (odor e irritação das vias respiratórias), bem como solubilidade e reatividade.

- Fomentar estudos avançados que incluam modelos de extrapolação de conclusões com base em altas concentrações para baixas concentrações, o que corresponderia à extrapolação de conclusões sobre a fase líquida para a fase gasosa, na fonte e, posteriormente, no $a r$, em função da ventilação, da curva de decaimento do contaminante no ar e etc, correlacionando então estes fatores com os reais riscos à saúde. Estes estudos exigem sofisticada instrumentação em Química Analítica Orgânica para detectar partes por trilhão de moléculas no ar além de mão-de-obra altamente especializada, o que demanda tempo e elevado investimento.

- Capacitar a estrutura laboratorial do país para a realização de estudos semelhantes ao presente, envolvendo outros COVs, isolados ou em misturas, na categoria de produtos de ação antimicrobiana, outras categorias de produtos saneantes domissanitários, além de produtos de higiene pessoal e cosméticos. Esta capacitação refere-se a recursos técnicos como métodos analíticos mais precisos e acurados do que os 
existentes, instrumentação e padrões analíticos bem como recursos humanos, pois é necessário contar com mão-de-obra altamente especializada para realizar estudos avançados em QAI. Esforços devem ser dedicados também ao desenvolvimento de técnicas analíticas de menor custo para fins de gerenciamento de risco.

- Priorizar medidas de caráter preventivo que requerem o diagnóstico do problema da QAI para a realidade brasileira e a proposição de medidas de curto prazo, de natureza técnica e legal, simples, de baixo custo e que possam minimizar os efeitos dos compostos mais perigosos sobre a Saúde Humana.

- Implementar novos conceitos de formulação de produtos de limpeza com base num princípio básico de prevenção da poluição: evitar adicionar substâncias desnecessárias na fórmula e manter sua conformidade com as exigências e recomendações sanitárias estabelecidas nas políticas públicas de Saúde e Meio Ambiente, principalmente sem deixar de contemplar a manutenção ou melhoria do desempenho, centrada na eficácia antimicrobiana, segurança em uso e melhor relação custobenefício. Cabe aos profissionais de Marketing, em conjunto com os da área técnica, trabalhar para que as instruçōes de uso sejam claras, contemplem informação sobre diluição e possíveis inativantes do princípio ativo, tempo de contato, contribuindo assim para assegurar 0 uso correto do produto pelo consumidor.

- Produzir trabalhos voltados para o desenvolvimento de produtos de limpeza na comunidade científica do país, pois os trabalhos existentes, produzidos pelos fabricantes, se resumem, não raro, à adaptação de fórmulas de outros países. A Universidade está ainda mais distante deste núcleo de conhecimento, pois os formuladores são capacitados pela própria indústria, geralmente no próprio exercício da atividade e freqüentemente de forma empírica, o que tem levado certas práticas sem ter fundamento a se estabelecerem ao longo do tempo, comprometendo a qualidade do produto de forma geral, incluindo a QAI. 
- Reforçar o compromisso da área acadêmica, nas diferentes disciplinas pertinentes ao ambiente interior; estudos semelhantes a este devem ser estendidos a outros COVs, isolados ou em misturas, na categoria de produtos de ação antimicrobiana, outras categorias de produtos saneantes domissanitários, além de produtos de higiene pessoal e cosméticos. Médicos, arquitetos, químicos, engenheiros civis e administradores precisam ter o conteúdo de seus programas e cursos revistos, a fim de adequá-los à nova realidade. Os arquitetos devem voltar sua atenção para projetar e operar edifícios saudáveis prevenindo a Síndrome do Edifício Doente; ventilação e renovação do ar são itens que devem ser enfatizados nos projetos.

- Avaliar alternativas de substituição de formaldeído por outros conservantes em todas as categorias de produtos de limpeza.

- Discutir certificação ambiental de produtos, que seriam avaliados quanto à concentração percentual máxima de COVTs por peso de produto. Por exemplo, para desinfetantes de uso geral, poderia ser adotado o limite de $5 \%$ p/p. A Vigilância Sanitária verificaria o cumprimento dessa norma, simplesmente através do registro da fórmula declarada.

- Incentivar iniciativas de reeducação do consumidor através de agentes formadores de opinião da mídia, visando a mudança de hábitos para prevenir o mau uso de produtos de limpeza na rotina diária. Por exemplo, habituar-se a consultar informação a respeito dos produtos e materiais, bem como das interações entre contaminantes do ambiente lendo e obedecendo as instruções de rótulo e fichas de segurança fornecidas pelos fabricantes; manter a casa bem ventilada, remover fontes de emissão bem como substituir produtos de consumo e materiais de acabamento, etc. Ao invés das receitas de produto de limpeza feito em casa, as revistas, programas de televisão e páginas de internet divulgariam informação e conhecimento com $o$ apoio dos fabricantes e suas associações, em conjunto com o Ministério da Saúde e de forma contínua. Os resultados desse tipo de medida são colhidos a longo 
prazo, uma vez que a conscientização do consumidor depende de ações na Comunicação e na Educação, num âmbito mais amplo.

- Criar canais de comunicação do consumidor com a Vigilância Sanitária e Ambiental através de páginas de internet elou telefone para permitir que o consumidor exerça ações fiscalizadoras sobre os produtos de limpeza e possa contar com uma fonte de informação, uma vez que o Estado está mal estruturado e não tem conseguido atender às demandas da comunidade, em função da falta de funcionários no país todo, conforme freqüentemente alegado pelas autoridades do governo.

- Capacitar melhor os administradores de condomínios, as chamadas limpadoras de empresas e os trabalhadores do setor de limpeza, apoiando as iniciativas da ABRALIMP e SINDICON: Escola de Ensino Profissionalizante e o manual de processos de limpeza profissional "Gerenciamento de Higiene e Limpeza".

Encontra-se no anexo 1, ○ Roteiro de Formulação de Desinfetantes, elaborado juntamente com a presente pesquisa no intuito de contribuir com mais detalhes sobre a formulação de desinfetantes, tendo em vista que a maior parte do conhecimento nesta área é gerado pela indústria e, geralmente, a ela permanece restrito, sendo difícil encontrar boas referências bibliográficas de autores brasileiros sobre do tema. A diferença desse roteiro com a prática tradicional de formulação de produtos de limpeza, está na inserção dos princípios básicos de desenvolvimento de produtos de limpeza ambientalmente preferiveis, que foram elaborados a partir da combinação de elementos de conhecimento em Química e Meio Ambiente com a prática em desenvolvimento de produtos químicos de consumo.

Além da preocupação com a integração entre os setores da Sociedade que têm responsabilidades em relação à gestão da Qualidade do $\operatorname{Ar}$ de Interiores, salienta-se o comprometimento dos responsáveis pela concretização e, principalmente, pela continuidade das ações que forem 
concordadas, pois este é o mais importante fator de sucesso dos planos, programas e projetos da área de Saúde Pública.

\subsection{Análise das hipóteses}

A primeira hipótese, de que alguns produtos de limpeza atualmente disponiveis no mercado brasileiro apresentam risco à saúde humana foi comprovada neste estudo. Pesquisada a subcategoria de desinfetantes de uso geral encontrados na RMSP, comprovou-se que estes produtos constituem fontes de emissão de formaldeído, um Composto Orgânico Volátil e tóxico, que apresenta risco à Saúde.

Dependendo da taxa de renovação, temperatura e umidade do ar bem como dos niveis de exposição ao formaldeído atingidos na desinfecção de sanitários, os desinfetantes de limpeza contendo formaldeído apresentam risco de provocar desde problemas alérgicos até provavelmente até câncer, principalmente nas vias respiratórias superiores. Este risco é maior para o individuo que aplica o produto do que para os ocupantes em geral, seja em ambientes ocupacionais, residenciais bem como públicos e coletivos.

Referente à segunda hipótese, como solução técnico-legal, a avaliação de produtos de limpeza quanto à emissão de Compostos Orgânicos Voláteis poderia ser incluída na Política de Vigilância Sanitária do Brasil como instrumento de gestão da Qualidade do Ar Interior. A veracidade dessa hipótese ficou evidenciada quando se confrontou a legislação do Ministério da Saúde pertinente à regulamentação de produtos de limpeza de 1988 com as principais medidas de correção em ambientes interiores da Resolução № 176 de 2000, concluindo-se que é necessário adotar padrōes de volatilidade para produtos de limpeza na norma de registro de produto no Ministério da Saúde.

A avaliação de volatilidade, por COV ou COVs totais passaria a ser um instrumento de gestão da Qualidade do Ar Interior para quem desenvolve novos produtos ou aprova o uso de produtos em interiores, por exemplo: 
administradores de condomínios de escritório ou hospitais, órgãos certificadores de produtos de limpeza e outras categorias de produto de consumo, etc.

Assim, a comprovação das hipóteses formuladas neste estudo apresenta progressos para o conhecimento e gestão da qualidade do ar interior, os quais poderão levar a melhorias na Saúde Ambiental, à medida que as recomendaçōes dadas sejam colocadas em prática.

\subsection{Perspectivas}

A elaboração dessa pesquisa tornou ainda mais evidente a relevância de se buscar avanços no estudo da QAI. Embora pela primeira vez tenha sido realizada uma pesquisa desta natureza para uma categoria de produto de limpeza, através do método adotado, as conclusões desse estudo permitiram antever a necessidade de dar-lhe continuidade. Poderiam ser avaliadas outras categorias de produto, por exemplo, cosméticos, e outros COVs, especialmente os perfumes e solventes.

Foi possivel ainda identificar desafios de conhecimento e complexidades na Prevenção da Poluição Química do Ar Interior e vislumbrar muitas oportunidades de melhoria da Saúde através de novos instrumentos de Gestão Ambiental e de ações alternativas com a participação da comunidade organizada, as quais podem facilitar e assegurar o caminho em direção ao desenvolvimento e uso correto de produtos de limpeza que não comprometam a QAI. 


\section{REFERÊNCIAS}

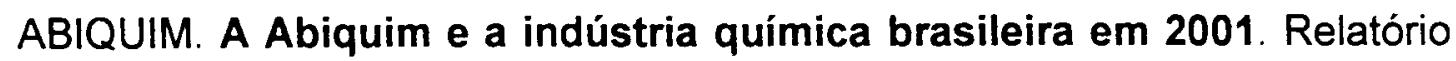
Annual 2001. ABIQUIM, Abril de 2002.

ABRALIMP. Gerenciamento de higiene e limpeza em ambientes internos e externos: Manual de Processos. 1a. ed. São Paulo: 1999.

[ACGIH]. American Conference of Governmental Industrial Hygienists. Industrial Ventilation (1995). Ventilation aspects of indoor air quality industrial ventilation - a manual of recommended practice. Ohio: $22^{\text {nd }}$; 1995 ed. Secção 8.

[ATSDR]. Agency for Toxic Substances and Diseases Registry. Public health statement for formaldehyde. July, 1999. Available from URL: http://www.atsdr.cdc.gov/toxprofiles/phs111.html (11 May, 2002).

Alexandre CCS. A qualidade do ar e a contribuição do sistema de ar condicionado. In: Anais do III CIAR [Congresso Ibero-Americano de Ar Condicionado e Refrigeração] e Congresso Brasileiro de Refrigeração, Ventilação e Condicionamento de Ar; 1995 Ago 29-31; São Paulo, Brasil. ABRAVA [Associação Brasileira de Refrigeração, Ar Condicionado, Ventilação e Aquecimento].

Amaral S. Afinco nos assuntos do setor e da Sociedade. Household \& Cosmetics 2002; 3 (13) (edição especial HOUSEHOLD 2002): 90-1.

[Anonymus]. Ar mais puro. Cláudia Janeiro; 2001, p.110.

Bernado Neto, A. Panorama do mercado latino-americano: limpeza caseira. [apresentado pela AC Nielsen ao $5^{\circ}$ Seminário e Expo Internacional 
para fornecedores das indústrias de Higiene e Limpeza - lar e institucional e Auto Care; 2002 jun 22 a 24 de maio de 2002; São Paulo, Brasil ].

Bicho GG; Pich T. Levantamento dos ensaios realizados por laboratórios prestadores de serviço para a gerência geral de saneantes. ANVISA Brasília; Agosto de 2001,15 p.

Bloemen HJTH, Burn J. Volatile organic compounds in the environment. Chapman Hill - Blackie Academic Professional. UK: 1995.

Brooks BO, Davis WF, 1992. Understanding indoor air quality. CRC Telford Press. Boca Raton, Florida.

Budavari S. Ed. The Merck Index. $12^{\text {nd }}$ ed.NJ: Merck Research Laboratories Division; 1996.

Burge PS, Richardson MN. Occupational asthma due to indirect exposure to lauryl dimethyl benzyl ammonium chloride used in a floor cleaner. Thorax $1994 ; 49: 842-843$.

Calabrese EJ, EM Kenyon. Air toxics and risk assessment. Lewis Publishers, chelsea, MI. 1991.

Castel SW, Vernon RJ, Bailey EM Jr. Formaldehyde: toxicology and hazards. Vet Hum Toxicol; 1987 Feb; 29(1):31-3.

CIPA - Caderno informativo de prevenção de acidentes. Ar condicionado é pior que fumo. Ano XIII- 152, 1992.

Colombo A, Bortoli MD, Knöppel $H$, Schauenburg $H$, Vissers $H$. Small chamber test and headspace analysis of volatile organic compounds emitted from household products. Indoor Air, 1991, 13-21. 
Committee on Toxicology: Formaldehyde - an assessment of its health effects. National Academy of Sciences, Washington, D.C., Março 1980.

Commonwealth of Massachusetts. Request for response \#GRO04 for cleaning products, environmentally preferable, Operational Services Division - Room 1017. Boston: May, 2001. Available from URL: http://www.comm_PASS.com.

Cosmetic, Toiletry and Fragrance Association, CTFA Microbiology Guidelines, Washington, 1993.

Crumb DR. Volatile organic compound in indoor air. In: Volatile organic compounds in the atmosphere - Issues in Environmntal Science and Technology. Hester, RE \& Harrison RM, Eds., V.4 . The Royal Society of Chemistry. Cambridge, UK: 1995.

Danish Toxicology Centre. An ABC of toxicology. Denmark: December 1992.

Dantas EHM. As Polêmicas sobre operação e controle de ar condicionado. Higipress, Mar 1999.

Dantas, EHM. Manutenção de Sistemas de Ar condicionado. [Apresentado no Simpósio de Higienização de Interiores - SINCONTHI; 2000 mai 10; São Paulo, Brasil].

Diehl KH, Eigener U, Heinzel M, Kamps T, Knauel G, Kock C (German Association for Scientific and Applied Cosmetics Microbiology and Hygiene Expert Group). Do microorganisms develop resistance to antimicrobial biocides? IFSCC Magazine 2000; 3:35-37. 
Eduardo MBP (1998). Vigilância sanitária, v. 8. São Paulo: Faculdade de Saúde Pública da Universidadade de São Paulo, 1998 (Série Saúde e Cidadania).

Environmental Protection Agency (1991). Indoor air facts No. 4 (revised): sick building syndrome (SBS). Office of Air and Radiation. April 1991. Available from URL: http://mww.epa.gov/iaq/pubs/sbs.html (16 Feb. 2002).

[EPA] Environmental Protecion Agency/USA. (1998). National volatile organic compound emission standards for consumer products. Federal Register - Rules and registrations. EPAIUSA. Vol. 63, No. 176.

[EPA] Environmental Protection Agency/USA. Health and environmental effects profile for formaldehyde. EPA $6006 x-85 / 362$. Environmental Criteria and Assessment Office, Office of Health and Environmental Assessment, Office of Research and Development, Cincinnati, OH. 1988.

[EPA] Environmental Protection Agency. Integrated risk information system (IRIS) on formaldehyde. Environmental Criteria and Assessment Office, Office of Health and Environmental Assessment, Office of Research and Development, Cincinnati, OH. 1993.

[EPA] Environmenal Protecion Agency/USA. Formaldehyde [on line]. Available from URL:http//www.epa.gov/ttn/watw/hlthef/formaldehyde.html. Jul, 2002.

Euromonitor Internacional. O Mercado brasileiro de limpeza doméstica. Happi. 2000; 39-42.

[Anonymus]. Exame (1996). Prédios doentes. São Paulo, 9 ago. 
Fisk WJ. Estudo da influência das condições ambientais sobre a produtividade e a saúde dos ocupantes de ambientes interiores. Brasindoor. 2000; 4(1): 25-26. Trad. de I Ricard.

Fortmann R, Krebs K, Marfiak S, Masom M. Sampling and analysis of VOCs for indoor air source characterization. In: [A\&WMA] Air Waste Management Association. Engineering Solutions to IAQ Problems. VIP-51. Pittsburgh: A\&WMA; 1995. 3-81.

Gioda A, Aquino Neto, F R. Uso de sensores para caracterização da qualidade do ar de interiores. Revista Brasindoor 2000a; IV(5): 4-15.

Gioda A, Aquino Neto FR. Glossário de termos utilizados para análise da qualidade do ar. Revista Brasindoor 2000b; IV(5): 16-21.

Gold DR. Indoor air pollution. Clin Chest Med 1992 Jun; 13(2):215-29.

Guillemin MP. Air contamination exposure measurements of organic solvents - past and present. Scand J Work Environ Health 1985;11 Suppl 1:33-43.

Green Seal. Standard for general-purpose, bathroom, and glass cleaners used for industrial and institutional purposes. Available from URL: htmhttp://www. greenseal.org/standard/degreaser.htmaio,

Grinover AP. Código brasileiro de defesa do consumidor: comentado pelos autores do anteprojeto. Ed. Rio de Janeiro: Forense Universitária, 2000.

Guia das Análises 2000. Química e Derivados. 35: 383; Julho 2000.

Guia de Informações Comerciais -Ano 54 - Edicão anual. Guia dos Negócios Grande São Paulo 2001. Exemplar de distribuição gratuita Edição Especial, 2001. 
Henschel B. ORD's Research activities under the Buy Clean Program. Scientist-to-scientist meeting presentation. US-EPA- RTP, NC: May 16-17, 2001.

Hospital Infection. Bennett, JV, Brachman, PS. 1979. Boston, Little, Brown and Company.

[HSDB] Hazardous Substances Databank. U.S. Departament of Health and Human Services (HSDB, online database). National Toxicology Information Program, National Libraty of Medicine, Bethseda, MD. 1993.

Htdocs. Ortho-phenylphenol and its sodium salt. Available from URL<http://193.51.164.11/htdocs/monographs/> Vol. 73 (1999), p. 451.

[IARC] International Agency for Research on Cancer. IARC monographs on the evaluation of the carcinogenic risk of chemicals to humans. Vol. 29. Some industrial chemicals and dyestuffs. Lyon, France: International Agency for Research on Cancer, pp. 345-389.

Janitorial Products - Pollution Prevention Project. Buying environmentally preferable janitorial products. (Web Site). Sponsored by US EPA and various local government commissions. Available from URL:http://www.westp2net.org/Janitorial/commentaries/buyepp.pdf (2001 May 08).

Kodak [1936-1960]. Personal observations. Rochester, NY: Eastman Kodak Company, Laboratory of Industrial Medicine. [From Patty FA, ed. [1963]. Industrial hygiene and toxicology. 2nd rev. ed. Vol. II. Toxicology. New York, NY: Interscience Publishers, Inc., p. 1971.

Kristoff, K. The anti-allergen solution Happi: November, 2000. 
Kulcsar Neto F, Siqueira LFG. Padrões referenciais para análise de resultados de qualidade microbiológica do ar em interiores visando a saúde pública no Brasil, Fundação Jorge Duprat Figueiredo de Segurança e Medicina do Trabalho - FUNDACENTRO, São Paulo, São Paulo, Brasil, 1998.

Krebs $\mathrm{K}$, Lao HC, Fortman, R. Test methods for determining short and long term VOC emissions from latex paint. In: Engeenering Solutions to Indoor Air Quality Problems. VIP 51. Air \& Waste Management Association. 1995.

Levy S. The challenge of antibiotic resistance. Scientific American 1998; March: 32-39.

Lourenço M. Uma nova geração de produtos de limpeza. Superhiper. São Paulo: 1998.

Maillard JY, Russel AD. Biocide activity: prospects for potentiation. CHIMICA OGGI/Chemistry today December 2001, p. 33-5.

Magnani LAC, Pinto FP, Assolan KRM, Moreno R. Ambientes saudáveis. Revista brasindoor 1999, f Vol.III, No. 3

Mclaughlin, T. The clening, hygiene and maintenance handbook. London, Business Books Limited. 1969, 228 p.

Mikatavage MA, Rose VE, Funkhouser E, Oestenstad RK, Dillon K, Reynolds KD. Beyound air quality-factors that affect prevalence estimates of sick building syndrome. American Industrial Hygiene Association Journal. 1995; 56:1141-1146 (November1995). 
Miller JF, Keller GE. Overview of the ACS Symposium on indoor Air Pollution. In: Kay JG et al., Indoor Air Pollution - Radon, bioaerosols, \& VOCs. Flórida: Boca Raton; 1991. Lewis Publisher. p. 3-7.

Ministério da Saúde. Sistema Nacional de Vigilância Ambiental em Saúde. [Ata de inserção do SINVAS no Sistema Único de Saúde]. Fundação Nacional de Saúde. Brasília, Novembro de 2001.

Ministério da Saúde. PORTARIA N ${ }^{\circ}$ 15, DE 23 DE AGOSTO DE 1988. Diário Oficial da União, 05/09/1988. Ministério da Saúde. GABINETE DO MINISTRO. Brasília, Brasil, 1988.

Ministério da Saúde. PORTARIA No 327, DE 30 DE JULHO DE 1997. Diário Oficial da União, 01/08/1997. Ministério da Saúde. GABINETE DO MINISTRO. Brasília, Brasil, 1997.

Ministério da Saúde. PORTARIA N³.523, DE 28 DE AGOSTO DE 1998. Diário Oficial da União, 31/08/1998. Secção 1:40-2. Ministério da Saúde. GABINETE DO MINISTRO. Brasilia, Brasil, 1998.

Ministério da Saúde. RESOLUÇÃO RE № 176, DE 24 DE OUTUBRO DE 2000. Diário Oficial da União, Ministério da Saúde. GABINETE DO MINISTRO. Brasília, Brasil, 2000.

Ministério da Saúde. Sistema Nacional de Vigilância Ambiental em Saúde. Brasília: fundação Nacional de Saúde - Coordenação de Vigilância Ambiental em Saúde, Novembro de 2001.

Moreno, JMJ. Tecnologia de los recubrimientos de superfícies. Enciclopédia de la Química Industrial - Tomo 7 - Ediciones Urmo. Bilbao, España. 1978. 822 p. 
Morrison R, Boyd R. Química orgânica . 8a. ed. Fundação Calouste Gulbenkian. Lisboa: 1983). V 3.

National Toxicology Program. One-year initiation/promotion study of oBenzyl-p-chlorophenol in swiss (CD-1) mice. U.S. Department of Health and Human Services. May 1995.

Neal SB. Preservantes: o que o usuário precisa saber. Cosmetics \& Toiletries [Edição em português]. Vol. 13, mar/abr 2001.

[NIOSH] National Institute for Occupational Safety and Health/USA. Formaldehyde: evidence of carcinogenecity [on line] Available from URL:http//umw.cdc/niosh/811134.html [Abril 15, 1981];

OECD. Guideline for testing of chemicals. No. 103. ISBN 92-64-12221-4. Paris:1981.

[OSHA] Occupational,Safety and Health Administration. Formaldehyde. [on line] Available from URL:http//www.osha-slc.gov/s/tc/formaldehyde.html

Partanen T. Formaldehyde exposure and respiratory cancer - a meta analysis of the epidemiologic evidence. Scand J Work Envron Health 19(1):8-15.

Patty FA, ed. [1963]. Industrial Hygiene and Toxicology. $2^{\circ}$ rev. ed. Vol II. Toxicology. New York, NY: Interscience Publisher, Inc. p. 1971.

Petillo VLS. Novas gerações de quaternários de amônio para desinfecção de superfícies. Total Clear. São Paulo:1999.

Petillo VLS. Gestão ambiental na indústria química brasileira - análise de 1990 a 1995. Dissertação de mestrado. 1997. 
Petillo VLS. É necessário utilizar conservante na formulação de desinfetantes? Household \& Cosmetics 2002; 3 (13) (edição especial HOUSEHOLD 2002): 90-1.

Promega. Ficha de segurança on line. Available from <URL: http://www.promega.com/msds/Portugal/PortuguezMSDS\%5CQ427.html 2000 Jul 22.

Roache N, Howard E. Characterization of the usefulness of the field and laboratory emission cell (FLEC) for the evaluation of emissions from engineered wood products. In: [A\&WMA] Air Waste Management Association. Engineering Solutions to IAQ Problems. VIP-51. Pittsburgh: A\&WMA; 1995. 3-81.

Roto P, Sala E. Occupational laringitis caused by formaldehyde: a case report. Am J Ind Med 1996 Mar; 29(30):275-77.

[RTECS]. Registry of Toxic Effects of Chemical Substances (RTECS, on line database). U.S. Departament of Health and Human Services National Toxicology Information Program, National Libraty of Medicine, Bethseda, MD. 1993.

Russel AD, Hugo WB, Ayliffe GAJ, editores. Principles and practice of disinfection, preservation, and sterilization. 3a. ed. Malden(USA): Oxforf; 1999.

Sanchez M. Metade da população terá alergias em meados do século. EI País, Espanha: 20/01/01.

Santos UP, Rumel D, Martarello N, Ferreira C, Matos MP. Síndrome dos edifícios doentes em bancários. Rev. Saúde Públ., São Paulo, 26(6): 400-4, 1992. 
Siqueira LFG. Síndrome dos edifícios doentes. SOS Revista da Associação Brasileira para Prevenção de Acidentes, São Paulo, Ano XXVII set./out 1992. P. 11-15.

Siqueira LFG, Siveira MJ, Cardoso MRA, Paula CR, Vilas Boas JH. Prevalência dos microorganismos isolados em bandeja de condensado de sistemas de ar condicionado central, instalados em hospitais, na cidade de São Paulo. In: Anais do III CIAR [Congresso Ibero-Americano de Ar Condicionado e Refrigeração] e Congresso Brasileiro de Refrigeração, Ventilação e Condicionamento de Ar; 1995 Ago 29-31; São Paulo, Brasil. ABRAVA [Associação Brasileira de Refrigeração, Ar Condicionado, Ventilação e Aquecimento].

Steinberg DC. Preservatives for cosmetics. Cosmetics \& Toiletries 1996. C\&T Ingredient resources Series.

Sterling TD, Collet C, Rumel D. [The epidemiology of "sick buildings"]. Revista de Saúde Pública, São Paulo, 25:56-63, 1991.

Universidade de São Paulo. Manual de biossegurança. Comissāo Interna de Biossegurança da FCF/USP: 2000.

USEPA. [United States Environmental Protection Agency]. Center for Environmental Research Information. Office of Research Development. U.S. [Compendium method TO-11A]. Determination of formaldehyde in ambient air using adsorbent cartridge followed by high performance liquid chromatography (HPLC) [Active sampling method]. Compendium of methods for the determination of toxic organic compounds in ambient air Compendium of Methods for the determination of Toxic Organic compounds in ambient air. Cincinnati; Janeiro, 1999a; 56 pág.

USEPA. Determination of volatile organic compounds (VOCs) in ambient air using specially prepared canisters with subsequent 
analysis by gas cromatografy. Compendium of methods for the determination of toxic organic compounds in ambient air. 2nd ed. Center of Environmental Research Information Office of Research and Development . Cincinatti: January 1999b.

U. S. General Accounting Office. Antimicrobial: data to assess public health threat from resistant bacteria are limited. Report to Congressional Requesters. GAO/HEHS/NSIAD/RCED-99-132. USA:1999.

U.S. EPA. Pesticide management [on line] Available from URL:http://www. Epa.gov/owow/NDS/MMGl/chapter2/ch2-2d.html. [1999]

Wallace LA. VOCs and the environment and public health - exposure. Volatile organic compounds in the environment. Bloemen HJTH, Burns J. UK: 1995.

Wantke F, Demmer CM, Tappler P, Gotz M, Jarisch R. Exposure to gaseous formaldehyde induces IgE-mediated sensitization to formaldehyde in schollchildren. Clin Exp Allergy 1996 Mar; 26(3): 276-80.

White, PAF. Protective air enclosures in health buildings. Hong Kong, Multiplex techniques Ltd, 1981.

[WHO] World Health Organization. Indoor air pollutants: exposure and health effects. Copenhagen, 1983. (Euro Reports and Studies, 78).

[WHO] World Health Organization. Indoor air quality: organic pollutants: report on a WHO meeting. Regional office for Europe. Copenhagen: 1987.

[WHO] World Health Organization. Environmetal health criteria for formaldehyde. Vol. 89. World Health Organization, Genebra, Suiça. 1989. 
[WHO] World Health Organization. Hazardous chemicals in human and environmental health [on line]. Available from URL:http:wuw.who.int /pcs/training_material/hazardous_chemicals/contents.htm. Documento capturado em [2002 Fev 19].

Wolkoff P, Clausen PA, Jensen B, Nielsen GD, Wilkins CK. Are we measuring the relevant indoor pollutants? Indoor air. 1997, 7: 92-106. Denmark.

Wolkoff P, Schneider T, Kildeso J, Degerth R, Jaroszewski M, Schunk H. Risk in cleaning: chemical and physical exposure. The science of the total environment. 1998; 215: 125-156.

Yocom JE, McCarthy SM. Measuring indoor air quality: a practical guide. Principles and techniques in the environmental sciences. England: John Wiley \& Sons, 1994.

Zanini AC, Oga S. Farmacologia aplicada. Vários colaboradores. Cap. 85 5a. ed. São Paulo: Atheneu, 1994. 


\section{ANEXOS}


ANEXO 1 - ROTEIRO PARA FORMULAÇÃO DE DESINFETANTES 


\section{APRESENTAÇÃO}

Os desinfetantes são produtos essenciais para a proteção da saúde humana contra a ameaça de doenças infecciosas. As autoridades sanitárias e os cidadãos estão de acordo com esta afirmação. Os fabricantes, por sua vez, empenham-se em produzir desinfetantes que atendam à demanda que esta necessidade impõe, da forma mais competitiva possivel.

Quais são os segredos dos grandes profissionais formuladores e inventores de patentes na área de produtos de limpeza? Para manter a competitividade de suas marcas, a estratégia dos fabricantes é buscar a diferenciação para seus produtos no mercado e, para isso, manter a confidencialidade das fórmulas é uma grande preocupação. A declaração da fórmula no rótulo é uma exigência legal imposta pelo Ministério da Saúde, porém, na prática, se dá apenas qualitativamente e assim mesmo por classe ou função química. Apenas a composição do sistema ativo dos desinfetantes tem que ser declarada com maior especificidade e de forma quantitativa. É por estas razões que o conhecimento de como formular desinfetantes e produtos de limpeza em geral, permanece no domínio do meio industrial não se estendendo ao meio acadêmico, governamental ou público, de maneira geral. As técnicas e conhecimentos se transmitem entre os profissionais de uma mesma empresa ou com seus fornecedores o que demanda um certo tempo até se formar um bom profissional para a área.

Mesmo os profissionais das empresas multinacionais, que possuem grandes centros de pesquisa e desenvolvimento, necessitam desenvolver produtos com características regionais. $O$ movimento de globalização trouxe o conceito de centros de desenvolvimento regionais, os chamados $R T C$ 's ou RICS (Regional Inovation Centes ou Regional Technical Centers), centros de desenvolvimento e manufatura especializados que têm como objetivo desenvolver produtos potencialmente adequados para todos os países tornando muito mais forte a preocupação com a harmonização de produtos e marcas. 
Os administradores hospitalares ou de condomínio, os supervisores de empresas limpadoras e os consumidores em geral, indagam: Como se certificar de que o desinfetante escolhido vai cumprir sua função sem causar danos à saúde?

O consumidor de produtos de uso doméstico se vê confuso diante da gôndola do supermercado lotada de dezenas de marcas e versões de desinfetantes. Os pais de crianças alérgicas, mais atentos aos dizeres de rotulagem, muitas vezes adotam o método da tentativa e erro para escolher o desinfetante mais adequado para a família. Onde encontrar orientação confiável para esta importante e difícil tarefa de escolha do desinfetante mais adequado que não comprometa a saúde?

Para responder algumas dessas perguntas e, com 0 intuito de contribuir para a transferência de conhecimento e técnica em formulação de produtos desinfetantes existentes na indústria brasileira de produtos de limpeza, foi elaborado este guia básico sobre como formular produtos desinfetantes. Nele são apresentadas algumas diretrizes que visam contemplar variáveis ambientais no seu desenvolvimento. 


\section{CAPÍtulo 1. Etapas de desenvolvimento de fórmulas de novos produtos de limpeza}

Um projeto de desenvolvimento de produto, seja ele uma simples solução sanitizante ou um desinfetante hospitalar para áreas críticas baseado num prinápio ativo inovador, deve contemplar todas as etapas que garantem o seu sucesso no sentido de chegar a uma fórmula eficaz, vendável e aprovada em termos de saúde, segurança e meio ambiente.

As etapas iniciais se referem ao planejamento do projeto. Seria a fase de gestação, na qual vai se formar a idéia da função do produto, suas características, sua aparência e a condição para que ele possa existir e entrar efetivamente na fase de desenvolvimento. Por último vem a etapa de maturação na qual o produto já está pronto mas ainda precisa de um acabamento para ser encaminhado para a fabricação e distribuição ao mercado.
É claro que todos os departamentos da empresa vão participar desse processo desde o início, mas são as atribuições de desenvolvimento do produto que vai dentro da embalagem que este roteiro vai tratar. Ou seja, atribuições do formulador, técnico de desenvolvimento, gerente de inovação ou outro nome que esta função pode receber nas mais diversas empresas.

Destaque deve ser dado à segunda fase, que é a de desenvolvimento propriamente dita. Ela tem caráter cíclico, ou seja, se o resultado desejado não é alcançado por razões técnicas, de segurança, regulamentação etc. as premissas do projeto têm que ser revistas. Volta-se portanto ao início do cido e os testes de laboratório, avaliações etc., têm que ser repetidos. É um ciclo do tipo planeja-executa-verifica-corrige.

O número de repetições deste ciclo é proporcional à complexidade do projeto e inversamente proporcional à qualidade do seu planejamento e gerenciamento. Portanto o 
desenvolvimento de um desinfetante é um processo bastante dinâmico.

O tempo de conclusão e o custo do processo de desenvolvimento são interdependentes. Se a necessidade de concluir o projeto é urgente, torna-se necessário investir mais em recursos técnicos, humanos e financeiros. Geralmente estas variáveis têm que ser adequadas aos recursos do projeto propriamente dito, do departamento ou célula de desenvolvimento e aos fatores externos. O principal fator externo é a competitividade. Quando, numa categoria de produto, há alguma necessidade não satisfeita, ou seja, uma oportunidade de mercado, chegar primeiro, de forma rápida e diferenciada é a chave do sucesso. Esta noção de mercado deve ser conhecida e entendida pelo pessoal técnico para que 0 suporte prestado, em conjunto com as áreas de suprimento e manufatura, às áreas de marketing $\mathrm{e}$ vendas, seja o mais efetivo possível.

Uma maneira de acelerar o processo de desenvolvimento, é abrir mais do que uma frente de trabalho, considerando várias alternativas de fórmula para, no final, adotar aquela que mais se enquadra às premissas do projeto e/ou ao mercado. Isto requer maior investimento sob todos os aspectos e, principalmente, boa capacidade de gerenciamento, entretanto este é um recurso muito válido para se poupar tempo e garantir o sucesso do projeto.

A preocupação com saúde, segurança e meio ambiente para quem desenvolve produtos químicos é crescente. Mesmo que o momento num determinado país ou região não exija os mais altos padrões de desempenho de produto com relação a estes fatores, a globalização é uma realidade que impulsiona as mudanças e adaptações das fórmulas. As agências de vigilância sanitária e outros órgãos oficiais freqüentemente impõem novas regulamentações, assim como as organizações independentes, associações comerciais, grupos de consumidores e ambientalistas, e o público em geral, pressionam para que a sociedade possa cada vez mais, contar com produtos responsáveis, ou seja, que não causem impacto na saúde humana e ambiental como um todo. O importante é que não se pode perder de vista a prática dos preceitos da sustentabilidade do desenvolvimento. 


\section{Planejamento da formula}

Raramente se inicia o desenvolvimento de uma fórmula diretamente na bancada do laboratório, misturando as matéria-primas. Embora o trabalho empírico possa levar a resultados interessantes em determinadas etapas do desenvolvimento, sem um planejamento de fórmula, não é raro acontecer desperdícios de materiais, tempo e esforço sem se chegar a um resultado satisfatório. É necessário primeiramente efetuar um estudo para definir os componentes da fórmula de acordo com sua função.

Um dos primeiros fatores a considerar no planejamento da fórmula são as exigências de regulamentação. Estas exigências tornaram-se um item muito restritivo devido à harmonização de fórmulas que as empresas multinacionais praticam entre seus centros de pesquisa para que o portifólio seja o mais racional possivel.

Compete ao Ministério da Saúde regulamentar o mercado de produtos saneantes e conceder registro de fórmulas. Também é responsabilidade da vigilância sanitária, autorizar a fabricação de fórmulas de acordo com as normas estabelecidas em saúde, segurança e meio ambiente bem como fiscalizar a prática dessas fórmulas.

Para os desinfetantes, destaca-se a Portaria MS N ${ }^{\circ}$ 15/1988 que deve ser consultada e seguida pelo formulador. Deve-se ainda ter em mente que, para se obter produtos ambientalmente preferíveis, padrões de segurança acima das exigências legais devem ser praticados desde 0 planejamento da fórmula até a fabricação do produto, o quanto possível.

Outro fator fundamental na fase de planejamento da fórmula é o conhecimento das matérias-primas. Para isso os fornecedores podem ser tomados como primeira fonte de informação. Com base na função do produto que se quer formular, deve-se definir quais são as matérias-primas necessárias, sua proporção na fórmula $e$ as incompatibilidades entre elas. $\mathrm{O}$ princípio ativo desinfetante é o ponto de partida para se iniciar o estudo das incompatibilidades, pois seu caráter iônico definirá também o restante dos componentes da formulação. Por exemplo, se o processo de higienização conta com uma etapa de limpeza prévia à base de detergente aniônico, a formulação do 
desinfetante não poderá ser catiônica. Portanto, os sais quaternários de amônio não poderiam ser utilizados neste caso.

Deve-se exigir do fornecedor de matérias-primas que 0 folheto técnico e a ficha de segurança de produtos quimicos (FISPQ) acompanhem sempre as amostras solicitadas para a preparação dos protótipos de laboratório e das preparações em escala piloto. 


\section{Capítulo 2. PRINCÍPIOS BÁSICOS}

Pelo fato do conhecimento e das técnicas serem gerados nos laboratórios dos fabricantes, de forma muitas vezes empírica, diferencia-se o profissional que procurar adquirir conhecimentos teóricos e manter-se atualizado.

Para a escolha do tipo e concentração dos princípios ativos que vão compor o sistema desinfetante do produto, é necessário antes de tudo, conhecer o mecanismo de ação dos biocidas.

Os biocidas compreendem uma série extensa de agentes químicos. Esta diversidade oferece várias possibilidades de interações destrutivas com a célula do microorganismo. Geralmente a morfologia e fisiologia da célula combinadas com as propriedades físico-químicas do biocida, definem pontos ou regiões específicas de lesão, cujo conhecimento se contitui numa poderosa ferramenta para a busca da melhoria da capacidade biocida dos agentes químicos existentes e de novas moléculas (Denyer, 1995). Este é o ponto de partida para quem quer aprender a formular produtos desinfetantes.
Um assunto que geralmente desperta discussões é a questão da necessidade de incluir um conservante na fórmula dos desinfetantes.

A escolha correta do tipo e concentração de ativo aliada à conformidade com as normas de boas práticas de fabricação elimina a necessidade de se adicionar um conservante à fórmula do desinfetante e o consequente acréscimo no custo do produto. Os dois aspectos mais importantes a considerar são as práticas de fabricação do produto e a qualidade do princípio ativo desinfetante. Partindo-se do princípio de que um conservante não deve nunca compensar más práticas de fabricação e que a qualidade da matéria-prima desinfetante é assegurada, não se deve incluir um conservante na fórmula dos desinfetantes.

Este assunto volta à pauta de discussão quando casos de desinfetantes contaminados microbiologicamente são detectados no mercado. É verdade que a função do conservante nos mais diversos tipos de formulação é inibir o crescimento de microorganismos no próprio produto, protegendo-o de contaminações microbiológicas provenientes da sua produção ou até mesmo do seu uso pelo próprio 
consumidor, conforme se pode comprovar através dos testes de desafio. Uma produção de acordo com as Boas Práticas de Fabricação (BPF), contemplando todos os seus ítens como água, matérias-primas, processos de sanitização validados, controle microbiológico, planta e equipamentos adequados, bem como a capacitação dos operadores e o comprometimento de toda a organização, garante um produto de boa qualidade microbiológica na saida da linha de produção, minimizando o papel do conservante. Por outro lado, se eventualmente o consumidor contaminar 0 produto durante 0 uso, 0 conservante irá protegê-lo durante todo o seu prazo de validade.

Um produto desinfetante no entanto, já possui um ativo microbiocida presente na formulação cuja função é matar formas vegetativas de microorganismos nas superfícies a serem desinfetadas. Sendo este de amplo espectro e estando em concentração adequada e comprovada em testes, a qualidade do produto estará assegurada, dispensando 0 uso do conservante nas plantas de produção que possuem as BPFs. O princípio ativo estará então livre para agir contra os microorganismos patogênicos e não contra aqueles provenientes das más práticas de fabricação.

Não há dúvida que a atividade dos biocidas pode ser continuamente melhorada, porém é crucial partir do conhecimento da fisiologia e susceptibilidade dos microorganismos e dos mecanismos de ação das moléculas para desenvolver combinações sinérgicas e seguras. Por exemplo, a otimização das fórmulas de desinfetantes requer o conhecimento dos tipos de quaternários quanto ao tamanho de cadeia, fator que influencia na solubilidade, irritabilidade e eficácia do produto final. Para os quaternários de amônio, o comprimento das cadeias $\mathrm{C}_{14}$ apresenta a melhor eficiência para os alquis, já para os dialquis, cadeias geminadas de $C_{10}$ apresentam melhor desempenho.

É comum encontrar linhas de produção sem controle microbiológico, tanques de estocagem de água sem agitação, matérias-primas de baixa qualidade, sanitização aplicada com baixa ou nenhuma frequência, o que acaba por promover a formação de biofilmes e comprometer a qualidade do produto, ou seja a eficácia desinfetante. Se a contaminação durante a 
fabricação é elevada, a concentração de ativo presente na formulação será reduzida, tornando-se subletal. Além do produto perder a sua eficácia, o mais grave é que isto irá contribuir para a seleção de cepas resistentes, o que em suma, representa uma ameaça à Saúde Pública. Nestes casos, faz-se necessário arcar com o custo da adição de um conservante no desinfetante.

De fato, 0 aspecto de maior importância sob a responsabilidade do fabricante reside na escolha do tipo de ativo, a qual deve ser muito criteriosa. Na etapa de desenvolvimento da fórmula, deve-se levar em conta o espectro de ação do ativo de acordo com a finalidade do produto (uso doméstico ou hospitalar), a sua compatibilidade com os componentes da formulação, a faixa ótima de $\mathrm{pH}$, lembrando que o ativo deve ser utilizado em concentração adequada e cuidados devem ser tomados para não inativá-lo por fatores como presença de água dura, matéria orgânica, substâncias da formulação que se comportam como inativantes, temperatura, alteração de $\mathrm{pH}$, etc. Antes da etapa de fabricação, é necessário confirmar os resultados do certificado de análise do princípio ativo quando do controle de qualidade no recebimento das matérias-primas. Mesmo quando o fornecedor é certificado e as suas instalações foram inclusive visitadas, este controle deve ainda ser feito em frequências menores como spot-sheck.

A escolha correta do tipo e concentração de ativo aliada à conformidade com as normas de boas práticas de fabricação elimina a necessidade de se adicionar um conservante ao desinfetante e o consequente acréscimo no custo do produto. Por fim, cabe aos profissionais de Marketing, em conjunto com os da área técnica, trabalhar para que as instruções de uso sejam claras, contemplem informação sobre diluição, possiveis inativantes, tempo de contato e assegurem o uso correto do produto pelo consumidor. 


\section{Capítulo 3. ROTEIRO PARA FORMULAÇÃO DE DESINFETANTES}

Conforme introduzido no capítulo 1 , segue abaixo 0 roteiro com todas as etapas de desenvolvimento de desinfetantes.

I. PLANEJAMENTO

I.1. Pesquisa de mercado
a. Segmentação do mercado
b. Tendências
c. Hábitos do consumidor

I.2. Pesquisa de fórmulas

I.3. Planejamento da fórmula

\section{DESENVOLVIMENTO}

II.1. Formulação preliminar

II.2. Análise regulatória para registro da fórmula

II.3. Preparação de protótipos

II.4. Análise dos aspectos de saúde, Segurança e Meio Ambiente

II.5. Avaliação de estabilidade da fórmula

II.6. Avaliação de compatibilidade com a embalagem

I1.7. Avaliação de eficácia (Teste de diluição em uso)

II.8. Avaliação de performance geral

II.9. Avaliação sensorial

II.10. Avaliação de inocuidade

II.11. Avaliação ambiental
a. Impactos em corpos d'água
b. Impactos na qualidade do ar interior
c. Análise do ciclo de vida do produto 
II. 12. Avaliação de saúde e segurança

\section{II.13. Avaliações de eficácia}

II.14. Teste de compatibilidade com a embalagem

II.15. Aplicação de patentes

II.16. Teste em uso
a. Painéis de teste
b. Pesquisa de Mercado
c. Lançamento em área-teste

II.17. Ajustes de formulação e retorno para etapa II.2 , caso necessário.

\section{FINALIZAÇÃO}

III.1. Aprovação da fórmula

III.2. Comissionamento de produção

III.3. Aprovação de dizeres de rotulagem e campanha de comunicação
III.4. Treinamento técnico para Vendas e Serviço de Atendimento ao Consumidor

III.5. Acompanhamento de lançamento

III.6. Acompanhamento de vendas

III.6. Atendimento ao Consumidor

O trabalho de desenvolvimento tem uma importante interface com a fábrica, que é a implementação das Boas Práticas de Fabricação. O formulador tem importantes observações a fazer com esse objetivo, facilitando o trabalho do pessoal de fábrica.

Na interface com o trabalho de Marketing, o incentivo do uso correto de desinfetantes pode se dar através de um bom trabalho feito na definição das instruções de uso. Trata-se de uma responsabilidade do fabricante e especialmente do formulador. $O$ profissional de marketing precisa submeter à revisão técnica, o seu trabalho de criação relacionado com rotulagem e comunicação . A questão da linguagem de comunicação pode induzir a erros ou exageros, os quais precisam ser evitados. Não se trata de propaganda enganosa, 
mas a veiculação correta ajudará a promover a venda do produto por longo tempo.

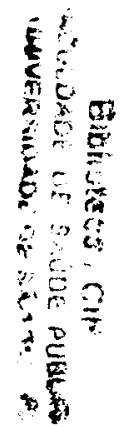




\section{Capítulo 4. OTIMIZAÇÃo}

Para manter a competitividade do produto no mercado, faz-se necessário mantê-lo atualizado quanto às novas tendências e ações da concorrência. As formas de atualização mais importantes neste mercado se resumem nas seguintes palavras: pesquisa e monitoramento. Pesquisar o mercado lendo as publicações e participando de cursos e eventos do setor. Monitorando as fórmulas do mercado, mudanças e inovações através da abertura de fórmula.

A periodicidade de monitoramento irá depender da dinâmica do mercado em lançar novidades e dos projetos de interesse. Em função disso, define-se os segmentos que serão amostrados $e$ as marcas que serão consideradas.

Cabem aqui alguns comentários sobre estratégias de abertura de fórmula. Apesar do avançado desenvolvimento da instrumentação química-analítica, nem sempre o "segredo industrial" pode ser plenamente desvendado. $O$ resultado que se pode alcançar é na verdade a fórmula mais provável do produto. A explicação é que, em se tratando de misturas complexas, as interação ou reações que acontecem no produto, muitas vezes torna difícil a descoberta de quais foram os componentes originalmente misturados. A outra explicação é sem dúvida a existência de limites de capacidade da instrumentação analítica. As interferências analíticas e limites de detecção, que cada aparelho apresenta, determinam desvios nos resultados finais. A fórmula mais provável será obtida com boa margem de certeza e numa relação de custo e prazo interessantes, quando as seguintes etapas de trabalho forem bem planejadas e executadas:

\section{Etapas do levantamento de fórmula provável}

- Informações preliminares

Se alguém desafia 0 analista de fórmulas entregando-lhe um frasco de amostra nas mãos com a simples indagação $O$ que é e quanto tem? Ou seja qual é a composição qualitativa e quantitativa do produto, certamente terá dificuldades para obter uma resposta. Será uma questão de tempo ou de custo. 
As instruções dos dizeres de rotulagem podem fornecer importantes dicas.

- Relação dos dados necessários

Algumas vezes, uma análise qualitativa de ativo pode ser suficiente. Noutros casos, é preciso um levantamento mais aprofundado. Portanto é importante definir bem 0 problema. É qualitativo e quantitativo?

Geralmente o que se quer descobrir numa fórmula é a composição do sistema tensoativo, compreendendo o agente biocida e o detergente. Dependendo do apelo explorado pela marca, pode se desejar determinar outros componentes.

- Levantamento de informações de rótulo

- Dados físico-químicos

- Procedência

Pode dar uma idéia do grau de qualidade do produto.

- Preparação da amostra para análise
Separações por peso molecular através de

Colunas, filtrações, extrações, etc.

- Definição da estratégia analítica

Este é um trabalho que tipicamente se sabe como começa mas não se sabe como vai terminar. $A$ informação obtida numa análise alimenta o fluxo/estratégia de descoberta. Nunca será uma única análise que desvendará a composição do produto, mas sim a combinação inteligente de medições, diferentes análises e técnicas, que nos levará às respostas que buscamos.

- Técnicas titulométricas

- Técnicas cromatográficas

- O problema das interferências (superposição de picos)

- Cuidados com as colunas

- Técnicas sofisticadas

Geralmente é mais indicado comprar serviço nesta área, quando a abertura de fórmula o exigir . 
- Validações, Contra-prova, Procedimentos Operacionais Padrão

Devem ser tomados todos os cuidados para garantir a qualidade e rastreabilidade dos resultados.

- Registro de dados e resultados; identificação de amostras; relatórios; organização dos materiais.

É fundamental registrar os resultados dos testes pois o volume de informação manipulado é muito grande.

Muitas vezes o trabalho de otimização de fórmulas se inicia pela visão crítica daquele que indaga sobre a necessidade da presença de um componente que o formulador antecessor introduziu na fórmula do produto.

Mudar o sistema ativo desinfetante, por exemplo, é uma tarefa que exige cautela, porém não fazê-lo por conta dos riscos envolvidos, pode significar a perda de excelentes oportunidades de inovação e melhoria de qualidade. 0 importante é que os testes de eficácia sejam repetidos sempre que cada alteração for efetuada. É necessário também repetir esses testes com produtos obtidos de fábrica. Para a fase preliminar de testes pode-se contar com a assistência técnica que muitos fornecedores oferecem.

\section{Capítulo 5. Desinfetantes AMBIEnTALMEnTE PReferívers}

Todos os meses, centenas de toneladas de desinfetantes são lançados ao esgoto. Algumas substâncias tóxicas neles presentes podem atingir corpos d'água e até mananciais de abastecimento de água potável. Além disso, os produtos de limpeza são os produtos químicos mais envolvidos em intoxicação humana: cerca de $9 \%$ dos casos registrados pelo Sistema Nacional de Informações Toxico-farmacológicas (SINITOX) em 1999, superados apenas pelos medicamentos, $28 \%$. Uma parte das substâncias tóxicas podem volatilizar para o ambiente interior e afetar mucosa e sistema respiratório.

O que são desinfetantes ambientalmente preferiveis?

Escolher um desinfetante entre as marcas existentes na gôndola do supermercado ou entre os oferecidos pelos diversos fornecedores de produtos institucionais e industriais, pode envolver uma série de parâmetros de comparação, além 
de preço e desempenho. Entre eles, estão os fatores ambientais. Optar por um desinfetante ambientalmente superior, seguro ou preferível, pode beneficiar o meio ambiente em pelo menos sete aspectos.

1. Menos efeitos adversos à saúde ambiental e humana provenientes de compostos tóxicos. Alguns produtos de limpeza contêm substâncias químicas, que podem matar a vida aquática e causar danos ao ser humano. Por exemplo, produtos contendo hipoclorito de sódio ou amônia podem irritar os pulmões e não são recomendados para pessoas com problemas crônicos respiratórios e de coração.

\section{Menor destruição do ecossistema por substâncias químicas} persistentes. Componentes de produtos de limpeza que se biodegradam lentamente ou de forma incompleta podem colocar em risco, plantas, animais e microorganismos que vivem em sistemas aquáticos.
3. Menor liberação de substâncias tóxicas nos processos de fabricação de produto final ou intermediários. Por exemplo, alguns componentes de produtos de limpeza são obtidos da extração do petróleo e os processos de refino liberam benzeno e outros compostos tóxicos para o meio ambiente.

4. Menor risco no sistema de tratamento de resíduos sólidos municipais. Produtos de limpeza contendo compostos perigosos podem provocar impacto no meio ambiente, porque este sistema não é planejado para receber determinados resíduos perigosos, ainda que em volumes mínimos.

5. Menor esgotamento da camada de ozônio e smog fotoquímico. Alguns componentes de limpadores, tais como os Compostos Orgânicos Voláteis (COVs), contribuem para o smog fotoquímico.

6. Menos lixo. As embalagens de produtos de limpeza provocam impacto ambiental. Por exemplo, embalagens secundárias e frascos que não são reutilizados para refill vão 
desnecessariamente para aterros sanitários (ou lixões) e incineradores.

7. Menor possibilidade de formação bactérias resistentes. A subdosagem do princípio ativo pelo uso do produto diluído para limpeza pode gerar microorganismos resistentes, que ameaçam a saúde.

Esses benefícios do desinfetante ambientalmente preferivel, que se referem tanto ao ambiente interior quanto exterior, podem ser traduzidos em padrões referenciais para a categoria de desinfetantes. Uma proposta do que seriam estes padrões referenciais é apresentada na sequência.

PROPOSTA DE PADRÕES REFERENCIAIS PARA DESINFETANTES AMBIENTALMENTE PREFERÍVEIS

1. Padrões ambientais específicos do produto

1.1. Toxicológicos: não pode conter substâncias consideradas carcinogênicas ou teratogênicas conforme as principais listas negativas de produtos existentes no mundo.

1.2. Ecotoxicológicos: não pode apresentar toxicidade para a vida aquática: aguda para Dhaphnia ou peixe, aguda para algas e crônica para Daphnia.

1.3. Biodegradabilidade: cada componente do produto deve apresentar biodegradação sob condições aeróbicas de acordo com método recomendado e limite estipulado.

1.4. Fosfatos e fosfonatos não devem estar presentes em concentrações acima de $0,5 \%$ por peso de fósforo total.

1.5. As concentrações de metais pesados no produto puro não devem exceder as concentrações especificadas a seguir:

- $\quad 0,02 \mathrm{mg} / \mathrm{L}:$ mercúrio;

- $0,1 \mathrm{mg} / \mathrm{L}$ : cádmio;

- $0,5 \mathrm{mg} / \mathrm{L}$ : chumbo, crômio, níquel, arsênico e selênio.

1.6. Não pode conter lenços ou toalhas descartáveis.

1.7. Não pode conter Compostos Orgânicos Voláteis em concentrações acima de $5 \%$ de peso do produto 
conforme método estabelecido ou demonstrado através da fórmula quantitativa.

Este último item é importante porque a presença de compostos tóxicos em concentrações que possam causar danos à saúde, agudos ou crônicos, determina a qualidade química do ar para os ocupantes do ambiente. A toxicidade do produto é um requisito já exigido para registro de produto. Compostos carcinogênicos não podem ser utilizados e há critérios de avaliação toxicológicas que têm que ser obedecidos (Ministério da Saúde, 1988). Entretanto, formuladores e ambientalistas não consideram em seu trabalho a verificação da volatilidade do produto final. Ao planejar os tipos de matérias-primas que se pretende incluir na fórmula, deve-se dedicar atenção especial aos compostos leves ou de cadeia curta, verificando o seu peso molecular e pressão de vapor e que ao mesmo tempo apresentem alta toxicidade. Ao final deve-se avaliar a volatilidade do produto. Serão preferidos os desinfetantes não voláteis ou com baixa taxa de volatilidade e toxicidade.
Os Compostos orgânicos Voláteis comumente utilizados na formulação de desinfetantes estão relacionados a seguir.

\begin{tabular}{|c|c|c|}
\hline Funçăo & Classe & Exemplo \\
\hline Solventes & $\begin{array}{l}\text { Álcoois, } \\
\text { Glicóis }\end{array}$ & $\begin{array}{l}\text { Etanol, polietilenogli- } \\
\text { col }\end{array}$ \\
\hline Biocidas & $\begin{array}{l}\text { Aldeidos, éter } \\
\text { difenílico }\end{array}$ & $\begin{array}{l}\text { Formaldeído, } \\
\text { glutaraldeído }\end{array}$ \\
\hline Óleos & $\begin{array}{l}\text { Terpenos e } \\
\text { terpeneóis }\end{array}$ & Óleo de Pinho \\
\hline Perfume & $\begin{array}{l}\text { Aldeidos, } \\
\text { álcoois, } \\
\text { compostos } \\
\text { cíclicos de alto } \\
\text { peso } \\
\text { molecular etc. }\end{array}$ & Vários \\
\hline
\end{tabular}


2. Padrões ambientais especificos da embalagem

2.1. Não pode conter tintas, corantes, pigmentos ou qualquer outro aditivo contendo chumbo, cádmio, mercúrio ou crômio hexavalente.

2.2. A soma das concentrações desses metais presentes em qualquer parte da embalagem não deve exceder 100 ppm por peso.

2.3. Usar embalagens recicláveis, feitas de material recuperado e que possam ser novamente cheias com produto pelo consumidor.

2.4. Embalagens aerossol devem trazer aviso de que podem ser coletadas e recicladas e que os programas de reciclagem estão disponiveis nas áreas onde é comercializado.

2.5. Embalagens secundárias não devem ser utilizadas no ponto de venda a menos que o produto seja concentrado.
3. Padrões de performance

O produto tem que ser aprovado de acordo com o teste de diluição em uso (método padrão OECD) para os microorganismos estipulados de acordo com a finalidade de aplicação.

4. Texto de rotulagem

O produto não deve ser recomendado para uso acima da diluição para o qual está aprovado microbiologicamente.

As instruções para aplicação do produto devem estar claramente descritas no rótulo.

Frases de advertência e recomendações para usar o produto em ambiente ventilado devem fazer parte dos dizeres de rotulagem.

O princípio básico do desenvolvimento de fórmulas ambientalmente preferiveis é evitar o uso de componentes desnecessários. 
Para que estes padrões possam ser validados, devem ser submetidos à consulta pública. Após revisão e comentário por parte dos fabricantes de matérias-primas, fabricantes de produto para consumo, agência de vigilância sanitária, agência de vigilância ambiental e organizações independentes como associações de classe, de consumidores bem como sociedades cientificas etc., estes padrões podem então ser adotados.

É recomendável que a certificação do desinfetante seja feita por uma organização independente da Indústria e do Governo. Esta prática ainda não é comum no Brasil, porém uma proposta que poderia ser trabalhada é a certificação através do INMETRO ou núcleos de pesquisa da Universidade. Desta forma, as marcas certificadas levariam um selo de certificação em seu rótulo.

Finalmente, devemos nos conscientizar de que o uso excessivo de desinfetantes no meio ambiente é desnecessário e indesejável, podendo alterar a flora natural, o que irá naturalmente selecionar organismos resistentes a agentes antimicrobianos, como já acontece hoje em dia com a Pseudomonas aeruginosa, que é extremamente perigosa para individuos susceptíveis. O uso de desinfetantes pode ser minimizado ou até substituído, conforme o caso, por bons métodos de limpeza ou por métodos físicos e de esterilização.

\section{Fontes de pesquisa e atualização}

Seguem algumas recomendações de fontes de pesquisa.

- Feiras e Congressos (Household \& Auto Care)

- Estados Unidos: EPA

- Europa: ECC, COLIPA

- Associações: ABIPLA, ABRALIMP; ABIQUIM;

- Fornecedores: produtos de consumo e matérias-primas 


\section{BIBLIOGRAFIA}

Denyer, SP, 1995. Mechanisms of Action of Antibacterial Biocides. International Biodeterioration \& Biodegradation (1995) p. 227-245. Copyright 1996 Elsevier Science Limited. Printed in Great Britain.

Janitorial Products-Pollution Prevention Project. Buying Environmentally Preferable Janitorial Products. Sponsored by US EPA and various local government commissions. Available from URL:http://www.westp2net.org [2001, May].

Sites de interesse:

unw.anvisa.gov.br

wnw.iarc.fr

www.p2.org

wuw.atsdr.cdc.gov 


\section{Anexo 2 - Possíveis fontes de poluentes químicos}

As principais medidas de correção em ambientes interiores são recomendadas conforme a Resolução MS № 176/2000.

\begin{tabular}{|c|c|c|}
\hline $\begin{array}{l}\text { Agentes } \\
\text { químicos }\end{array}$ & $\begin{array}{l}\text { Principais fontes em } \\
\text { ambientes interiores }\end{array}$ & $\begin{array}{c}\text { Principais medidas de correção em } \\
\text { ambientes interiores }\end{array}$ \\
\hline $\mathrm{CO}$ & $\begin{array}{l}\text { Combustão (cigarros, } \\
\text { queimadores de fogōes e } \\
\text { veículos automotores). }\end{array}$ & $\begin{array}{l}\text { Manter a captação de ar exterior com baixa } \\
\text { concentração de poluentes; restringir as fontes de } \\
\text { combustão; manter a exaustão em áreas em que } \\
\text { ocorre combustão; eliminar a infiltração de CO } \\
\text { proveniente de fontes extemas; restringir o tabagismo } \\
\text { em áreas fechadas. }\end{array}$ \\
\hline $\mathrm{CO}_{2}$ & $\begin{array}{l}\text { Produtos de metabolismo } \\
\text { humano e combustão. }\end{array}$ & $\begin{array}{l}\text { Aumentar a renovação de ar externo; restringir as } \\
\text { fontes de combustāo e o tabagismo em áreas } \\
\text { fechadas; eliminar a infiltração de fontes externas. }\end{array}$ \\
\hline $\mathrm{NO}_{2}$ & Combustāo. & $\begin{array}{l}\text { Restringir as fontes de combustão; manter a exaustão } \\
\text { em áreas em que ocorre combustão; impedir a } \\
\text { infiltração de } \mathrm{NO}_{2} \text { proveniente de fontes externas; } \\
\text { restringir o tabagismo em áreas fechadas. }\end{array}$ \\
\hline $\mathrm{O}_{3}$ & $\begin{array}{l}\text { Máquinas copiadoras e } \\
\text { impressoras a laser. }\end{array}$ & $\begin{array}{l}\text { Adotar medidas especificas para reduzir a } \\
\text { contaminação dos ambientes interiores, com exaustão } \\
\text { do ambiente ou enclausuramento em locais exclusivos } \\
\text { para os equipamentos que apresentem grande } \\
\text { capacidade de produção de } \mathrm{O}_{3} \text {. }\end{array}$ \\
\hline Formaldeido & $\begin{array}{l}\text { Materiais de acabamento, } \\
\text { mobiliário, cola, produtos de } \\
\text { limpeza domissanitários }\end{array}$ & $\begin{array}{l}\text { Selecionar os materiais de construção, acabamento e } \\
\text { mobiliário que possuam ou emitam menos } \\
\text { formaldeído; usar produtos domissanitários que não } \\
\text { contenham formaldeído. }\end{array}$ \\
\hline $\begin{array}{l}\text { Material } \\
\text { particulado }\end{array}$ & Poeira e fibras. & $\begin{array}{l}\text { Manter filtragem de acordo com NBR-6402 da ABNT; } \\
\text { evitar isolamento termo-acústico que possa emitir } \\
\text { fibras minerais, orgånicas ou sintéticas para o } \\
\text { ambiente climatizado; reduzir as fontes internas e } \\
\text { externas; higienizar as superficies fixas e mobiliários } \\
\text { sem o uso de vassouras, escovas ou espanadores; } \\
\text { selecionar os materiais de construçåo e acabamento } \\
\text { com menor porosidade; adotar medidas especificas }\end{array}$ \\
\hline
\end{tabular}


para reduzir a contaminação dos ambientes interiores

(vide biológicos);

restringir o tabagismo em áreas fechadas.

\begin{tabular}{|c|c|c|}
\hline Fumo de tal & $\begin{array}{l}\text { Queima de cigarro, charuto, } \\
\text { cachimbo, etc. }\end{array}$ & $\begin{array}{l}\text { Aumentar a quantidade de ar externo admitido para } \\
\text { renovação e/ou exaustão dos poluentes; restringir o } \\
\text { tabagismo em áreas fechadas. }\end{array}$ \\
\hline $\mathrm{COV}$ & $\begin{array}{l}\text { Cera, mobiliário, produtos } \\
\text { usados em limpeza e } \\
\text { domissanitários, solventes, } \\
\text { materiais de revestimento, } \\
\text { tintas, colas, etc. }\end{array}$ & $\begin{array}{l}\text { Selecionar os materiais de construção, acabamento, } \\
\text { mobiliário; usar produtos de limpeza e domissanitários } \\
\text { que não contenham cov ou que não apresentem alta } \\
\text { taxa de volatilização e toxicidade. }\end{array}$ \\
\hline COS-V & $\begin{array}{l}\text { Queima de combustiveis e } \\
\text { utilização de pesticidas. }\end{array}$ & $\begin{array}{l}\text { Eliminar a contaminação por fontes pesticidas, } \\
\text { inseticidas e a queima de combustíveis; manter a } \\
\text { captação de ar exterior afastada de poluentes. }\end{array}$ \\
\hline
\end{tabular}

Fonte: Revista Brasindoor. Vol IV, No. 4, 2000 - p.9. 


\section{ANEXO 3 - Arranjo físico e sistema de ventilação dos sanitários}

Representação esquemática da planta do andar e códigos adotados:

$\mathrm{F}$

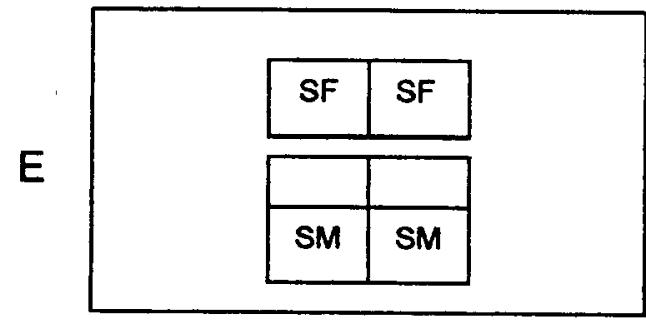

$T$

\author{
E: Lado esquerdo \\ D: Lado direito \\ D \\ T: Setor Traseiro \\ F: Setor Frontal \\ SF: Sanitário Feminino \\ SM: Sanitário Masculino
}

Sistema de ventilação

Consiste de um plenum de ar com um ventilador de exaustão Torim VEX01/02/2 modelo BDM-559-559 com vazão de ar de $18.400 \mathrm{~m}^{3} / \mathrm{h}$ instalado no topo do prédio de 9 andares de tal maneira que o ar limpo é captado dos sistemas de ar condicionado do edifício através das grelhas da porta, percorre o sanitário e sobe para o topo através das aberturas ao redor do teto dos sanitários para ser descartado.

Ärea física dos sanitários:

Altura: $2,65 \mathrm{~m}$

Comprimento: 4,70 m lado direito, 4,00 m lado esquerdo

Largura: 3,40 traseiro, $2,50 \mathrm{~m}$ frontal

A porta está posicionada no quadrado.

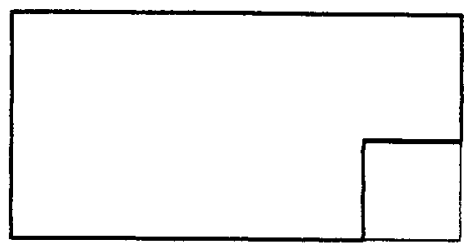




\section{GLOSSÁRIO}

Ambiente público e coletivo. Espaço fisicamente determinado e aberto à utilização de muitas pessoas. Ambiente interior ao qual a população tem acesso; destinado a ocupação comum, não especial (Ministério da Saúde, 2000).

Ativo. Ver ingrediente ativo.

Bactericida. Substância que mata as formas vegetativas das bactérias (não esporulada). Utilizado para controlar/evitar enfermidades bacterianas nos seres humanos e plantas. Ver esporo.

Biocida. Designação genérica de substância que inibe o crescimento de microrganismos, ou que os extermina.

Biofilme. Filme ou camada de microorganismos, principalmente bactérias, que se desenvolve a partir de células de diferentes espécies aderidas em superfícies. Nesta forma de desenvolvimento, as bactérias exibem características que podem ser muito diferentes daquelas das mesmas células desenvolvidas em suspensão (células planctônicas), inclusive podem apresentar reduzida sensibilidade a agentes antimicrobianos.

Breaktrough. Perda de material por saturação do elemento coletor. Ver dual bed tube.

Coadjuvante. Componente complementar de um detergente ou congênere (do mesmo gênero). Linguagem do setor de produtos de limpeza, geralmente inorgânico; acrescenta suas propriedades particulares àquelas dos componentes básicos com o objetivo de melhorar sua eficiência nas condiçoões de uso. Definição ANVISA.

Colóide. Sistema físico-químico que contém duas fases, uma das quais, a fase dispersa, está extremamente subdividida e imersa na outra, a fase dispersora. As partículas da fase dispersa (micelas) podem ter dimensões que variam, aproximadamente, entre $5 \times 10^{-5} \mathrm{~cm} \mathrm{e} 10^{-7} \mathrm{~cm}$. 
Conservante. Componente de fómula de produtos domissanitários cuja função é inibir o crescimento de microorganismos no próprio produto durante a armazenagem e uso.

Custo em uso. Conceito de Marketing. Quantia ou valor pago por um produto, considerado o seu rendimento ou outro benefício relevante para o consumidor. Conceito distinto de preço, que é o que se paga por algo posto à venda. Ex.: Um produto de limpeza concentrado pode ter um baixo custo em uso, embora tenha preço mais alto do que um produto pronto para usar, pois a quantidade necessária para a limpeza é menor, ou seja, o seu rendimento é maior.

Desinfetante. Substância que destrói, mata ou inativa a forma vegetativa (não-protegida em forma de esporos) de microorganismos danosos. São empregados intencionalmente contra os microorganismos. As formulaçōes que têm na sua composição, substâncias químicas microbiocidas e apresentam efeito letal para microorganismos não esporulados.

Desinfetante de uso geral. Produto para uso doméstico, em ambientes públicos ou privados; sobre superficies; em aparelhos sanitários, ralos, fossas. Classificação da ANVISA segundo a finalidade do produto.

Detergente. Produto formulado para promover o fenômeno da detergência, compreendendo um composto ativo (tensoativo) e componentes complementares (coadjuvantes, sinergistas, aditivos e produtos auxiliares). Definição da ANVISA.

Dual bed tube: Tubo de leito duplo ou de duas seç̧ões. Cartucho de amostragem de ar, utilizado quando há possibilidade de perda de material da amostra de ar por saturação do elemento coletor (breakthrough).

Esporo. Forma de resistência e disseminação produzida por bactérias ou fungos; sobrevive em condições ambientais drásticas como temperatura alta, presença de agentes químicos ou físicos e ambientes secos. Apresenta membrana/capa resistente. 
Formulação. Combinação de diversos ingredientes projetada para fazer com que o produto seja útil e efetivo segundo seu propósito; a forma em que os usuários adquirem a maioria dos produtos de limpeza.

Fungo: Organismo unicelular ou pluricelular. São classificados em bolores e leveduras. Os bolores sobrevivem em ambientes que normalmente são intoleráveis para as bactérias.

Gram-negativo. Diz-se das bactérias que se descoram e tingem com 0 corante de contraste quando se trata com a técnica de identificação de Gram.

Hidrocarbonetos. Substâncias formadas unicamente por carbono e hidrogênio. Conhecem-se centenas de milhares de combinações moleculares de carbono e hidrogênio. São os constituintes básicos de todas as substâncias orgânicas. As fontes mais importantes de hidrocarbonetos para a indústria química são: petróleo, gás natural e carvão.

Hidrótopo. Composto químico que tem a propriedade de aumentar a solubilidade em água de várias substâncias orgânicas pouco solúveis neste meio.

Ingrediente Ativo. (Al, Active Ingredient). $E$ a parte ativa presente numa formulação do produto de limpeza, ou seja, a substância que dá o efeito/benefício desejado. Princípio ativo. Linguagem comum do setor de produtos de limpeza e afins, assim como, ativo.

Mercado Doméstico. Produtos para a limpeza e cuidado da casa.

Mercado Institucional. Produtos para limpeza e cuidado de hotéis, escritórios, restaurantes e outros ambientes de uso coletivo.

Micela. Partícula de uma solução coloidal, constituída por uma partícula da substância em estado coloidal cercada por um conjunto de ions. Estas partículas da fase dispersa podem ter dimensōes que variam, aproximadamente, entre $5 \times 10^{-5} \mathrm{~cm}$ e $10^{-7} \mathrm{~cm}$. Ver também, colóide.

Micobactéria. (Mycobacterium). Gênero de microorganismo pertencente à familia mycobacteriacea, ordem Actinomycetales, que aparecem como 
bacilos delgados gram-positivos e se caracterizam por sua resistência ácido-álcool. Ex.: O bacilo que produz a tuberculose.

Microorganismo. Organismo microscópico pertencente ao reino vegetal ou animal.Ex.: Bactérias, fungos, leveduras e vírus, etc., que inclui mas não se limita a espécies de importância para a Saúde Pública. $O$ mesmo que micróbio.

Portaria. Documento de ato administrativo de qualquer autoridade pública, que contém instruções acerca da aplicação de leis ou regulamentos, recomendações de caráter geral, normas de execução de serviço, nomeações, demissões, punições, ou qualquer outra determinação de sua competência.

Princípio ativo. Ver Ingrediente ativo.

Produto Saneante Domissanitário. Substância ou preparação destinada à limpeza, desodorização, higienização, desinfecção ou desinfestação domiciliares, de ambientes coletivos ou públicos ou no tratamento de água para utilização por quaisquer pessoas para fins domésticos ou para aplicação, manipulação por pessoas ou entidades especializadas para fins profissionais (Ministério da Saúde, 1988); são mais conhecidos como produtos de limpeza; são denominados saneantes domissanitários pela ANVISA e simplificadamente saneantes, pelos profissionais ligados à indústria.

Pressão de Vapor. Pressão exercida pelo vapor se este se mantiver confinado sobre seu líquido de modo que possa acumular-se sobre si mesmo (mantendo a temperatura constante) a pressão de vapor se aproxima a um limite fixo chamado de pressão de vapor saturada, que dependerá da temperatura e do líquido. Quanto maior a pressão de vapor, maior a facilidade com que o material irá evaporar. É medida em $\mathrm{mmHg}$ ou $\mathrm{Pa}$ (pascal).

Produtos 18I. (Insdustrial and Institutiona). Produtos Institucionais e Industriais. Aqueles que, por sua forma de apresentação, toxicidade ou uso 
especifico, devem ser aplicados ou manipulados exclusivamente por pessoa ou empresa especializada. Não são encontrados em supermercados, mas em distribuidores autorizados ou adquiridos diretamente dos fabricantes. Normalmente são vendidos acondicionados em embalagens grandes $(5 a 50 \mathrm{Kg}$ ), podem ser mais concentrados dos que os produtos domésticos e também, apresentar maior risco à saúde. Definião ANVISA complementada.

Resistência. Resistência de microorganismos à substâncias químicas de ação antimicrobiana. Perda da susceptibilidade de uma dada cepa (linhagem) devido ao uso incorreto dos princípios ativos. No caso de desinfetantes: tempo de exposição insuficiente, temperatura inadequada, contato insuficiente (zonas mortas, "sombra" de uma célula sobre a outra) e formação de biofilmes. No caso de conservantes: dosagem subletal, $\mathrm{pH}$ inadequado, solubilidade/distribuição, inativação da substância ativa, incompatibilidade com outros componentes de fórmula do produto e temperatura inadequada. Uma revisão da literatura indica que o mecanismo de resistência é um assunto complexo e apenas parcialmente compreendido e que a capa dos esporos tem um importante papel neste mecanismo.

Resolução. Mecanismo legal/regulatório que possibilita que uma lei ou norma em vigor, seja colocada em prática/executada pelo estabelecimento de critérios, procedimentos ou padrões.

Rodenticidas. (Rodenticides). Agentes químicos, físicos ou biológicos utilizados intencionalmente para produzir a morte de roedores prejudiciais ao homem e seus cultivos.

Sanitização. Conjunto de procedimentos utilizados na indústria de produtos de limpeza e outros, tais como alimentos e cosméticos, e que visam à manutenção das condições de higiene indispensáveis à obtenção de produtos de primeira qualidade. Faz parte das Boas Práticas de Fabricação (ver BPF). Envolve higienização de superfícies com produtos detergentes e desinfetantes. O tipo, a concentração e o tempo de ação do(s) produto(s) 
utilizado(s) são de grande importância para a eficácia da sanitização, assim como o tipo de superfície.

Sílica-gel. Material adsorvente regenerativo consistindo de sílica amorfa $\left(\mathrm{SiO}_{2}\right)$ com grupos $\mathrm{OH}$ na superfície, tornando-a um material polar e aumentando as reações de superfície.

Síndrome. Etiologia não específica, no sentido que as manifestações clínicas podem ser provocadas por diferentes microorganismos.

Surfactante. Ver tensoativo.

Tensoativo. Substância química de propriedade emulsificante, umectante, dispersante e etc. Atua modificando superfícies, através da redução da tensão superficial. O mesmo que surfactante. É a matéria-prima para a fabricação de detergentes. Podem ser, basicamente, de três tipos:

- tensoativo aniônico: agente tensoativo possuindo um ou mais grupamentos funcionais que, ao se ionizar em solução aquosa, fornece ions orgânicos carregados negativamente e que são responsáveis pela tensoatividade.

- tensoativo catiônico: agente tensoativo possuindo um ou mais grupamentos funcionais que, ao se ionizar em solução aquosa, fornece ions orgânicos carregados positivamente e que são responsáveis pela tensoatividade.

- tensoativo não-iônico: agente tensoativo que não fornece íons em solução aquosa e cuja solubilidade em água se deve à presença, nas suas moléculas, de grupos funcionais, que possuem forte afinidade pela água.

Teratogênese. Introdução de malformaçōes e outros defeitos congênitos e/ou malformações durante o período pré-natal.

Teratogênico. Capaz de produzir defeitos congênitos e/ou malformações durante o período pré-natal. 
TLV. Threshold Limit Value. É estabelecido pela ACGIH como a concentração de uma substância no ar do ambiente de trabalho, que pode ser inalada pela maioria dos individuos, 8 horas por dia, 5 dias por semana durante toda a vida laboral sem a ocorrência de efeitos adversos. A ACGIH expressa os TLV de três maneiras:

- TLV-TWA - a concentração média ponderada pelo tempo permissível para uma jornada diária de 8 horas e de $\mathbf{4 0}$ horas semanais.

- TLV-STEL (Short Term Exposute Limit) - a concentração de exposição de curta duração ou máxima concentração para um período contínuo de exposição de 15 minutos (no máximo de quatro períodos por dia, com no mínimo 60 minutos entre períodos de exposição e desde que o TLVTWA não seja excedido).

- TLV-C (Ceiling) - a concentração teto. A concentração que não deve ser excedida mesmo que instantaneamente.

TWA. Time-weighted Average. Média ponderada em relação ao tempo que permite a exposição acima do limite permissivel para exposição ocupacional sempre e quando esteja compensada com periodos equivalentes sob 0 nivel durante a jornada ou o turno de trabalho. Recomendado para substâncias com efeito a longo prazo como poeiras, metais e solventes. São preconizados pela associação dos higienistas industriais dos EUA (American Conference of Govemmental Industrial Hygienists); atualizados anualmente e baseados nas melhores informações científicas disponiveis. São mundialmente tomados como referência. Segundo a NR-9, os limites da ACGIH devem ser utilizados na ausência de limites na NR-15.

Valor do produto. Conceito de Marketing. É a razão entre a qualidade e o custo do produto. Quando a razão é igual a 1, significa que o custo é justo em relação à qualidade proporcionada pelo produto. Produtos de alto valor (maior do que 1) oferecem qualidade superior ao preço considerado justo. Para o consumidor, preço justo pode ser definido como o que ele está disposto a pagar pelo produto que the proporciona a qualidade que the satisfaz. 
Vírus. Seres microscópicos formados por material genético e cápsula. São sempre parasitas de outras células. Não são sensiveis a antibióticos. 